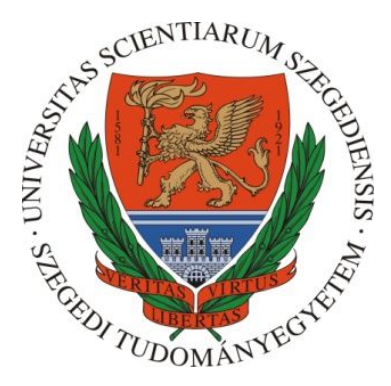

\title{
Termikus reakciók vizsgálata arany nanorészecskéket tartalmazó katalizátorokon
}

\author{
Ph.D. értekezés
}

\section{Gazsi Andrea}

\author{
Témavezető: \\ Prof. Solymosi Frigyes \\ professzor emeritus
}

Kémia Doktori Iskola

\author{
Szegedi Tudományegyetem \\ Természettudományi és Informatikai Kar \\ Fizikai Kémiai és Anyagtudományi Tanszék
}




\section{TARTALOMJEGYZÉK}

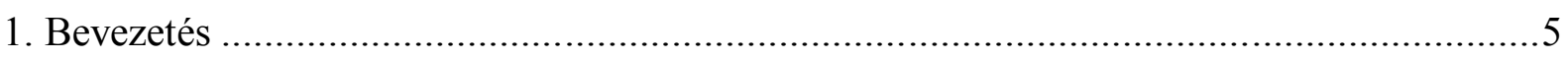

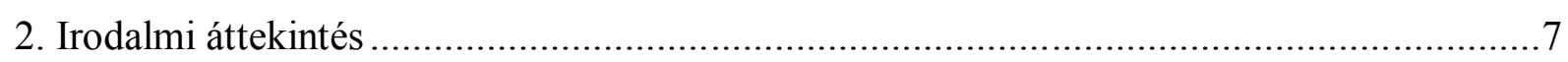

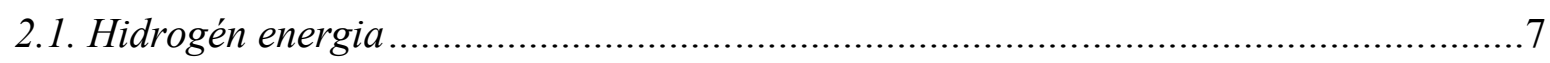

2.2. Az arany katalitikus tulajdonságai ................................................................. 8

2.3. Szerves vegyületek katalitikus bontása (metanol, etanol, DME, hangyasav) ................9

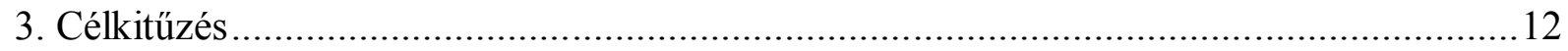

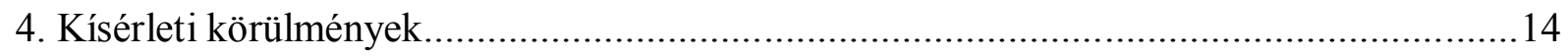

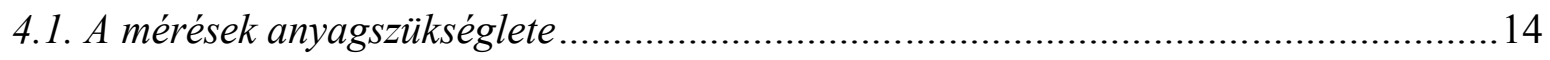

4.1.1. A katalizátor elóállitásához használt anyagok ................................................. 14

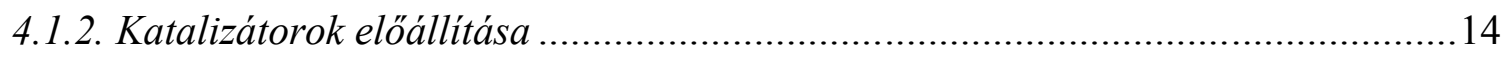

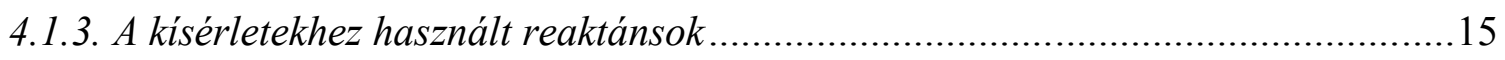

4.2. Vizsgálati módszerek ................................................................................. 16

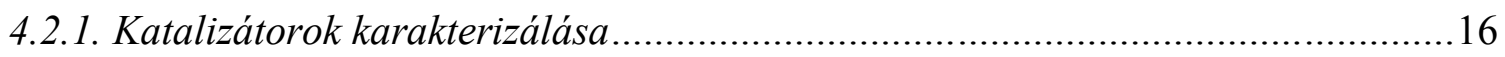

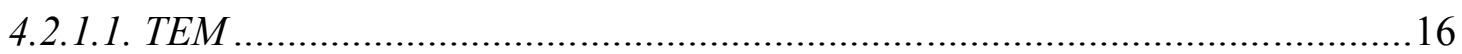

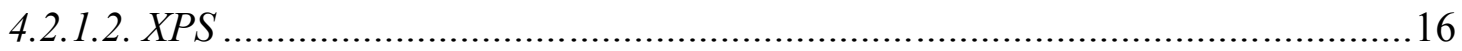

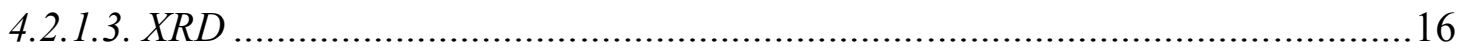

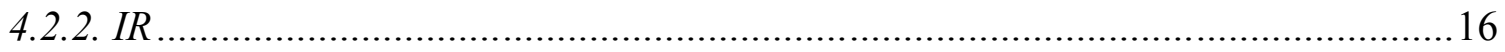

4.2.3. Gáz-kromatográffal vizsgált reakciók ...................................................... 18

4.2.3.1. Termikus mérések .................................................................................. 18

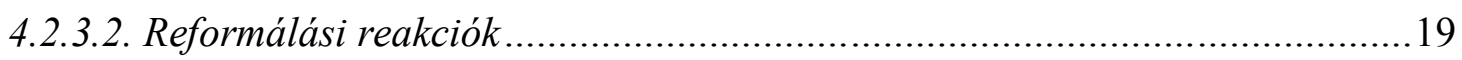

4.2.3.3. Hömérsékletprogramozott deszorpció TPD ................................................20

4.2.3.4. Hömérsékletprogramozott redukció TPR .................................................20

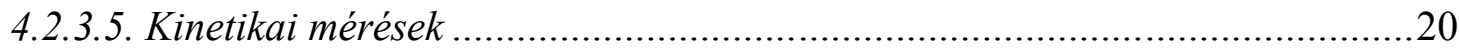

4.2.3.5.1. A reakció hömérsékletfüggése (aktiválási energia meghatározás) ..........20

4.2.3.5.2. A reakció nyomásfüggése (rendüség meghatározás) .............................20

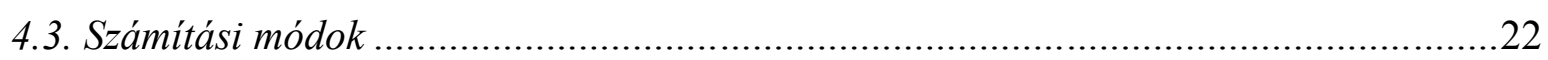

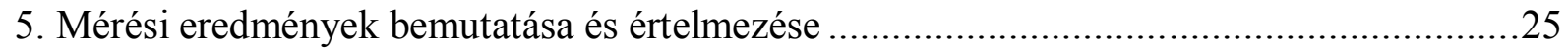

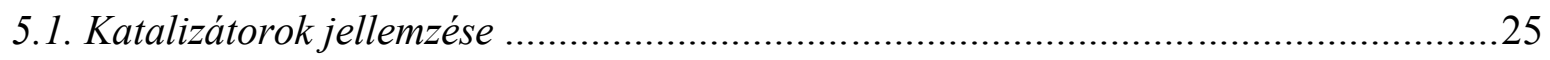

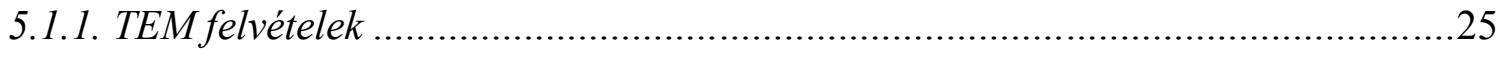

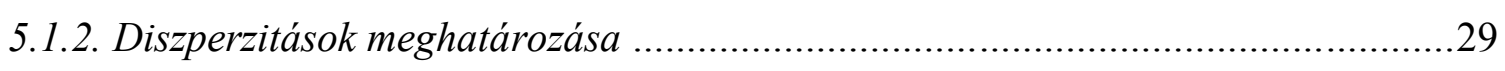

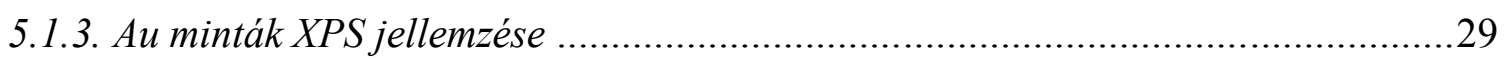

5.2. Reaktánsok katalitikus bontása és reformálása .................................................... 31

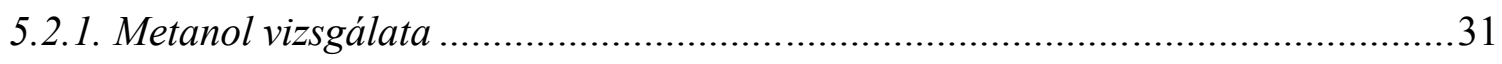




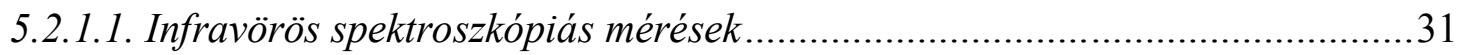

5.2.1.2. Hömérséklet programozott deszorpciós mérések (TPD) ................................33

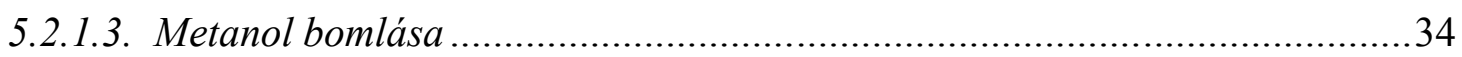

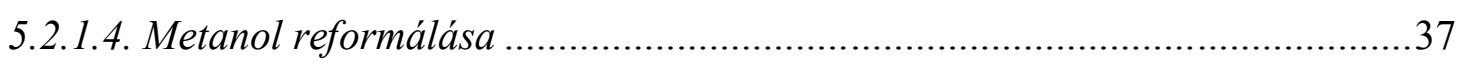

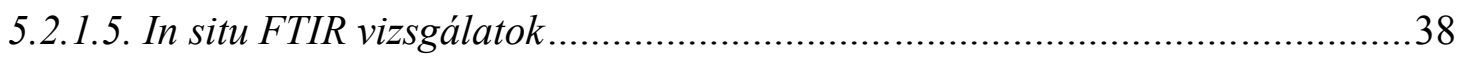

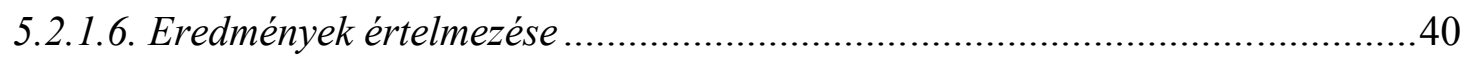

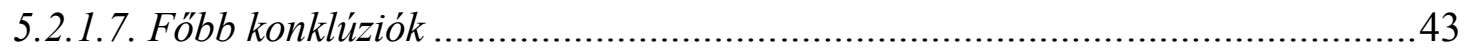

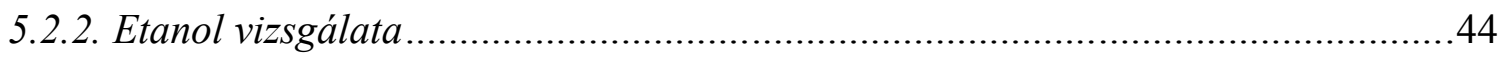

5.2.2.1. Infravörös spektroszkópiás mérések ............................................................44

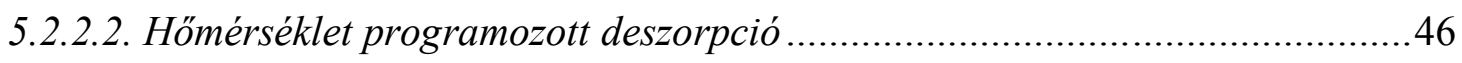

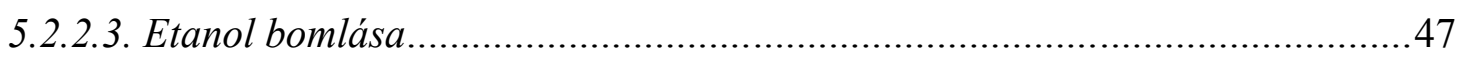

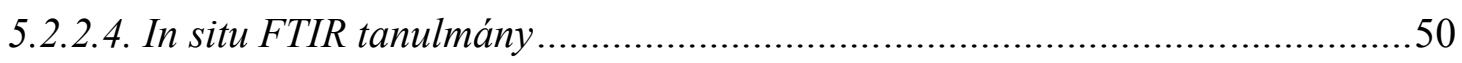

5.2.2.5. A katalizátorok XPS vizsgálata a reakció folyamán ....................................51

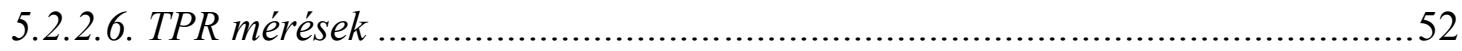

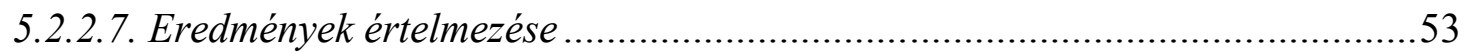

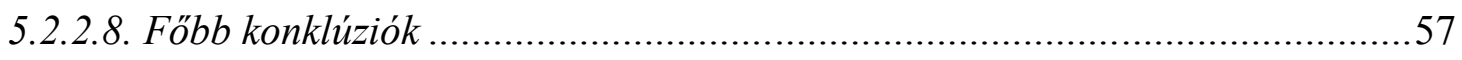

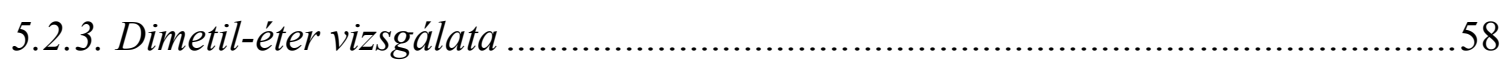

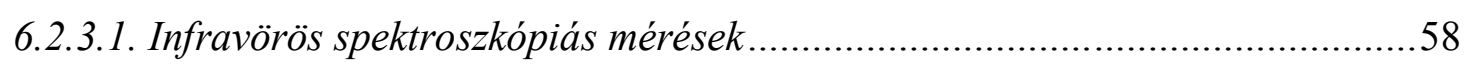

5.2.3.2. Hömérséklet programozott deszorpció .....................................................6 60

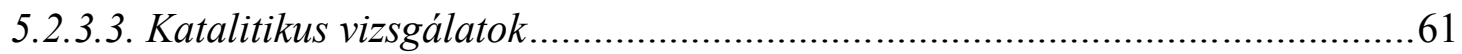

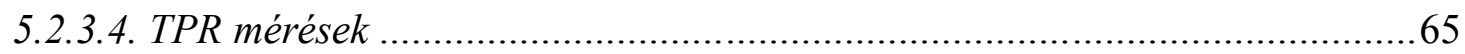

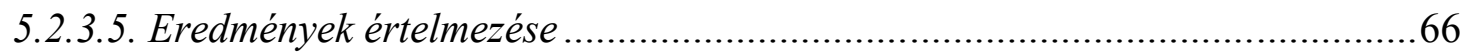

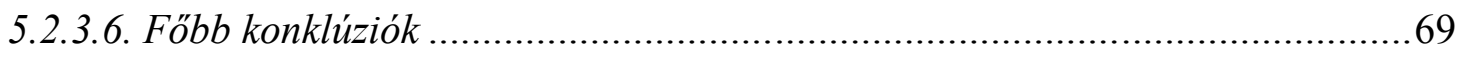

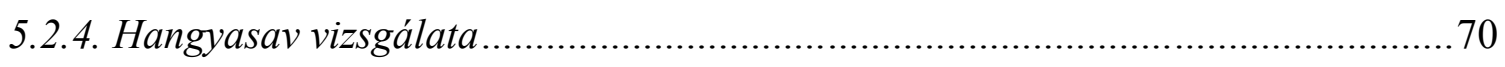

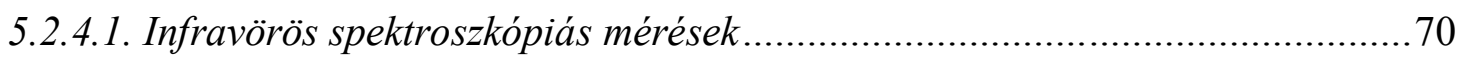

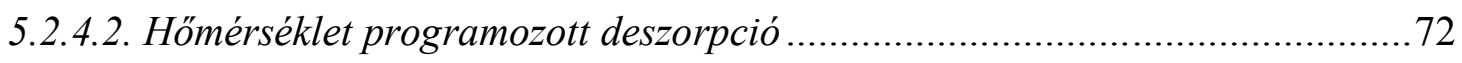

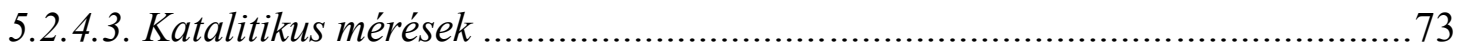

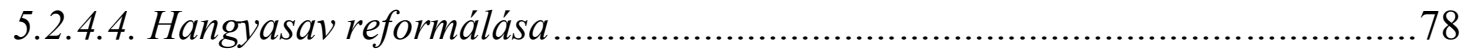

5.2.4.5. Eredmények értelmezése ................................................................... 79

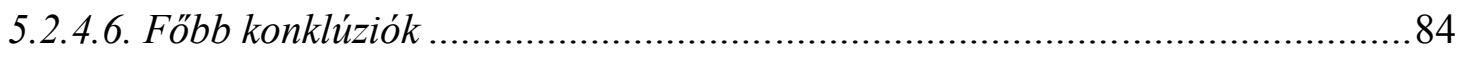

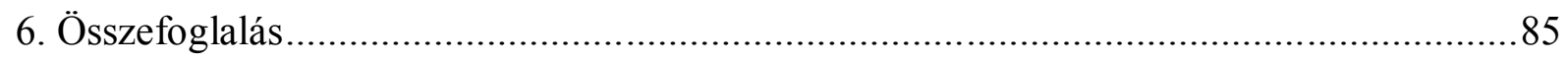

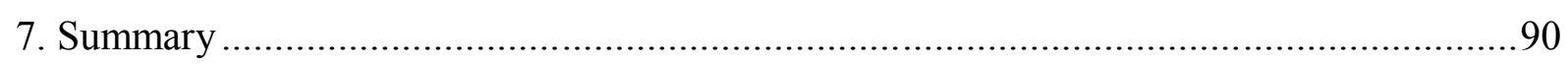

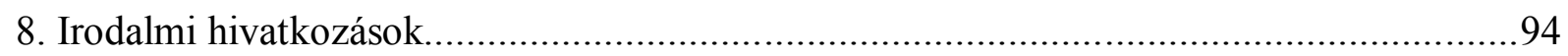

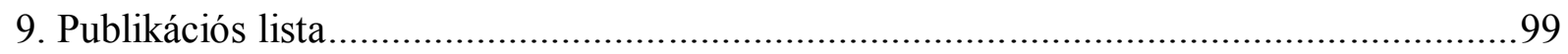

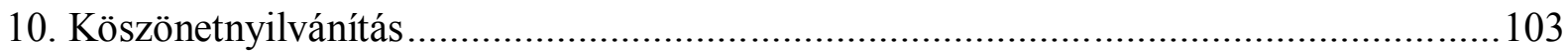


Alkalmazott rövidítések, jelölések jegyzéke

ICP-AES: induktív csatolású plazma atomemissziós spektrometria

DME: dimetil-éter

TEM: transzmissziós elektronmikroszkópia

XPS: röntgenfotoelektron spektroszkópia

XRD: röntgendiffrakció

BET: Brunauer, Emmett és Teller

IR: infravörös spektroszkópia

FTIR: Fourier transzformációs infravörös spektroszkópia

GC: gáz-kromatográf

GC-MS: gáz-kromatográffal kombinált tömegspektroszkópia

TC: vezetőképességi detektor

FID: lángionizációs detektor

TPR: hőmérséklet programozott redukció

TPD: hőmérséklet programozott deszorpció

$\mathrm{T}_{\mathrm{P}}$ : csúcshőmérséklet

$\mathrm{T}_{\mathrm{R}}$ : redukció hőmérséklete

TOF: turnover frequency

$E_{a}$ : aktiválási energia 


\section{Bevezetés}

Míg a 19. században a heterogén katalízis inkább csak kuriózumnak számított, mára olyan nagyságúra nőtte ki magát, hogy nélkülözhetetlenné vált a mindennapi életünkben. Nincs olyan ipari folyamat, amelyben ne kapna jelentős szerepet a katalízis. Számos észrevétel, kísérlet és szabadalom született a katalizátorok hatásinak tanulmányozása során, amelyet elsőként 1836-ban J. J. Berzelius az alábbiak szerint összegzett:

„Ezért ezt az anyagok katalitikus erejének fogom nevezni, és a bomlást, amely ennek az erőnek a következtében létrejön, katalízisnek [...]. A katalitikus erő ténylegesen azt jelenti, hogy az anyagok puszta jelenlétük és nem saját affinitásuk következtében képesek az adott hőmérsékleten szunnyadó affinitásokat feléleszteni.” A tudomány fejlődésének következtében a definíció mai megfogalmazása: A katalizátor olyan anyag, amely megnöveli valamely kémiai rendszer egyensúlyi helyzetéhez vezető sebességet anélkül, hogy a folyamatban elhasználódna ${ }^{1}$.

A technológia fejlődésének egyik elengedhetetlen lépése a katalizátorok alkalmazása és azok folyamatos fejlesztése. Pár évtizede az ipari folyamatok fó célja a lehető legmagasabb konverzió elérése volt, míg ma a katalízis legfontosabb feladata a magas szelektivitás; hiszen sok esetben a képződött melléktermékeknek számos negatív hatása lehet: nem költséghatékony a képződésük, ha nem használhatók fel egyéb célra, elválasztásuk a fö terméktől további nehézséget okoz, jelenlétük az alkalmazott katalizátor aktivitásának csökkenéséhez vagy lemérgeződéséhez vezethet valamint a környezetre is káros hatással lehet. A jelen kor ipari katalizátorokkal szemben támasztott követelményei, hogy nagy hatásfokkal müködjenek, jelentősen növeljék a kívánt reakció sebességét, legyenek olcsók és hosszabb idő után se veszítsék el aktivitásukat.

A katalizátorok ezen tulajdonságainak felerősítésében alapvető szerepet játszik az ún. hordozók alkalmazása. A hordozók az aktív részecskék váz-, kötő- és stabilizáló anyagai. Katalitikus aktivitásuk általában kicsi (bár jelenlétük befolyásolhatja a katalitikus tulajdonságokat), mennyiségük az aktív komponensénél lényegesen nagyobb. Alkalmazásuknak legfőbb oka a katalitikus hatással rendelkező részecskék felületének, hozzáférhetőségének növelése a reaktánsok számára. A hordozó befolyásolhatja a katalizátor aktivitását, szelektivitását, élettartamát és csökkentheti a dezaktiválódás valamint a részecskék aggregációjának mértékét. 
Az a felfedezés, hogy az anyagok a nanoméretü tartományban megváltoztatják a tulajdonságaikat, a katalízis területén is új utat nyitott a kutatók számára. A nanorészecskék egyik legfontosabb tulajdonsága, hogy a méret csökkenésével nagymértékben megnő a szilárd részecskék fajlagos felülete, vagyis a felület/térfogat arányuk, ami a katalitikus reakcióknál azt eredményezi, hogy megnövekszik az aktív helyek hozzáférhetősége, ezáltal a katalitikus aktivitás tovább fokozható. A nagyobb fémrészecskéket tartalmazó katalizátorokkal ellentétben a nanorészecskéket tartalmazó hordozós katalizátorok esetében a részecskék és a hordozó között kialakulhat kölcsönhatás, amely pozitív hatással lehet a katalitikus aktivitás és a szelektivitás mértékére.

A nanorészecskék kiemelkedő katalitikus tulajdonsága talán az arany esetében a legszembetűnőbb, hiszen míg tömbi fázisban teljesen inertként viselkedik, viszont ha a részecskék a nano mérettartományba esnek, jelentős katalitikus aktivitást mutatnak; különösen, ha a méretük 2-10 nm és $\mathrm{TiO}_{2}, \mathrm{Fe}_{2} \mathrm{O}_{3}$, stb. hordozó felületére lettek felvíve ${ }^{2}$.

Nem kétséges, hogy a 21. század egyik kihívása a hordozós, egyforma méretü, jól szabályozható fém nanorészecskéket tartalmazó katalizátorok előállítása, jellemzése és katalitikus tulajdonságaik megismerése. 


\section{Irodalmi áttekintés}

\subsection{Hidrogén energia}

Az univerzumban a legmagasabb arányban előforduló elem a hidrogén. Már több mint 100 éve használja a vegyipar, leginkább az ammóniagyártás és kőolaj-finomítás céljára, de más vegyipari területeken is alkalmazzák. Az utóbbi időszakban a hidrogénre, mint alternatív energiaforrásra is tekint a világ.

A kőolajszármazékok égetésével, amelyekből az energiafelhasználásunk legnagyobb részét fedezzük, számos levegőszennyező anyagot termelünk, többek között jelentős mennyiségü üvegház gázokat. Ezzel szemben egy hidrogénnel müködő üzemanyagcella energiatermeléskor csak vizet hoz létre melléktermékként.

A jelenleg használt hidrogén elöállítási módok azonban még nem környezetbarát technológián alapulnak. Ilyen például a fosszilis energiahordozókból való előállítás. A teljes hidrogén-előállításon belül is jelentős mennyiséget képvisel a földgázból, pontosabban metánból való előállítási mód. Emellett számottevő még a kőolajból, valamint szénből történő előállítás. Ezek közös jellemzője, hogy igen jelentős szén-dioxid kibocsátással járnak. Ezeknek a hagyományos előállítási módoknak előnye, hogy jelenleg ezek a legolcsóbbak.

Hidrogén előállításra kis mértékben hidrolízist is alkalmaznak, azaz vízbontást. A módszer hátránya, hogy igen nagy az energia igénye, így kérdéses, hogy megtérül-e a befektetett energia, vagyis az ilyen módon elöállított hidrogénböl származó energia mennyiben fedezi ezt. Folynak kutatások korszerü radiokémiai, bakteriológiai és mesterséges fotoszintézis felhasználásának lehetőségeit keresve a gazdaságos hidrogénelőáálításának céljából. Ezen kutatások együttes elönye, hogy a környezetünk védelmére irányulnak.

A hidrogén előállítása mellett a fö gond a hidrogén szállításával, tárolásával és a biztonsággal van. Erre a célra ma még a cseppfolyósított hidrogén a legelterjettebb. Olyan kis szénatomszámú vegyületek bontása jelentheti az egyik megoldást, amelyekben a hidrogén/szén arány nagy és lehetőség szerint nem tartalmaznak szén-szén kötést. Ezen kívül a könnyebb kezelhetőség miatt folyékony halmazállapotúak, hogy könnyen szállíthatóak legyenek. Ilyen lehet például a metanol, etanol, hangyasav, amelyek katalitikus bontása jó lehetőséget kínál a hidrogén előállítására. Ezeknek a reakcióknak kitünő katalizátorai lehetnek a drága platina fémek. Ezen terület feltérképezésében kutatócsoportunk is jelentős szerepet játszott a közelmúltban ${ }^{3,4}$; de már a 80 -as években is végeztek kutatásokat ebben az irányban ${ }^{5}$. 
Nemrégiben laboratóriumunkban kimutattuk azt is, hogy a $\mathrm{MoO}_{3}$-ból elöállított $\mathrm{Mo}_{2} \mathrm{C}$ több falú szén nanocső és aktivált szén norit hordozón is aktív és stabilis katalizátor az oxigén tartalmú vegyületek bomlásában és reformálásában ${ }^{6}$.

\subsection{Az arany katalitikus tulajdonságai}

Az aranyat, mint fémet már az újkőkorban ismerte az emberiség és az ókortól kezdék el fizetőeszközként használni, elsőként az egyiptomiak. Felhasználási területét jelentősen befolyásolta, hogy nagyon sokáig inert anyagnak gondolták, hiszen más anyagokkal szinte nem reagál, nagymértékben ellenáll a korróziónak és savakban nem oldódik. Így érthető, hogy a fő felhasználásának jelentős részében értékméröként alkalmazták (fizetőeszköz, ékszerek).

Nagyon nagyrészt köszönhető Haruta úttörő munkásságának, hogy drámainan megnőtt az érdeklődés az arany katalitikus erejének tanulmányozása iránt is. Ezt az elmúlt 20-25 évben az arany tartalmú katalizátorok vizsgálatáról szóló publikációk számának exponenciális növekedése is tükröz. Azonban a nanoméretü Au részecskék kiemelkedő aktivitásának értelmezése még mindig nem teljes. Az aktív arany katalizátorokat csak nagyon jól szabályozott körülmények között lehetséges elöállítani, így nem meglepő, hogy az arany katalitikus tulajdonságának felismerésére ilyen sokáig kellett várni. Így joggal tekinthetünk az aranyra, mint egy új katalizátorra.

Haruta munkásságát megelőzően 1906-ban figyelték meg először az arany katalitikus tulajdonaságát, amikor Bone a hidrogén oxidációját vizsgálta egy aranylemezen ${ }^{7}$. Azomban az első ténylegesen katalizátorként történő alkalmazása 1925-ben a szén-monoxid oxidációs reakciójában használták ${ }^{8}$. Ezt követően az 1950-es 60-as években felismerték az arany hidrogénező tulajdonságát is ${ }^{9,10}$.

A következő nagy lépés az arany katalízis területén a 70-es években volt. Kimutatták, hogy az aranyat alumínium-oxid és szilícium-oxid hordozók felületére felvíve aktívan katalizálja az alkének hidrogénezését $373 \mathrm{~K}-\mathrm{en}^{11}$.

Az arany igazi katalitikus alkalmazása akkor kezdődött, amikor felfedezték, hogy mintegy 2-10 nm méretű nanorészecskék formájában kiemelkedő aktivitást mutat ${ }^{12}$. A kilencvenes évek elején Haruta azt tapasztalta, hogy a CO oxidáció szobahőmérséklet alatt is lejátszódik, ha oxid felületen diszpergált arany nanorészecskéket használunk katalizátorként. Haruta a $\mathrm{CO}$ oxidációját vizsgálva arany/ $\mathrm{TiO}_{2}$-on víz jelenlétében kimutatta, hogy a 
reakciósebességet akár tízszeresére is lehet növelni, de egy bizonyos határon túl a víz mennyisége már elnyomja a reakciót, mert adszorbeálódik a katalizátor felületén ${ }^{13}$.

$\mathrm{Az}$ aranykatalízis kutatása előtt álló egyik legnagyobb kihívás a stabilis, hosszú élettartamú katalizátorok előállítása, ami előfeltétele az ipari alkalmazásnak. Az állandó aktivitás egyik kulcsa az arany részecskék méretének stabilizációja, az aggregáció megakadályozása.

Kétségtelenül a jövő technológiáját vetíti elénk az arany nanorészecskék alkalmazása. Megemlítendő például a víz-gáz reakció (amely a tüzelőanyag-celláknál is szerepet játszik), ami a megfelelő arany katalizátoron a szénmonoxidot távolítja el a hidrogéngázból, mint a tüzelőanyag-cella egyik komponenséből. A reakció kisebb hőmérsékleten gazdaságosabban történik, mint a ma ismert katalizátorokon. Az arany nanorészecske hatékony katalizátora nyomnyi szénmonoxid eltávolításának is hidrogéngázból. Ez azért fontos, mert a szénmonoxid erősen mérgezi a tüzelőanyag-cellában elhelyezett katalizátort. Ezen kívül az aranykatalizátor a dízel motorok utóégető katalizátoraként is használható, amelyet igen kiterjedten kutatnak.

Számos fontos reakciók lejátszódását katalizálják az arany nanorészecskék: szénhidrogének szelektív és nem szelektív oxidációja, metanol szintézise szén-monoxid vagy szén-dioxid hidrogénezésével valamint a víz-gáz reakció.

$\mathrm{Az}$ arany két oxidja ismeretes, az arany monoxid vagy auro-oxid, $\mathrm{Au}_{2} \mathrm{O}$, amely már $423 \mathrm{~K}$-en, illetve az arany trioxid vagy auri-oxid, $\mathrm{Au}_{2} \mathrm{O}_{3}$, amely $523 \mathrm{~K}$-en aranyra és oxigénre bomlik.

\subsection{Szerves vegyületek katalitikus bontása (metanol, etanol, DME, hangyasav)}

A hidrogén energia terjeszkedésére közvetlenül felhasználására üzemanyagként vagy közvetve üzemanyag cellákban metanol használata lehet egy megoldás, mert abban magas a hidrogén/szén arány, nem tartalmaz szén-szén kötést, és folyadékként könnyen szállítható. Az a feladat és a kihívás a katalízis számára, hogy fejlesszenek egy hatékony és stabil katalizátort a hidrogéntermelő metanol reakció számára. Az elektromos járművek tiszta hidrogén üzemanyagra és a kapacitás mértékének javítására való igénye indította el a nagyfokú érdeklődést a hidrogéntermelés iránt. Először a platina-csoport fémeit használták az alkoholok bontásánál és reformálásánál ${ }^{14-20}$. A metanol bomlása gyakorlatilag csak $\mathrm{H}_{2}$-t és CO-t 
eredményezett, nagyon alacsony egyéb vegyület tartalommal (melléktermék), de a CO teljes kiküszöbölését nem tudták elérni ${ }^{15}$. Csoportunkban folyó kutatásaink során nemrég azt találtuk, hogy a $\mathrm{Mo}_{2} \mathrm{C}$, amelyet $\mathrm{MoO}_{3}$ reakciójával készítettünk többfalú szén-nanocsővel és aktivált norittal, szintén egy nagyszerü katalizátora az oxigén tartalmú vegyületek bomlásának és reformálásának, úgymint metanol ${ }^{21,22}$, etanol ${ }^{23}$ és dimetil-éter ${ }^{24}$. Egyik fontos tulajdonsága a $\mathrm{Mo}_{2} \mathrm{C} / \mathrm{C}$-nak a magas stabilitása, ami azt jelenti, hogy a konverzió és a hidrogénképződés csak kis százalékban csökken 30-75 óra 673-773 K-es reakció után.

Tovább vizsgálódva más aktív anyagok felkutatására az alkoholok bomlásában azt találták, hogy az arany egy hatékony anyag számos technológiailag fontos reakciónál, ez az elmúlt két évtizedben a katalitikus kutatások egyik legmeglepőbb eredménye. Haruta úttörő munkásságát követve $\mathrm{e}^{2,12}$ az arany katalizátorként való alkalmazása fokozatosan növekvő figyelmet $\operatorname{kap}^{25-27}$. Figyelemre méltó jelleget ad az aranynak a részecskeméretétől függü nagy szelektivitása $^{2,23-25,28-30}$. Ezt a viselkedését alkalmazták a $\mathrm{CO}$ szelektív oxidációjánál $\mathrm{H}_{2}$ mellett ${ }^{25-27}$. A hordozós arany katalizátor is magas aktivitást mutatott a $\mathrm{NO}+\mathrm{CO}$ reakcióban hasonlóan a hordozós Rh-katalizátorokhoz ${ }^{31,32}$. Viszont az arany katalizátorokon alkoholból képződő hidrogén előállításáról csak kevés publikáció jelent meg ${ }^{33-37}$.

A metanolhoz hasonlóan a magas $\mathrm{H} / \mathrm{C}$ arány miatt a hidrogén képződés szempontjából a metán is jó kiindulási anyag lehet ${ }^{38}$. A hordozós Pt fémek hatékonyan katalizálják a metán bontását, de a szén lerakódás a katalizátorokon korai dezaktiválódáshoz vezet ${ }^{39-45}$. A H/C arány hasonló nagyságú a metanolban is, de az előállítása igényel hidrogént és a toxikus tulajdonságát is figyelembe kell venni. Ezzel szemben az etanol előnye, hogy előállítható fermentációs növényekből és a biomaszából származó vegyületekből valamint a tárolása és szállítása is viszonylag egyszerü. Tehát az etanol könnyen elérhető, viszont bomlása során számos különböző vegyület képződik melléktermékként és a molekulájában lévő C-C kötés felszakításához aktív katalizátor használata és nagyobb energia szükséges ${ }^{14}$. A képződött melléktermékek dezaktiváló hatása a Pt fémekre jelentős hátrányt jelent ${ }^{46-48}$. Hutchings ${ }^{49}$ ezen területen végzett munkája is jelezte, hogy a hordozott $\mathrm{Au}$ katalizátorok szokatlanul magas aktivitást mutatnak a szén-monoxid oxidációjában és számos más reakciókban. Ezek az eredmények előremutattak, hogy várhatóan az arany nanorészecskék jól alkalmazhatóak lesznek az alkoholok azon reakcióiban, amikor a szén atom(ok) oxidációja és a hidrogén képződése a cél. A metanol arany katalizátoron történő bomlásával foglalkozó tanulmányok mellett ${ }^{33-37,50-51}$ csak néhány közlemény jelent meg, amely etanol rekcióit vizsgálja ezeken a katalizátorokon. Idriss ${ }^{52}$ tanulmányozta az etanol oxidációját $\mathrm{Au} / \mathrm{CeO}_{2}$-on, valamint Guan és Hensen $^{53}$ a közelmúltban vizsgálták meg az etanol dehidrogénezését $\mathrm{Au}$ nanorészecskéket 
tartalmazó különböző $\mathrm{SiO}_{2}$ hordozókon, ahol az arany részecskék méretének nagy befolyásoló hatását figyelték meg. Egyik fontos eredményük volt, hogy oxigén jelenlétében az $\mathrm{Au} / \mathrm{SiO}_{2}$ aktivitása jelentősen fokozódott.

Növekvő érdeklődés figyelhető meg a dimetil-éter használatában (DME), amely nagy mennyiségü hidrogént tartalmaz, és úgy tünik alkalmas vegyület lehet hidrogénforrásnak. A DME számos előnyös tulajdonsággal és alkalmazhatósággal rendelkezik. Úgy ítélik meg, hogy alkalmas lehet a gázolaj helyett alternatív üzemanyagként, az égése sokkal kevesebb szennyező anyag kibocsátást eredményez ${ }^{54-56}$. Az elmúlt évtizedben a DME számos katalitikus reakcióiját tanulmányozták már, égés, dehidrogénezés, hidrolízis, szelektív oxidáció, CH-ekké történő alakítás $^{57}$ és aromatizációs ${ }^{58,59}$. Mivel nem toxikus, így hidrogénhordozóként használata előnyösebb lehet, mint a metanol. A DME hidrogénné történő bomlását és reformálását számos katalizátoron tanulmányozták már ${ }^{24,60-70}$. A leghatékonyabbnak a Pt fémek bizonyultak. Egy másik lehetséges alternatív megoldás, amely olcsóbb, de kevésbé aktív, az összetett katalizátorok alkalmazása. A DME-ből képződő hidrogén első lépésben a DME metanollá történő hidrolízisét igényli, ami egy magasabb $\mathrm{H}_{2}$ hozamhoz járul hozzá ${ }^{70}$. Ily módon tudjuk, hogy a norrit hordozós MoC katalizátor növeli a $\mathrm{H}_{2}$ termelést a DME bomlása során is ${ }^{24}$.

Némileg meglepő a $\mathrm{HCOOH}$ azon alkalmazása, hogy lehetséges $\mathrm{H}_{2}$ forrás üzemanyag cellákban is ${ }^{71,72}$, nagyon kevés figyelmet kapott, noha bomlási reakcióját széles körben alkalmazták az 1950 és 60-as években teszt reakcióként a fémek, ötvözetek és oxidok elektromos tulajdonságának szerepének heterogén katalitikus vizsgálatában ${ }^{73-78}$. Csoportunk kutatómunkája során nemrégiben bemutatta, hogy a $\mathrm{Mo}_{2} \mathrm{C}$ egy kiváló és stabil katalizátora a $\mathrm{CO}$ mentes $\mathrm{H}_{2}$ hangyasavból történő előállításának is ${ }^{79}$. A hangyasav folyadék fázisú bomlásának tanulmányozása közben Zhou ${ }^{80}$ megfigyelte, hogy Pd hozzáadása $\mathrm{Au} / \mathrm{C}$ és $\mathrm{Ag} / \mathrm{C}$ hez nagyon aktív és szelektív katalizátorokat eredményezett a $\mathrm{H}_{2}$ előállítására. Ojeda és Iglesia szemléltette, hogy $\mathrm{Au}$ nanorészecskéket tartalmazó $\mathrm{Al}_{2} \mathrm{O}_{3}$ és $\mathrm{TiO}_{2}$ használható in situ $\mathrm{H}_{2}$ forrás elóáálítására hangyasavból ${ }^{81}$. Ross ${ }^{82}$ felfedezte, hogy a $\mathrm{Pd} / \mathrm{C}$ aktívabb katalizátor, mint az $\mathrm{Au} / \mathrm{TiO}_{2}$ a hangyasav bomlásában és reformálásában. Ezen a katalizátoron 95-99\% szelektivitást ért el $400 \mathrm{~K}$ felett. Egy új, összehasonlító tanulmányban azt találtuk, hogy a szén norit hordozós $\mathrm{Pt}$ is hatékony katalizátor a hangyasav gőzfázisú bontásában $\mathrm{H}_{2}$ képződés szempontjából 95-99\% szelektivitással ${ }^{83}$. Teljesen $\mathrm{CO}$ mentes $\mathrm{H}_{2}$-t kaptunk a hangyasav reformálási reakciójában Ir/norit katalizátoron 383-473 K-en. Biztató eredményeket kaptak a hangyasav bomlását tanulmányozva különböző fém komplexeken oldat fázisban ${ }^{84-86}$ is. 


\section{Célkitűzés}

Napjaink legfontosabb feladatai közé tartozik a jövő alternatív energiaforrásainak felkutatása és ezek ipari felhasználásának kialakítása. Ahogy az előzményekből is kiderült, az egyik ilyen legkézenfekvőbb energiaforrás a hidrogén. Célunk tehát a hidrogén mint energiaforrás előállítása. Ehhez olyan kiindulási anyagokat választottunk, amelyekben a $\mathrm{C} / \mathrm{H}$ arány alacsony, mivel így nagyobb szelektivitást érhetünk el. Fontos szempont volt a reaktánsok kiválasztásánál még, hogy nagy mennyiségben rendelkezésre álljon vagy olcsó legyen az előállítása illetve a környezetre gyakorolt hatása ne legyen káros. Így a legfontosabb vegyületek, amelyek ezen szempontoknak megfelelnek a hangyasav, metanol, etanol és a dimetil-éter.

A hidrogén szelektivitás növelésének érdekében minden esetben arany katalizátort alkalmaztunk különböző hordozókra impregnálva. Mint már az eddigiekből is kiderült, az aranyat nagyon sokáig inert fémnek tartották. Ez az elgondolás Haruta felfedezése után lényegesen megváltozott, miszerint, ha az arany részecskék 2-10 nm nagyságrendbe esnek, akkor lényegesen megnő az arany katalitikus hatása.

Köztudott, hogy a hidrogén mellett melléktermékként képződött CO nagymértékben lemérgezi az alkalmazott katalizátort a katalizátor fém részecskéihez való adszorpciójával már nyomnyi mennyiségben is. Ez a tény nagy nehézséget okoz jelenleg is a katalízis kémia területén. Viszont már régebbi vizsgálatok is bizonyították, hogy az arany igen jól oxidálja a CO-t már szobahőmérséklet alatt is, így nagymértékben növelhető lehet a katalizátor stabilitása.

Ezen tények összessége vezetett ahhoz az elképzeléshez, hogy arany nanorészecskék oxidhordozóra való diszpergálásával olyan katalizátort kaphatunk, amelynek segítségével CO mentes hidrogént állíthatunk elő. Célunk a nanoméretű arany katalitikus vizsgálata volt termikus körülmények között $\mathrm{CeO}_{2}, \mathrm{Al}_{2} \mathrm{O}_{3}, \mathrm{MgO}, \mathrm{TiO}_{2}, \mathrm{SiO}_{2}, \mathrm{ZSM} 5$ valamint norit hordozókon a metanol, etanol, hangyasav, valamint a dimetil-éter bomlásánál a konverzió és a szelektivitás növelésének lehetőségeinek feltérképezésével.

A különböző vegyületek bomlásához, átalakulásához energia befektetésre van szükség, hiszen a folyamatban kémiai kötéseket kell szakítanunk. Ennek az energiának a csökkentésére több mód is létezik, pl. katalizátorok alkalmazása (amellyel nem csak az aktiválási energia csökkentése érhető el, hanem a szelektivitás nagyfokú növelése is). További lehetőség, ha nem hő formájában közöljük ezt az energiát a rendszerrel, hanem fény 
besugárzással. A fotokatalízis előnye, hogy a reakciók már szobahőmérsékleten is lezajlanak. Számos mérést végeztünk az UV fény besurgázásának hatástanulmánya céljából, ezt követően próbálkoztunk $\mathrm{TiO}_{2}$ fotokatalizátor alkalmazása mellett, a katalizátort anionokkal dotálva, a gerjesztéshez szükséges energiát a látható fény tartományába eltolni. Ennek az az igazán nagyon fontos gyakorlati haszna, hogy a Nap fényét fel tudjuk használni energiaforrásnak különböző katalitikus reakciókban. Habár számos cikket közöltünk ezen kutatási eredményeinkből, ezek nem képezik a jelen disszertáció alapját. 


\section{Kísérleti körülmények}

\subsection{A mérések anyagszükséglete}

\subsubsection{A katalizátor elöállitásához használt anyagok}

- arany: hidrogén-tetrakloroaurát $\mathrm{HAuCl}_{4}, 49 \% \mathrm{Au}$, Fluka

- cérium-dioxid: $\mathrm{CeO}_{2}$ Alfa Aesar $50 \mathrm{~m}^{2} / \mathrm{g}$

- alumínium-oxid: $\mathrm{Al}_{2} \mathrm{O}_{3}$ Degussa $100 \mathrm{~m}^{2} / \mathrm{g}$

- magnézium-oxid: $\mathrm{MgO} \mathrm{DAB} 6170 \mathrm{~m}^{2} / \mathrm{g}$

- tián-dioxid: $\mathrm{TiO}_{2}$ Degussa P25 $50 \mathrm{~m}^{2} / \mathrm{g}$, Hombikat $300 \mathrm{~m}^{2} / \mathrm{g}$

- szilícium-dioxid: $\mathrm{SiO}_{2} \mathrm{CAB}-\mathrm{O}-\mathrm{SiL} 198 \mathrm{~m}^{2} / \mathrm{g}$

- norit: Alfa Aesar $859 \mathrm{~m}^{2} / \mathrm{g}$

- H-ZSM-5: Zeolit Intern. Süd-Chemie $425 \mathrm{~m}^{2} / \mathrm{g}\left(\mathrm{SiO}_{2} / \mathrm{Al}_{2} \mathrm{O}_{3}=80\right)$

\subsubsection{Katalizátorok elöállítása}

A hordozókra felvitt arany mennyisége 1 és 5\% között volt. Az arany katalizátorokat minden esetben impregnálással állítottuk elő. A szükséges mennyiségü hidrogéntetrakloroaurát törzsoldatot háromszor desztillált (milli Q) vízzel hígítottuk, majd a pH értékét 7,5-re állítottuk ammónia vizes oldatának hozzáadásával. Ezt követően a számolt mennyiségü hordozót az oldathoz adtuk, amit 353 K-en kevertettünk mágneses keverő segítségével. Majd szürtük vákuumszürővel, kloridmentesre mostuk, végül infralámpa alatt szárítottuk. Az így kapott katalizátort 573 K-en izzító kemencében 4-5 órán keresztül oxidáltuk levegőn. (ahogyan az elözményekböl is kiderült, az arany ismert két oxidja $523 \mathrm{~K}$-en aranyra és oxigénre bomlik). A termikus mérések előtt az így előállított katalizátorokat 573 K-en 30 percet oxidáltuk és $673 \mathrm{~K}$-en 60 percet redukáltuk in situ, $40 \mathrm{ml} / \mathrm{min}$-es gázáramban.

A norit hordozót a katalizátor előállítás előtt elökezeltük. 12 órán keresztül $10 \mathrm{w} / \mathrm{w} \%$ os sósav oldattal tisztítottuk, majd kloridmentesre mostuk. Ezt követően a fémszennyeződéseket, főleg a Fe-t, ICP-AES módszerrel meghatároztuk, összegük kevesebb volt, mint $0,002 \%$.

A dimetil-éter katalitikus vizsgálatai során háromféleképpen összeállított $\mathrm{CeO}_{2}$ és $\mathrm{Al}_{2} \mathrm{O}_{3}$ hordozót tartalmazó arany tartalmú katalizátort vizsgáltunk. Az első esetben 1\% 
$\mathrm{Au} / \mathrm{CeO}_{2}$-hoz mechanikusan kevertünk számolt mennyiségü alumínium-oxidot (kevert oxid), végeztünk méréseket olyan kísérleti elrendezésben, ahol az $1 \% \mathrm{Au} / \mathrm{CeO}_{2}$-ot és a tiszta $\mathrm{Al}_{2} \mathrm{O}_{3}$ ot a reaktorcsőben kvarcgyapottal választottuk el (elszeparált katalizátor), végül az arany nanorészecskék impregnálása előtt kevertük össze a két hordozót (együttesen impregnált).

\subsubsection{A kísérletekhez használt reaktánsok}

A méréseink során alkalmazott reaktánsok az 1. táblázatban láthatóak a gyártó és a tisztaságuk megjelölésével. A metanol, etanol és hangyasav folyadék halmazállapotúak szobahőmérsékleten, ezeket az alábbiakban vázolt módon szaturátor segítségével jutattuk be a rendszerbe, míg a dimetil-étert egy tömegáram szabályzón keresztül vezetve.

1. táblázat $A$ katalitikus mérések során alkalmazott reaktánsok gyártói és tisztasága

\begin{tabular}{|c|c|c|c|}
\hline Reaktáns & Gyártó & Tisztaság & $\begin{array}{c}\text { Gázáram } \\
\text { reaktánstartalma }\end{array}$ \\
\hline Metanol & Scharlau & $99,98 \%$ & $9-10 \%$ \\
\hline Etanol & BDH & $99,9 \%$ & $9-10 \%$ \\
\hline Hangyasav & BDH & $99,0 \%$ & $7 \%$ \\
\hline Dimetil-éter (DME) & Gerling Holtz & $99,9 \%$ & $10 \%$ \\
\hline
\end{tabular}




\subsection{Vizsgálati módszerek}

\subsubsection{Katalizátorok karakterizálása}

\subsubsection{TEM}

A hordozók felületére impregnált arany részecskeméretét transzmissziós elektron mikroszkópiás (TEM) módszerrel határoztuk meg. A méréseket Philips CM 20 és Morgani 268 D elektron mikroszkóppal végeztük 300 K-en. Hozzávetőlegesen $1 \mathrm{mg}$ katalizátort tettünk a TEM gridre.

\subsubsection{XPS}

A katalizátorok felületén lévő arany részecskék a reakciók alatti oxidációs állapotának változásának követése céljából röntgenfotoelektron spektroszkópiás felvételeket készítettünk. A méréseket Kratos XSAM 800 típusú készülékkel végeztük, monokromátor nélküli üzemmódban, $\mathrm{Al} \mathrm{K} \alpha(\mathrm{h} v=1486,6 \mathrm{eV})$ anódot alkalmazva röntgen-foton forrásként, a spektroszkóp $180^{\circ}$-os eltérítésű kettős félgömb analizátorral volt szerelve. Az alapnyomás $1 \times$ $10^{-9}$ mbar volt. A keletkező energiákhoz referenciának a C 1s kötési energiáját $(285,1 \mathrm{eV})$ használtuk az $\mathrm{Au} / \mathrm{SiO}_{2}$ kivételével, ahol a $\mathrm{Si} 2 \mathrm{p}(103,4 \mathrm{eV})$ energiáját használtuk.

\subsubsection{XRD}

A por röntgen diffraktogrammok a $2 \Theta=4-80^{\circ}$ tartományban Rigaku Miniflex 2 készülékkel lettek felvéve $\mathrm{Cu}-\mathrm{K} \alpha(\lambda=0,15418 \mathrm{~nm})$ gerjesztéssel.

\subsubsection{IR}

A méréseket Bio-Rad FTS 155 típusú infravörös spektrométerrel végeztük a katalizátorok felületén kialakult felületi vegyületek kimutatására, egyrészt az adszorpciót követően szívatás közben a hőmérséklet növelésével, másrészt a reaktáns + víz keverék reformálási reakció során magas hőmérsékleten illetve bevilágítás hatására. 
Az első esetben a redukált katalizátorra ráengedtük a reaktánst vagy a reaktáns-víz gáz elegyét, amit szobahőmérsékleten 30 percig tartottunk, aztán a mintát folyamatos szívatás közben fütöttük magasabb hőmérsékletekre, ahol felvettük a spektrumokat. A másik kísérletsorozatban az IR spektrumokat in situ magas hőmérsékleten regisztráltuk. A minták redukciós lépés utáni spektrumait használtuk háttérnek. 


\subsubsection{Gáz-kromatográffal vizsgált reakciók}

\subsubsection{Termikus mérések}

Az előállított arany katalizátoroknak a reaktánsok bomlási és reformálási reakcióikra gyakorolt katalitikus hatásainak meghatározására az 1. ábrán látható kísérleti elrendezést alkalmaztuk.

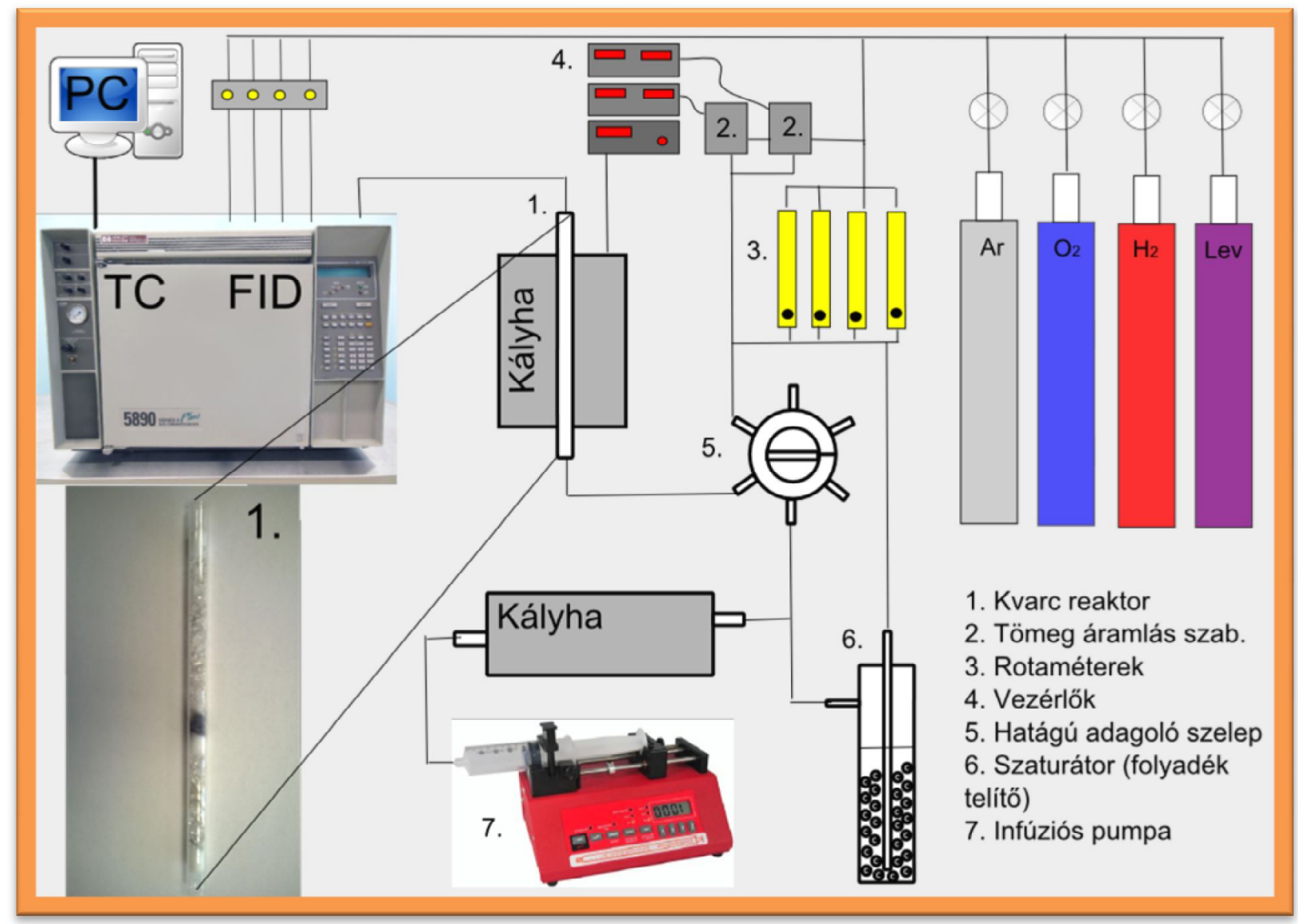

\section{1. ábra Katalitikus mérések kisérleti elrendezése}

A reakciók lejátszódását, a termékek képződését és ezek mennyiségét minden esetben HP 5890 Series II. típusú gáz-kromatográffal követtük. A különböző vegyületeket PORAPAK Q és PORAPAK S kolonnák segítségével választottuk el és hővezetőképességi (TC) valamint lángionozációs (FID) detektorokkal analizáltuk.

A reakciókat 1 atm nyomáson, álló ágyas kvarc reaktorcsőben (belső átmérője $8 \mathrm{~mm}$, hosszúsága $25 \mathrm{~cm}$ ), folyamatos áramlásban játszattuk $1 \mathrm{e}^{6,23}$. A katalizátorok 0,3 g-ját 
pasztilláztuk (prés segítségével 20 bar nyomásnak pár másodpercig kitéve), majd a reaktor közepén elhelyezve, minkét oldalról kvarcgyapottal stabilizálva akadályoztuk meg, hogy az áramlás hatására a szemcsék elmozdulhassanak. A reaktor holtterét kvarctörmelékkel csökkentettük a lehető legkisebb térfogatra. A reaktorcsövet egy szabályozható hőmérsékletü kályha vette körül, amely biztosította az állandó reakcióhőmérsékletet a kísérletek során. Egy a folyadék halmazállapotú reaktánsokat tartalmazó, szobahőmérsékletü szaturátoron argon/nitrogén vivőgáz segítségével jutattuk a reaktorba a reakcióelegyet, illetve a gázkromatográfba a termék elegyet. A vivőgáz nitrogén tartalmát minden mintavételnél meghatároztuk, ezzel bizonyosodva meg a betáplálás folyamatosságáról. Az áramlási sebesség $60 \mathrm{ml} /$ perc volt. A gázelegy reaktánstartalma 7-10\% volt. A gáz halmazállapotú dimetil-éter esetében a reaktáns-vivőgáz elegyet tömegáram szabályzók segítségével állítottuk be a kívánt értékre. A katalizátorokat a reakciók előtt minden esetben in situ előkezeltük, 30 percig $573 \mathrm{~K}$-en $40 \mathrm{ml} / \mathrm{min}$ oxigén áramban oxidáltuk, majd argonos öblítés után 60 percig 673 K-en hidrogén áramban redukáltuk, majd 15 perces ismételt argonöblítés után a legalacsonyabb reakcióhőmérsékletre hütöttük. Az argont lecserélve a rektáns gáz elegyre, a reaktort fokozatosan fútöttük 473 K-ről 773 K-re 50 K-enként, ahol az egyensúly beállta után végrehajtottuk a gázok analízisét minden hőmérsékleten. A katalizátorok stabilitásának vizsgálata céljából a rendszert több órán keresztül 773 K-en tartva 40 percenként szintén méréseket végeztünk.

\subsubsection{Reformálási reakciók}

A különböző összetételü reaktáns-víz (1:1 és 1:3) reakcióelegy reakciójának tanulmányozásakor, az elegyet egy elpárologtatóba vezettük be infúziós pumpa (MEDICOR ASSISTOR PCI 1,0 ml folyadék/ óra) segítségével, az elpárologtatóból a gázt folyamatos $\mathrm{Ar} / \mathrm{N}_{2}$-áram segítségével jutattuk a reaktorba az 1. ábrán vázolt módon egy fütött csövön keresztül, elkerülve ezzel a kondenzációt. 


\subsubsection{Hömérsékletprogramozott deszorpció TPD}

Termikus deszorpciós (TPD) méréseket is a katalitikus reaktorban hajtottuk végre. A katalizátort a már leírt módon előkezeltük, majd 333 K-en 30 percig adszorbeáltattuk a felületén a reaktánst. Ezt követően argon gázzal mostuk a rendszert. A detektálást $5 \mathrm{~K} /$ perc fütési sebesség (873 K-ig) és $20 \mathrm{ml} /$ perc argon áramlás alkalmazása mellett 6 percenként végeztük.

\subsubsection{Hömérsékletprogramozott redukció TPR}

A reakciók során képződött szén lerakódásának vizsgálata érdekében hőmérséklet programozott redukciós méréseket is végeztünk. A reakciót követően a katalizátort $20 \mathrm{ml} /$ perc tiszta hidrogén áramban felfütöttük 300 K-röl 1100 K-re 5 K/perc-es sebességgel és 5 percenként analizáltuk a képződött termékeket.

\subsubsection{Kinetikai mérések}

\subsection{A reakció hömérsékletfüggése (aktiválási energia meghatározás)}

A különböző reaktánsok reakcióinak vizsgálata során a legaktívabbnak ítélt katalizátorok esetében kiválasztottuk azt a szük hőmérséklet intervallumot ( $\Delta \mathrm{T} \sim 60 \mathrm{~K})$, ahol a konverzió érték 2 - 15\% közé esett, és ezen intervallumon belül állandó hőmérsékleteken méréseket végeztünk detektálva a képződő termékeket. Ábrázolva a képződési sebességek negatív logaritmusát az 1/T függvényében egyenest kaptunk. Ezen egyenes meredekségéből számoltuk ki a reakcióra vonatkozó aktiválási energiákat.

\subsection{A reakció nyomásfüggése (rendüség meghatározás)}

A reakciók rendüségének mérésénél a betáplált reaktáns parciális nyomását változtattuk, míg az teljes áramlási sebességet állandó értéken tartottunk. Így alacsony 
konverziónak megfelelő hőmérsékleten egy adott katalizátoron detektáltuk a képződött termékeket. A reaktáns parciális nyomásának logaritmusának függvényében ábrázolva a képződési sebességek logaritmusát egyenest kaptunk. Az adott termékekhez tartozó egyenes meredeksége szolgált a rendüség meghatározására. 


\subsection{Számítási módok}

a., Az arany katalizátorok diszperzitásának meghatározása

A diszperzitás megadja, hogy a katalizátorok fém tartalmának hány százaléka érhető el a reakció számára.

Köztudott, hogy az arany felületén csak nagyon kis mértékben adszorbeálódik a hidrogén, így az általunk használt katalizátorok esetében a diszperzitás meghatározására nem alkalmazható a jól ismert BET-módszer. A katalizátorok diszperzitását az irodalomban is elfogadott módszerrel számítottuk ${ }^{87,88}$ :

$$
\mathbf{d}=\frac{6 * \mathbf{A}}{\rho * \delta * \mathbf{L} * \mathrm{D}}
$$

d: a fém átlagos szemcsemérete

A: a fém atom tömege

р: a fém sürüsége

$\boldsymbol{\delta}$ : egy fématom helyigénye

L: Avogadró szám

D: diszperzitás

b., Képzödési sebesség

A képződött termékek illetve az elbomlott reaktáns mennyiségét minden esetben a katalizátor tömegegységére vonatkoztattuk és nmol/gs egységben adtuk meg.

$$
\mathbf{V}_{\text {képzödés }}=\frac{\mathbf{n}_{\mathbf{i}} * \mathbf{v}}{\mathrm{V} * 60 \mathrm{~s} * \mathrm{~m}}
$$

$\mathbf{n}_{\mathrm{i}}$ : képződött termék mennyisége

v: áramlási sebesség

V: minta (loop) térfogata

m: katalizátor tömege 


\section{c., Konverzió}

A reaktáns konverzióját háromféleképpen számítottuk ki. Elsőként meghatároztuk, hogy a betáplált mennyiség hány százaléka bomlott illve reagált el. Majd a képződött termékek $\mathrm{H}$ és $\mathrm{C}$ tartalmát alapul véve hasonlóképpen határoztuk meg. Az eredményeket csak akkor fogadtuk el, ha a H- és a C-mérleg is közel megegyezett a reaktáns konverziójával, így biztosak lehettünk abban, hogy az összes elbomlott reaktáns termékké alakult illetve a reakcióban képződött összes terméket kvantitatívan és kvalitatívan is meg tudtuk határozni.

$$
K=\frac{\mathbf{n}_{0}-\mathbf{n}_{\mathbf{i}}}{\mathbf{n}_{\mathbf{0}}} * 100 \%
$$

$\mathbf{n}_{0}$ : betáplált reaktáns mennyisége

$\mathbf{n}_{\mathbf{i}}$ : el nem reagált reaktáns mennyisége

\section{d., Termék százalékos összetétele}

A termékek százalékos összetételét százalékszámítással határoztuk meg, mely megadja, hogy az adott termék mennyisége hány százaléka az összes képződött terméknek.

$$
\mathbf{x}_{\mathbf{i}}=\frac{\mathbf{n}_{\mathbf{i}}}{\mathbf{n}_{\ddot{0}}} \quad * 100 \%
$$

$\mathbf{n}_{\mathbf{i}}$ : képződött termék mennyisége

$\mathbf{n}_{\mathbf{0}}$ : összes képződött termék mennyisége

\section{e., Hidrogén szelektivitás}

Megadja, hogy a képződött hidrogén hány százaléka az összes termék hidrogéntartalmának.

$$
S_{\mathrm{H} 2}=\frac{\mathbf{n}_{\mathrm{H} 2}}{\mathbf{n}_{\ddot{0}(\mathrm{H} 2)}} * 100 \%
$$

$\mathbf{n}_{\mathrm{H}_{2}}$ : képződött hidrogén mennyisége

$\mathbf{n}_{\mathbf{o}(\mathbf{H})}$ : képződött termékek összes hidrogén tartalma 
A hangyasav esetében ez a számítási mód nem alkalmazható, mivel jelentős mennyiségü víz képződik a reakcióban, melynek pontos meghatározását a kísérleti körülményeink nem tették lehetővé. Így az alábbi képlettel jutottunk közelítő eredményekhez:

$$
\mathrm{S}_{\mathrm{H} 2}=\frac{\mathbf{n}_{\mathrm{CO} 2}}{\mathbf{n}_{\mathrm{CO}}+\mathbf{n}_{\mathrm{CO} 2}} * 100 \%
$$

$\mathbf{n}_{\mathrm{CO} 2}$ : képződött szén-dioxid mennyisége

$\mathbf{n}_{\mathbf{C O}}$ : képződött szén-monoxid mennyisége

\section{f., Yield értékek számítása}

Egy adott reakció yield értéke megadja a kitermelés mértéket, amely együttesen magába foglalja a szelektivitást és a konverziót is.

$$
\mathbf{Y}_{\mathrm{H}_{2}}=\frac{\mathbf{S}_{\mathrm{H}^{2}} * \mathbf{K}}{100 \%}
$$

\section{g., Effektív yield}

Megadja, hogy az elreagált reaktáns hidrogén tartalmának hány százaléka alakult át tiszta hidrogénné.

$$
Y_{\text {eff }}=\frac{n_{H_{2}}}{n\left(H_{2}\right)_{0}-n\left(H_{2}\right)_{i}} * 100 \%
$$

$\mathbf{n}_{\mathbf{H} 2}$ : képződött hidrogén mennyisége

$\mathbf{n}\left(\mathbf{H}_{2}\right)_{0}$ : betáplált reaktán hidrogén tartalma

$\mathbf{n}\left(\mathbf{H}_{2}\right)_{\mathbf{i}}$ : el nem reagált reaktáns hidrogén tartalma

\section{h., TOF turneover frequency számítások}

Felületi fématomra vonatkozó reakciósebesség, vagyis egy fématomon időegység alatt végbemenő átalakulások száma egy adott termék képződésére vagy a reaktáns átalakulására vonatkozóan. 


\section{Mérési eredmények bemutatása és értelmezése}

\section{Mérési eredmények bemutatása és értelmezése}

\subsection{Katalizátorok jellemzése}

A nanorészecskék legfontosabb tulajdonsága, ami miatt egyre több kutató fordul e terület felé, hogy a méret csökkenésével nagymértékben megnő a szilárd részecskék fajlagos felülete. Ennek következtében anyagi tulajdonságaik drasztikus változáson mennek keresztül a megszokott, jól ismert makroszkópikus formájukhoz képest. Az arany nanorészecskék

lilává változnak és színük mélyül részecskeméretük csökkenésének függvényében. Ez jól látszik az általunk előállított, különböző részecskeméretű aranytartalmú katalizátorok esetében is (2. ábra).

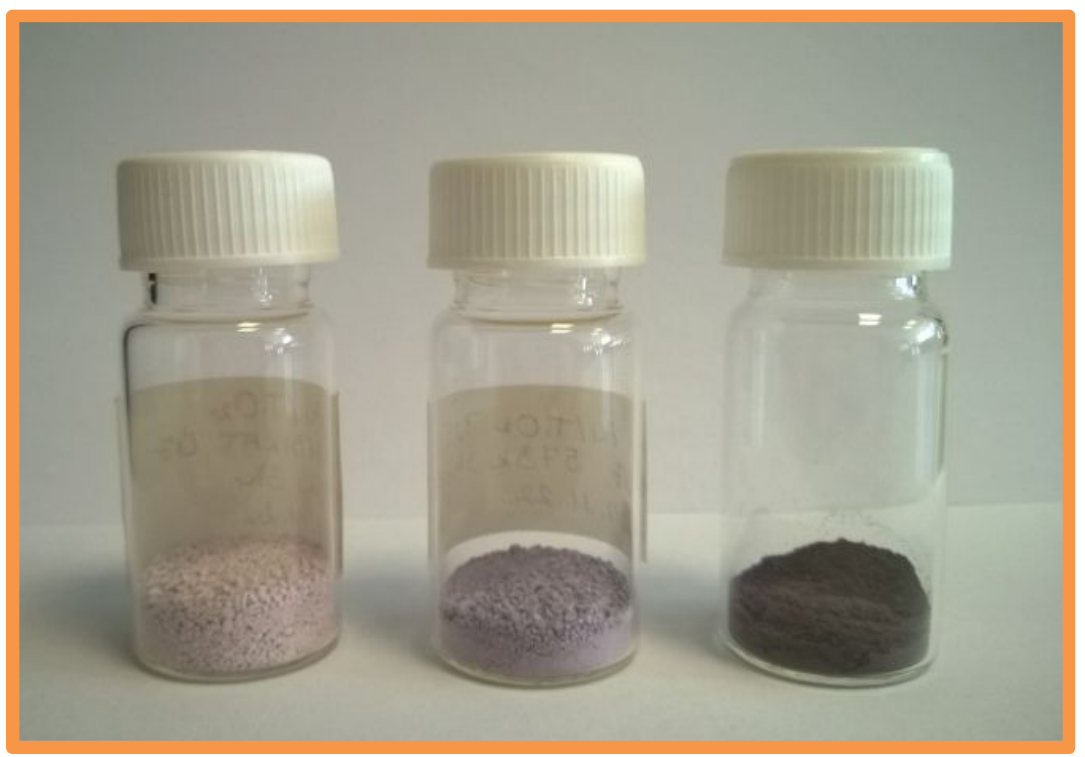

2. ábra $\mathrm{Az} \mathrm{Au} / \mathrm{CeO}_{2}$ katalizátorok színének függése a részecskemérettöl. Az arany átlagos részecskemérete balról jobbra 144, 68 és $2 \mathrm{~nm}$.

\subsubsection{TEM felvételek}

Az előállított különböző hordozós arany nanorészecskéket tartalmazó katalizátorok transzmissziós elektronmikroszkópos felvételei a 3. ábrán láthatóak. 


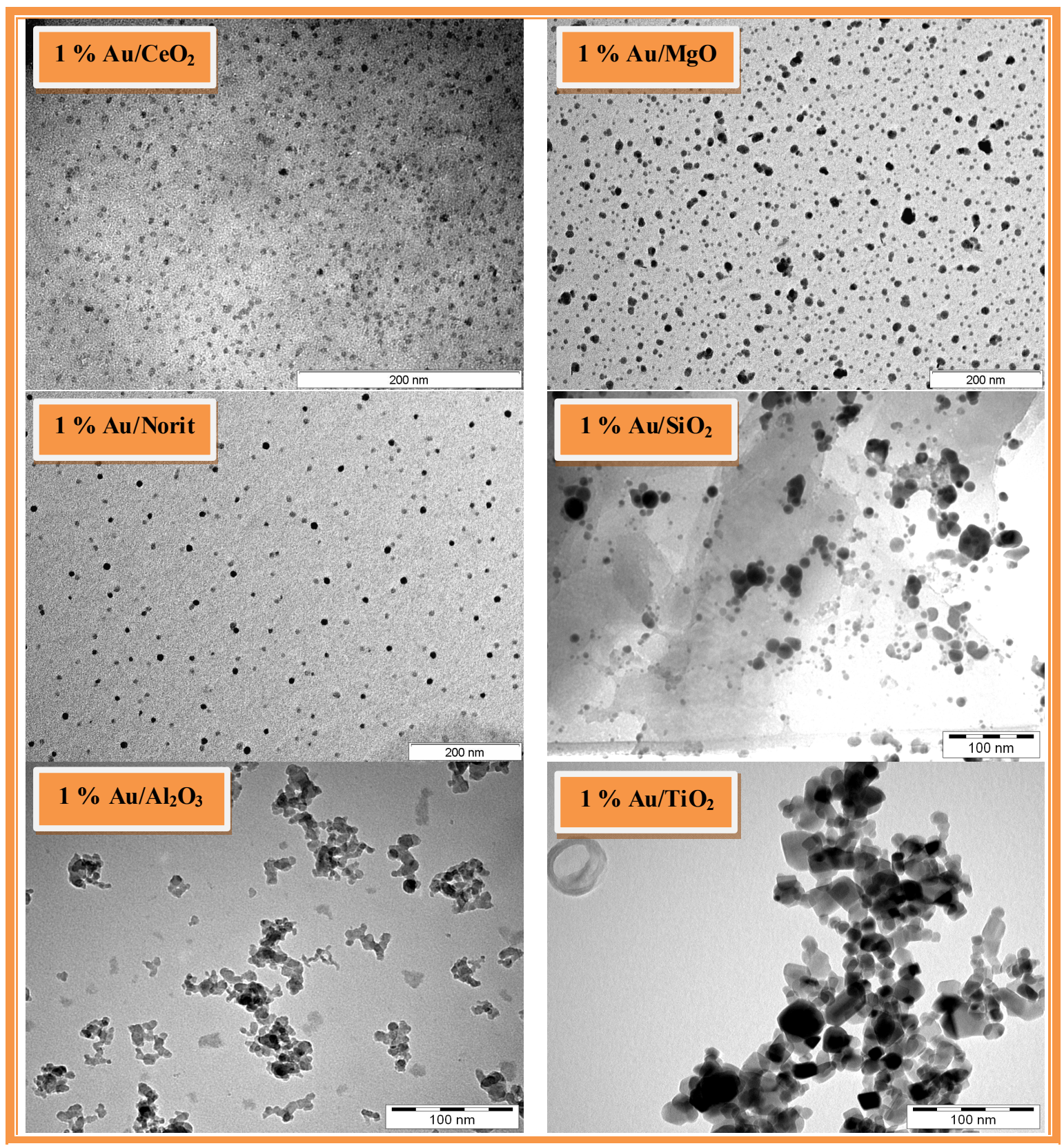

3. ábra A kísérletek során vizsgált katalizátorok TEMfelvételei.

A vizsgált mintákban a hordozók felületén jól diszpergált formában $\mathrm{Au}$ nanorészecskéket figyelhetünk meg. Az Au nanorészecskék alakja a legtöbb esetben megközelítőleg gömbszimmetrikus, méretük pedig szük tartományon belül változik $(1-25$ $\mathrm{nm})$. Néhány esetre vonatkozóan a TEM felvételek alapján meghatározott arany nanorészecskék méreteloszlását a 4. ábra mutattuk be. 


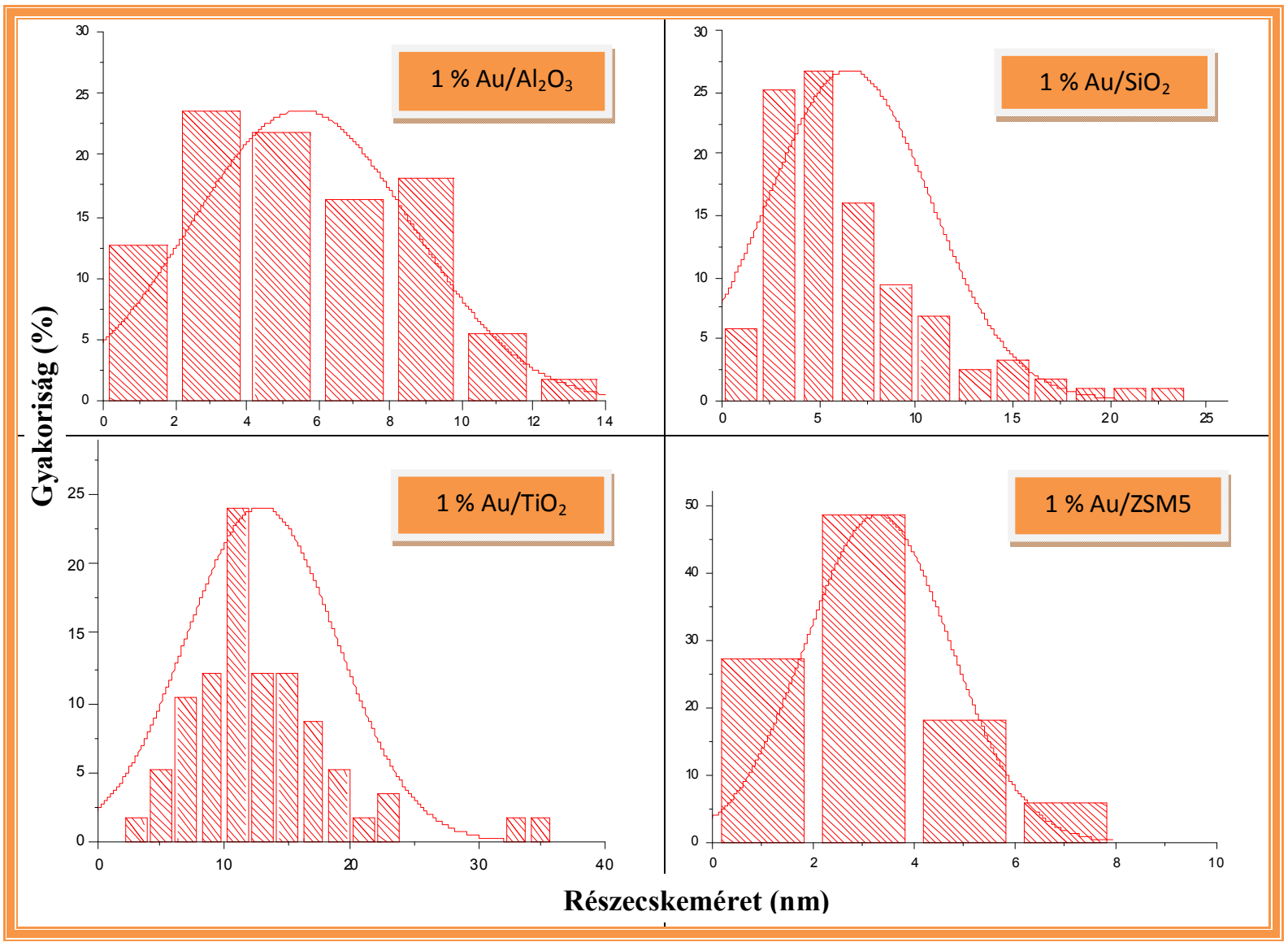

4. ábra $1 \%$ Au tartalmú $\mathrm{Al}_{2} \mathrm{O}_{3}, \mathrm{SiO}_{2}, \mathrm{TiO}_{2}$ és ZSM5 hordozós katalizátorok arany részecskék méreteloszlása

2. táblázat Az arany tartalmú különbözö hordozós katalizátorok arany tartalmának átlagos részecske mérete és diszperzitása

\begin{tabular}{lcc}
\hline Katalizátor & $\begin{array}{c}\text { Átlagos } \\
\text { részecskeméret } \\
(\mathbf{n m})\end{array}$ & Diszperzitás \\
\hline $\mathbf{1 \%} \mathbf{A u} / \mathbf{C e O}_{2}$ & 1,9 & 0,74 \\
$\mathbf{1 \%} \mathbf{A u} / \mathbf{A l}_{\mathbf{2}} \mathbf{O}_{3}$ & 5,5 & 0,26 \\
$\mathbf{1 \%} \mathbf{A u} / \mathbf{M g O}_{\mathbf{1 0}}$ & 2,1 & 0,67 \\
$\mathbf{1 \%} \mathbf{A u} / \mathbf{T i O}_{2}$ & 12,4 & 0,11 \\
$\mathbf{1 \%} \mathbf{A u} / \mathbf{S i O}_{\mathbf{2}}$ & 6,5 & 0,21 \\
$\mathbf{1 \%} \mathbf{A u} / \mathbf{n o r i t}$ & 5,7 & 0,25 \\
$\mathbf{1 \%} \mathbf{A u} / \mathbf{H}-\mathbf{Z S M}-5$ & 3,3 & 0,33 \\
\hline
\end{tabular}




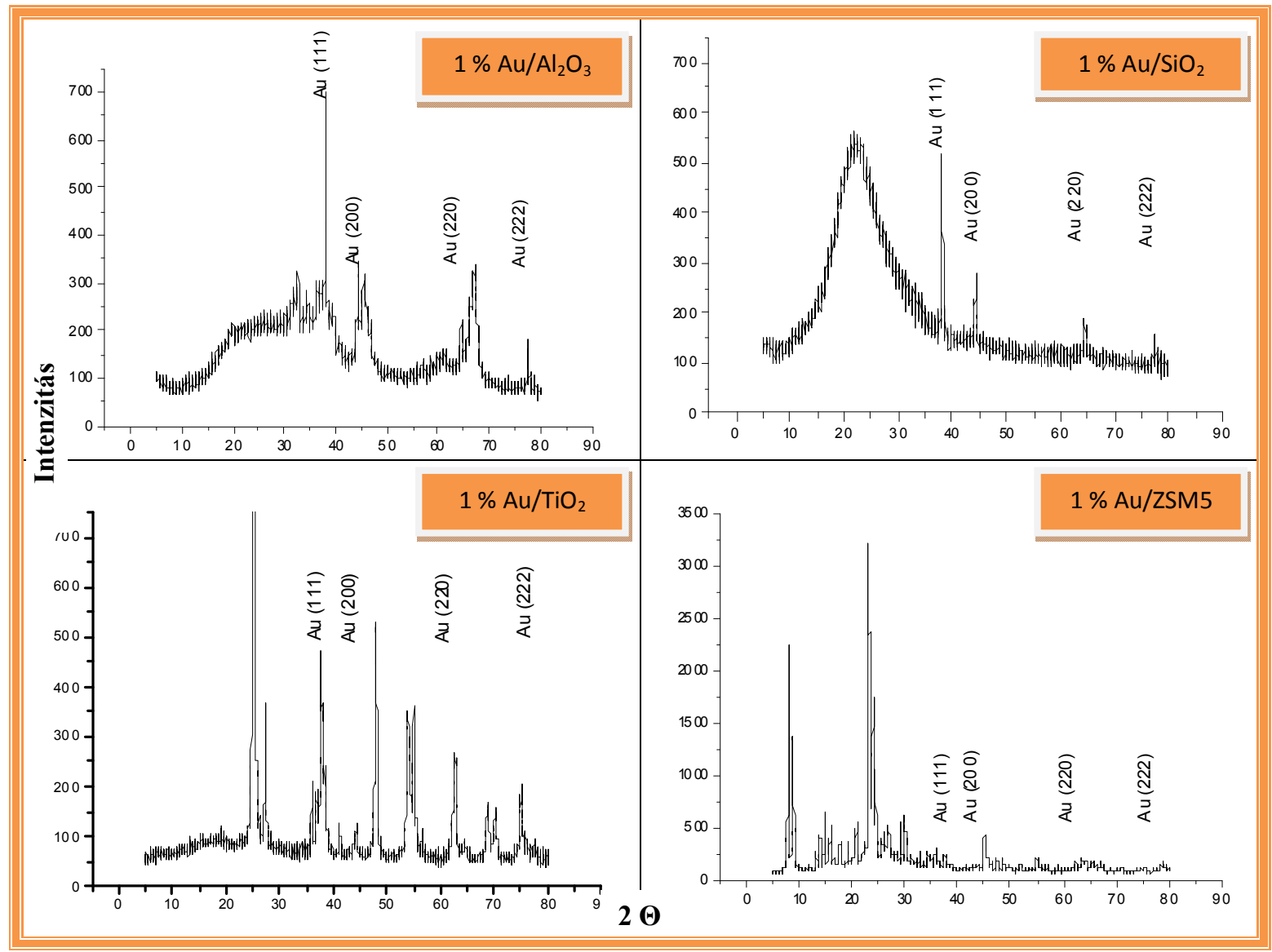

5. ábra $1 \%$ Au tartalmú $\mathrm{Al}_{2} \mathrm{O}_{3}, \mathrm{SiO}_{2}, \mathrm{TiO}_{2}$ és ZSM5 hordozós katalizátorok arany részecskék XRD felvételei

$\mathrm{Az} 1 \% \mathrm{Au} / \mathrm{TiO}_{2}$ esetében kapott röntgen diffraktogrammon jól azonosíthatók az anatázra $\left[2 \theta=25,3^{\circ}(101), 37,8^{\circ}(004), 48,0^{\circ}(200), 53,8^{\circ}(105), 54,9^{\circ}(211)\right.$ és a $\left.62,5^{\circ}(204)\right]$ jellemző reflexiók. A rutilra $\left[2 \theta=27,3^{\circ}(100), 36,1^{\circ}(101) 41,2^{\circ}\right.$ (111) és 56,6 $6^{\circ}$ (211)] jellemző reflexiók alapján megállapítható, hogy a $\mathrm{TiO}_{2}$ hordozós katalizátor jellemzően

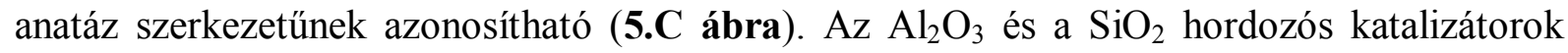
esetében egy jellemző reflexiót kapunk a hordozóra és emelett az aranyra jellemző reflexiókat kapjuk. A ZSM-5 esetében a 7-9 és a 23-25 $2 \theta$ értékeknél kapott reflexiók a zeolit kristályszerkezetéhez azonosíthatóak. Az aranyra kapott értékek intenzitása kisebb, mint a többi hordozó esetében ebből arra következtehetünk, hogy a részecskék egy része a zeolit belső pórusa vándorolt. 


\subsubsection{Diszperzitások meghatározása}

A kísérleteink során alkalmazott katalizátorok arany tartalmának átlagos részecskeméreteit és a hozzájuk tartozó diszperzitás értékeket a 2. táblázat tartalmazza. A diszperzitások közelítő értékeinek meghatározását az (1. egyenlet segítségével végeztük, ahol a fém atom tömege $\mathrm{A}=196,967 \mathrm{~g} / \mathrm{mol}$, a fém sürüsége $\rho=19,3 * 106 \mathrm{~g} / \mathrm{m}^{3}$ és egy fém atom helyigénye $\delta=7,2 * 10^{-20} \mathrm{~m}^{2}$ értékekkel számoltunk.

\subsubsection{Au minták XPS jellemzése}

Néhány hordozós Au katalizátor XPS spektrumát mutatja a 6. ábra. $\mathrm{Az} A u$ f tartományában az arany három állapotának kötési energiáit kaptuk: 84,0 eV az Au ${ }^{0}$-nál, 84,6 eV-ot $\mathrm{Au}^{1+}$ és az $\mathrm{Au}^{3+}$-nál 85,9 $\mathrm{eV}^{52,89,90}$. Az oxidált arany minták XPS spektrumának mennyiségi elemzése kimutatta, hogy az $\mathrm{Au}^{3+}$ mellett az arany egy része $\mathrm{A}^{1+}$ állapotban van.

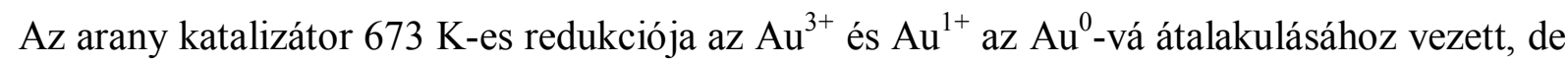
$\mathrm{az} \mathrm{Au}^{1+}$ nem tünt el teljesen. Valószínű oka, hogy az arany nanorészecskékben az $\mathrm{Au}^{1+}$-ot stabilizálja a hordozó.

$\mathrm{Az}$ oxidált $\mathrm{Au} / \mathrm{CeO}_{2}$ katalizátor $\mathrm{CeO}_{2}$ XPS tartományának vizsgálata alapján a meghatározó csúcsok 882,6 és 898,4 eV-nál jelentkező domináns csúcsok a Ce ${ }^{4+}$ állapotának tulajdonítható. A 885,1 és 900,4 eV-nál kapott vállak azonban feltárták a $\mathrm{Ce}^{3+}$ jelenlétét a kiindulási anyagnál ${ }^{11-93}$. Az a tény, hogy a $\mathrm{Ce}^{3+}$ kötési energiái már akkor megjelentek, amikor az arany a hordozóra került azt feltételezi, hogy az arany és $\mathrm{CeO}_{2}$ közötti erös kölcsönhatás a $\mathrm{Ce}^{4+}$ részleges redukcióját okozta. Hasonló jelenséget tapasztaltak néhány $\mathrm{Pt}$ fém esetében is $\mathrm{CeO}_{2}$ hordozón ${ }^{52,93}$. Ezek a tulajdonságok sokkal nyilvánvalóbbá váltak az $\mathrm{Au} / \mathrm{CeO}_{2}$ katalizátor magas hőmérsékletű redukciója után. A $2 \% \mathrm{Au} / \mathrm{SiO}_{2}$ oxidációja után az $\mathrm{Au} 4 \mathrm{f}$ tartományánál kapott csúcsok az $\mathrm{Au}^{3+}, \mathrm{Au}^{+}$és $\mathrm{Au}^{0}$ jelenlétét mutatják. A 673 K-es redukció növelte $\mathrm{az} \mathrm{Au}^{0}$ csúcs intenzitását, de hasonlóan az $1 \% \mathrm{Au} / \mathrm{CeO}_{2}$-hoz nem tüntette el

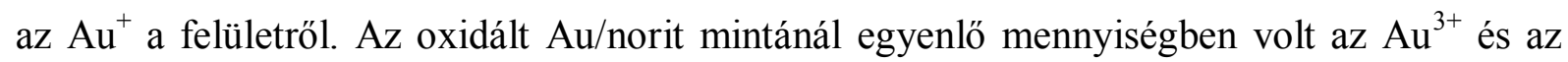

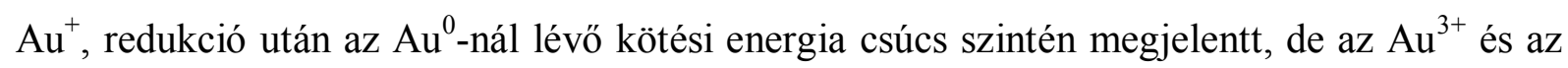
$\mathrm{Au}^{+}$jelek továbbra is jelen voltak. 


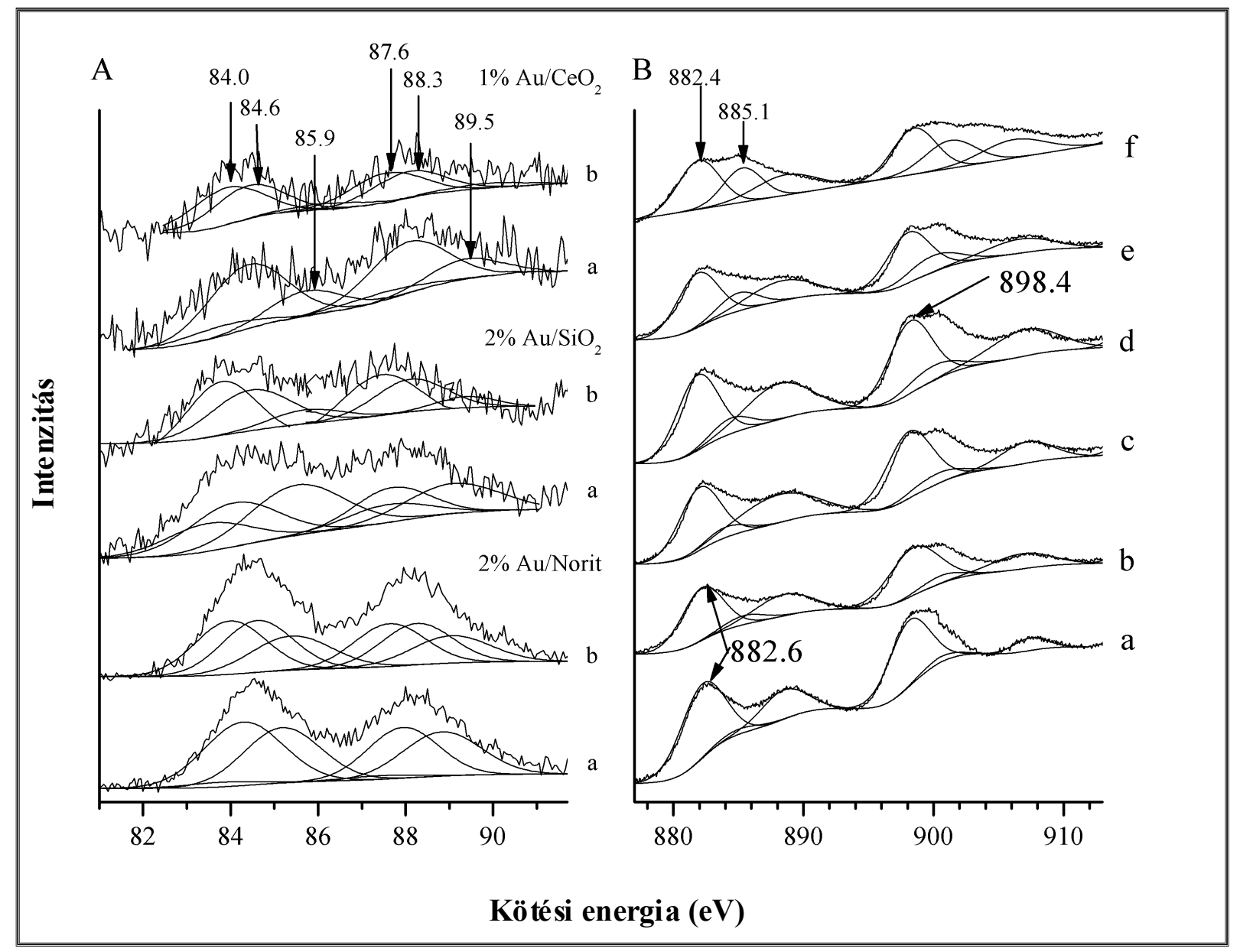

6. ábra (A) az Au 4 f tartományának XPS spektruma $1 \% \mathrm{Au} / \mathrm{CeO}_{2}, 2 \% \mathrm{Au} / \mathrm{SiO}_{2}$ és $2 \% \mathrm{Au} /$ norit hordozók esetében: (a) oxidálva $573 \mathrm{~K}$-en, (b) redukálva $673 \mathrm{~K}$-en 1 órát. (B) $1 \% \mathrm{Au} / \mathrm{CeO}_{2}$ cérium tartományának XPS spektruma: (a) oxidálva $573 \mathrm{~K}$-en, majd különbözö hömérsékleten redukálva, (b) $373 \mathrm{~K}$, (c) $473 \mathrm{~K}$, (d) $573 \mathrm{~K}$, (e) $673 \mathrm{~K}$ és (f) $773 \mathrm{~K}$-en. 


\subsection{Reaktánsok katalitikus bontása és reformálása}

\subsubsection{Metanol vizsgálata}

\subsubsection{Infravörös spektroszkópiás mérések}

A 7.A ábrán mutattuk be a metanol adszorpciójának IR spektrumát a tiszta $\mathrm{CeO}_{2}$-on $\left(T_{\mathrm{R}}=673 \mathrm{~K}\right) 300 \mathrm{~K}$-en és különböző hömérsékletekre felfütve a mintát folyamatos szívatás mellett. 300 K-en 2,940;2,915;2,889;2,840 és 2,809 $\mathrm{cm}^{-1}$-nél figyeltünk meg elnyelési sávokat a C-H rezgési tartományban.

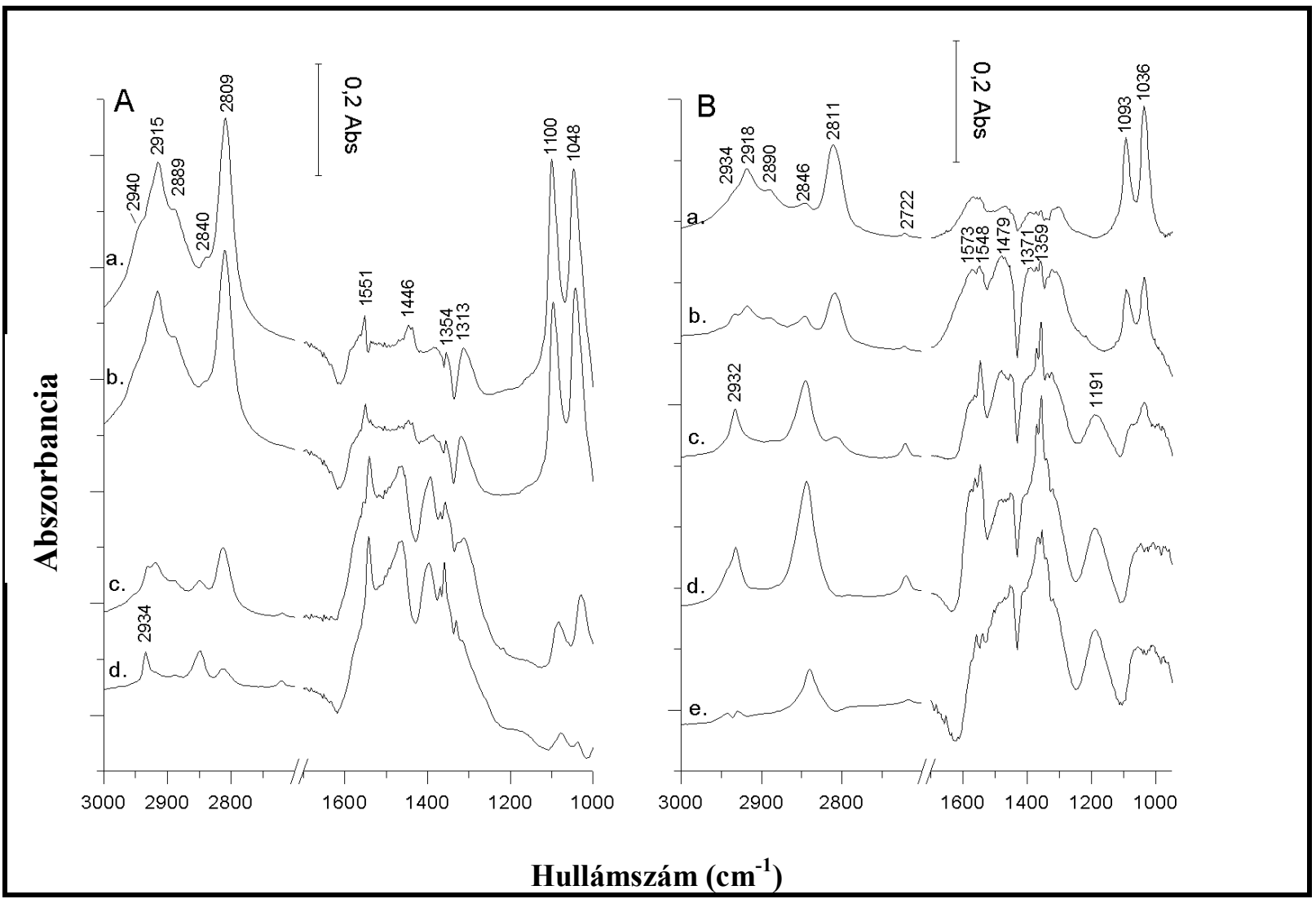

7. ábra FTIR spektrum a metanol adszorpcióját követöen $\mathrm{CeO}_{2}(\mathrm{~A})$ és $1 \% \mathrm{Au} / \mathrm{CeO}_{2}$ (B) $300 \mathrm{~K}$-en és az azt követö szivvatás után különbözö hömérsékleteken.

$a, 300 \mathrm{~K} ; b, 373 \mathrm{~K} ; c, 473 \mathrm{~K} ; d, 573 \mathrm{~K} ; \mathrm{e}, 673 \mathrm{~K}$

Az alacsony frekvenciájú tartományban két domináló csúcsot láthatunk 1,100 és 1,048 $\mathrm{cm}^{-1}$-nél. Az adszorbeált réteg hőkezelése során azt tapasztaltuk, hogy csökkennek az intenzív csúcsok. Ugyanakkor a kisebb csúcsok, illetve vállak 2,934-2,944; 2,840 és 1,551 cm ${ }^{-1}$-nél hangsúlyosabbá váltak. Különböző spektrális jellemzőket találtunk a metanol adszorpciójánál 
az 1\% Au/ $\mathrm{CeO}_{2}$-on is (7.B ábra). 300-373 $\mathrm{K}$ között különböző intenzitású abszorpciós sávok jelentek meg 2,$934 ; 2,918 ; 2,890 ; 2,846 ; 2,811 ; 1,573 ; 1,548 ; 1,479 ; 1,371 ; 1,093$ és 1,036 $\mathrm{cm}^{-1}$-nél. Fontos megemlíteni, hogy a metanol adszorpciója során mindkét mintán megjelenik a jól ismert két sáv az $\mathrm{OH}$ frekvencia tartományban 3,667 és 3,687 $\mathrm{cm}^{-1}$-nél (az ábrán nincs feltüntetve), ezek jelzik, hogy a felületi $\mathrm{OH}$ csoportok a metanollal reagálva elfogynak és metoxi csoportokat eredményeznek az alábbi egyenlet szerint:

$\mathrm{CH}_{3} \mathrm{OH}_{(\mathrm{a})}+\mathrm{OH}_{(\mathrm{a})}=\mathrm{CH}_{3} \mathrm{O}_{(\mathrm{a})}+\mathrm{H}_{2} \mathrm{O}_{(\mathrm{g})}$

A mintát $473 \mathrm{~K}$-re fütve jelentős változás megy végbe az $\mathrm{Au} / \mathrm{CeO}_{2} \mathrm{IR}$ spektrumában: a 2,918; 2,890 és $2,811 \mathrm{~cm}^{-1}$-nél látható sávok intenzitása jelentősen lecsökken. Ellentétben a következő hullámszámoknál intenzívebb sávok fejlődnek: 2,932; 2,844; 2,722; 1,565-1,545; 1,$370 ; 1,359$ és $1,191 \mathrm{~cm}^{-1}$-nél. $\mathrm{A} \mathrm{CH}_{3} \mathrm{OH}: \mathrm{H}_{2} \mathrm{O}(1: 1)$ együttes adszorpciója csak egy enyhe különbséget eredményezett az IR spektrumban a víz nélküli spektrumhoz képest. Annak érdekében, hogy az elnyelési sávok azonosítását alátámasszuk, meghatároztuk a $\mathrm{HCOOH}$ adszorpciójának FTIR spektrumát $\mathrm{CeO}_{2}$-on és $\mathrm{Au} / \mathrm{CeO}_{2}$-on. Intenzív vonalakat figyeltünk meg 2,850; 1,540-1,558; 1,381-1,355 és $1,307 \mathrm{~cm}^{-1}$-nél. A 3. táblázatban a metanol adszorpciójának a jellegzetes rezgéseit gyüjtöttük össze, és a lehetséges bomlási termékeket is bele vettük az eredményekbe a korábbi tanulmányok figyelembe vételével ${ }^{36,37,94-99}$

3. táblázat $A$ felületi formák és a hozzájuk rendelt hullámszámok a metanol adszorpcióját követöen megfigyelt FTIR spektrumok alapján különbözö szilárd felületeken

\begin{tabular}{ll}
\hline Különböző felületeken adszorbeált csoportok & Hullámszám $\left(\mathbf{c m}^{-1}\right)$ \\
\hline Metoxi $\mathrm{CeO}_{2}$-on; $\mathrm{T}_{\mathrm{R}}=523 \mathrm{~K}^{95}$ & 2,$921 ; 2,883 ; 2,802 ; 1,103 ; 1,061$ \\
Metoxi $\mathrm{CeO}_{2}$-on; $\mathrm{T}_{\mathrm{R}}=673 \mathrm{~K}^{95}$ & 2,$922 ; 2,843 ; 2,782 ; 1,075 ; 1,061$ \\
Formiát $\mathrm{Ti}^{4+37}$ & 2,$864 ; 1,560-1,578 ; 1,378-1,381 ; 1,349-1,369$ \\
Formiát $\mathrm{Au} / \mathrm{TiO}_{2}$-on ${ }^{37}$ & 2,$948 ; 1,632 ; 1,308$ \\
Formaldehid $\mathrm{Au} / \mathrm{TiO}_{2}$-on ${ }^{37}$ & 2,$844 ; 2,731 ; 1,596$ \\
Formiát $\mathrm{CeO}_{2}$-on [jelen tanulmány] & 2,$850 ; 1,558-1,540 ; 1,381-1,357 ; 1,307$ \\
\hline
\end{tabular}




\subsubsection{Hömérséklet programozott deszorpciós mérések (TPD)}

A különféle termékekre vonatkozó TPD spektrumok a metanol 333 K-en történő adszorpcióját követően $1 \% \mathrm{Au} / \mathrm{CeO}_{2}$-on a 8. ábrán láthatóak. A metanol deszorpciója $333 \mathrm{~K}$ körül gyengén indul be és $400 \mathrm{~K}$ körül éri el a maximumot. Ugyanakkor különböző vegyületek deszorpcióját is megfigyeltük: $\mathrm{H}_{2}\left(\mathrm{~T}_{\mathrm{P}}=600 \mathrm{~K}\right), \mathrm{CO}\left(\mathrm{T}_{\mathrm{P}}=600 \mathrm{~K}\right)$ és egy nagyon kis mennyiségü $\mathrm{CH}_{4}\left(\mathrm{~T}_{\mathrm{P}}=600 \mathrm{~K}\right)$. Tiszta $\mathrm{CeO}_{2}$-on a metanol deszorpcióját $\mathrm{T}_{\mathrm{P}}=375 \mathrm{~K}$ körül tapasztaltuk, mellette egy kevés $\mathrm{H}_{2}$ és $\mathrm{CO}$ mennyiséget figyeltünk meg $\left(\mathrm{T}_{\mathrm{P}}=600 \mathrm{~K}\right)(\mathbf{8}$.B ábra). $\mathrm{Az} \mathrm{Au} / \mathrm{SiO}_{2}$ TPD spektrumán a metanol csak egy kis csúcsot adott $\mathrm{T}_{\mathrm{P}} \approx 473 \mathrm{~K}$-el, és a $\mathrm{H}_{2}$ és $\mathrm{CO}$ parányi deszorpciós mennyisége magasabb hőmérsékleten $\mathrm{T}_{\mathrm{P}}=800 \mathrm{~K}$-nél volt tapasztalható.

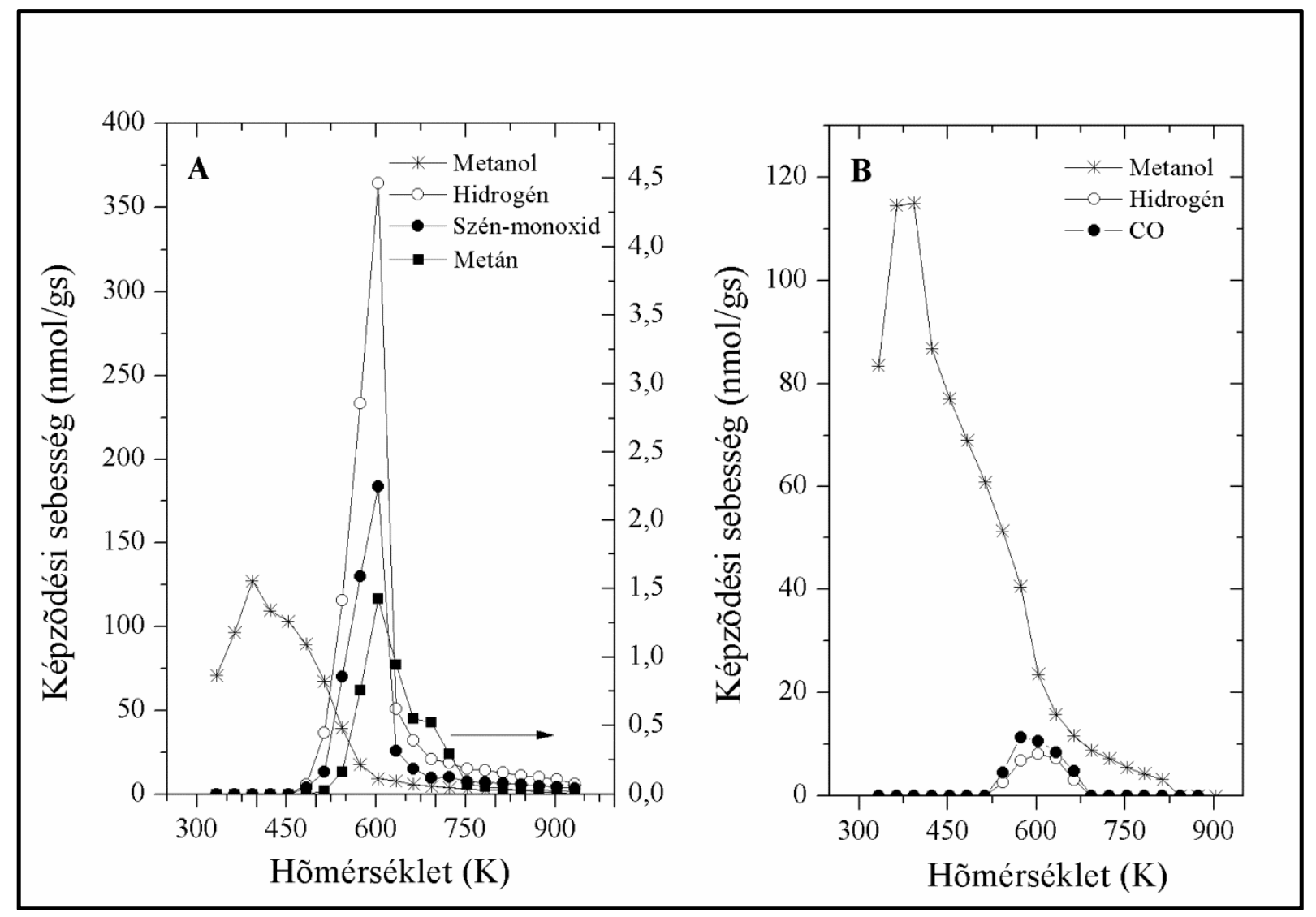

8. ábra A metanol 333 K-en történő adszorpcióját követö TPD spektrum $1 \% \mathrm{Au} / \mathrm{CeO}_{2}$-on (A) és tiszta $\mathrm{CeO}_{2}$-on (B). 


\subsubsection{Metanol bomlása}

A 9.A ábra mutatja be a metanol konverzióját különböző hordozós arany katalizátorokon. Jól látszik, hogy az arany katalizátor katalitikus teljesítményét drámaian befolyásolja a hordozó természete. A legaktívabb katalizátorokon, az $\mathrm{Au} / \mathrm{CeO}_{2}$-on és az $\mathrm{Au} / \mathrm{Al}_{2} \mathrm{O}_{3}$-on a bomlás megkezdődik $500 \mathrm{~K}$ körül és a teljes konverziót $773 \mathrm{~K}$-nél közelítették meg. Érdekes módon az $\mathrm{Au} / \mathrm{TiO}_{2}$-on és az Au/noriton a metanol konverziója csak $723 \mathrm{~K}$-ig nő, azután leesik alacsonyabb értékekre. A kevésbé aktív $\mathrm{Au} / \mathrm{SiO}_{2}$-on: a bomlás mértéke 773 K-en csak 5-6\%. A mért konverziók alapján 573-673 K tartományban a hordozók hatékonysága csökkenő sorrendben: $\mathrm{CeO}_{2}>\mathrm{Al}_{2} \mathrm{O}_{3}>\mathrm{TiO}_{2}>\mathrm{MgO}>$ norit $>\mathrm{SiO}_{2}$.
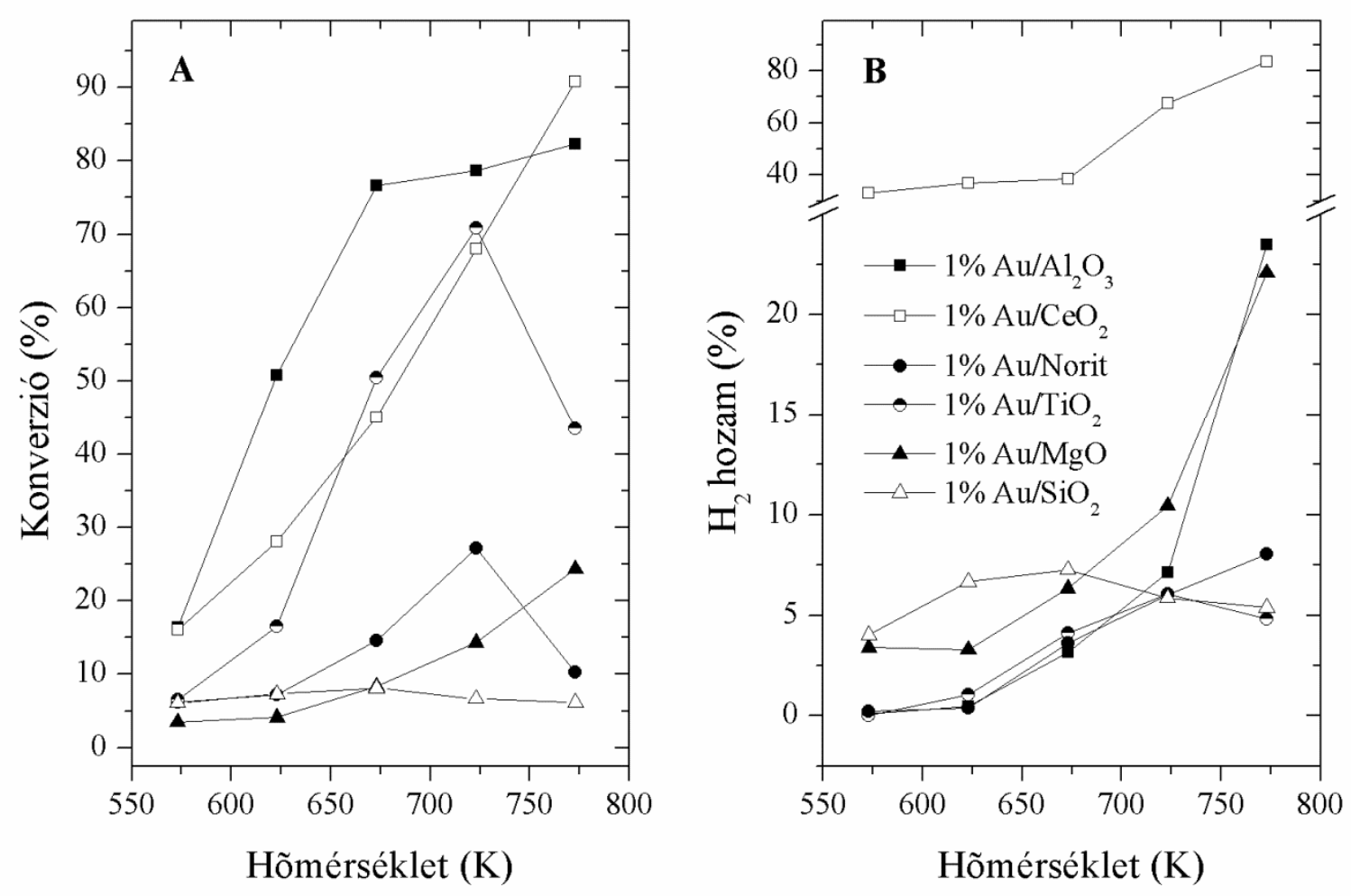

9. ábra Metanol konverziója (A) és a hidrogénképződés hozama (B) különbözö hordozós arany katalizátorokon a hömérséklet függvényében

Jelentős különbségek figyelhetőek meg a katalizátorok között a termékeloszlásra vonatkozólag. A 10.A ábrán látható, hogy az $1 \% \mathrm{Au} / \mathrm{CeO}_{2}$-on a főbb termékek a $\mathrm{H}_{2}(68 \%)$ és a CO (27\%). $523 \mathrm{~K}$-töl DME is képzödik 5\%-ban $573 \mathrm{~K}$-ig, viszont majdnem teljesen 
eltünik a termékekből. Metánt és $\mathrm{CO}_{2}$-t csak 3-4\%-ban találtunk. A hidrogén-tartalmú termékek között a $\mathrm{H}_{2}$ szelektivitása nagyon magas volt, közel $90 \%$. A bomlást $773 \mathrm{~K}$-en időben követve csak a konverzióban találtunk lassú csökkenést a mért időintervallumban, ami 8 óra volt (11.A ábra). A termék összetétel is állandó maradt ezt jelezte, hogy a $\mathrm{H}_{2} / \mathrm{CO}$ aránya mindvégig változatlan maradt, 2,5 .

Hasonló képet kaptunk az 1\% $\mathrm{Au} / \mathrm{MgO}$ esetében, ahol fö termékként ismét $\mathrm{H}_{2}$ és $\mathrm{CO}$ volt detektálható (10.B ábra). Más hidrogén tartalmú vegyületek képződése úgy, mint a metán, formaldehid és a dimetil-éter 3\% alatt maradt. A hidrogén szelektivitása 80-90\% közötti értéket adott, viszont a konverzió csak alacsony értéket ért el, még $773 \mathrm{~K}$-en is csak $25 \%$ volt (9.A ábra). Ennek a katalizátornak az egyik fontos tulajdonsága a magas stabilitása; nem csökkent a konverzió értéke és a termékösszetétel sem 773 K-en 8 óra elteltével. A metanol bomlása 1\% Au/norit-on főleg DME-t eredményezett egészen $673 \mathrm{~K}$-ig (10.C ábra).

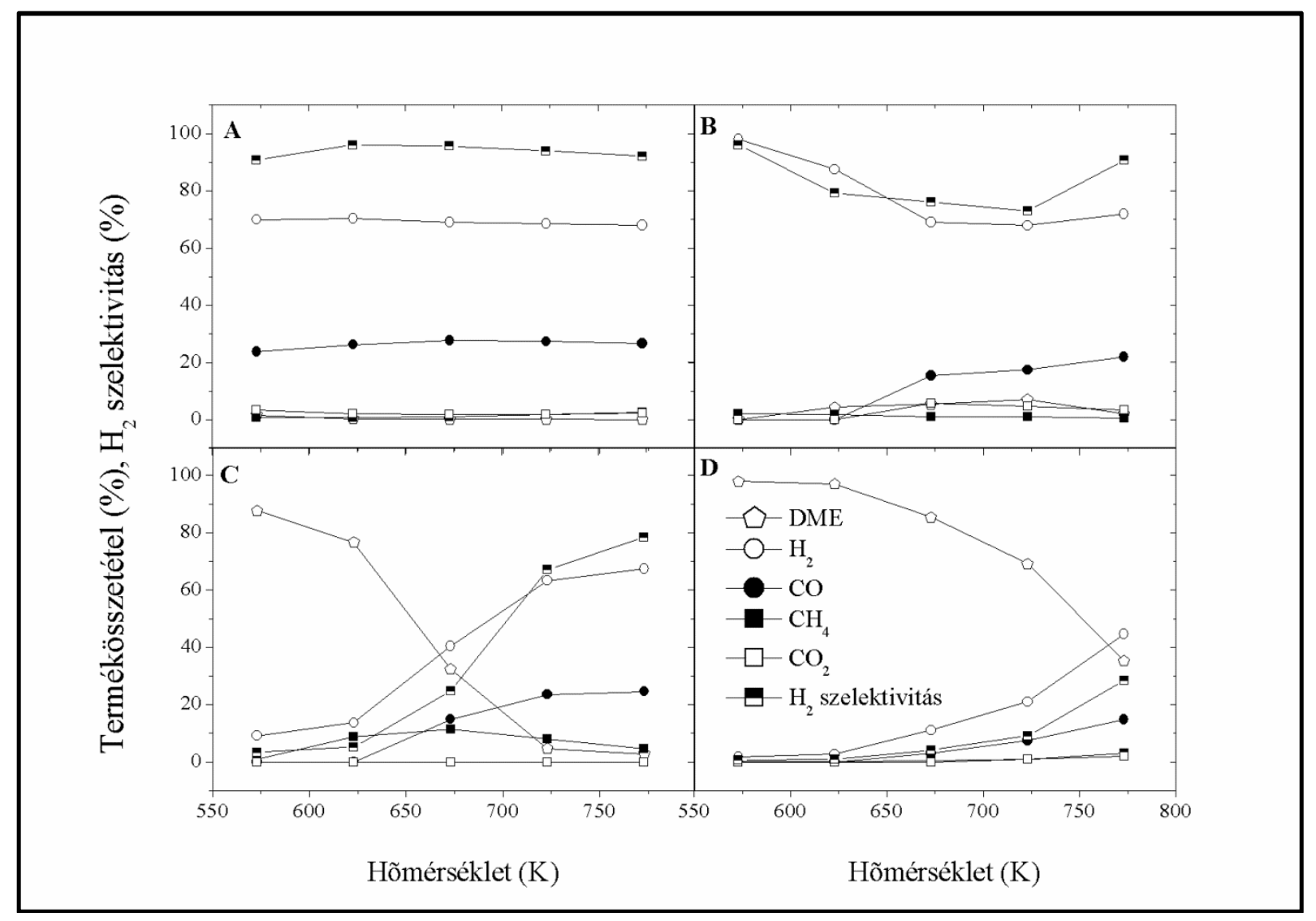

10. ábra $A$ metanol bomlása során képzödött termékek százalékos összetétele és a hidrogén szelektivitás $1 \% \mathrm{Au} / \mathrm{CeO}_{2}$-on (A), $1 \% \mathrm{Au} / \mathrm{MgO}$-on (B), $1 \% \mathrm{Au} /$ noriton (C) és $1 \% \mathrm{Au}^{\mathrm{A}} \mathrm{Al}_{2} \mathrm{O}_{3}$-on (D) különbözö hömérsékleteken 
Magasabb hőmérsékleteken a $\mathrm{H}_{2}$ és a $\mathrm{CO}$ a fö termék, ezek mellett kaptunk nagyon kis mennyiségü DME-t és metánt. Ennek eredményeképpen a hidrogén képződés szelektivitása a legtöbb esetben elérte a $80 \%$-ot $773 \mathrm{~K}$-en. A nagyon aktív 1\% $\mathrm{Au} / \mathrm{Al}_{2} \mathrm{O}_{3}$ katalitikus viselkedése eltér a többitől, a dehidratációs tulajdonságának következtében a DME volt a domináns termék az egész reakció alatt. Még $773 \mathrm{~K}$-en is több mint 30\%-ban van jelen a termékek között (10.D ábra). A $\mathrm{H}_{2}$ szelektivitás $30 \%$ alatt maradt még $773 \mathrm{~K}$-en is. Az $\mathrm{Au} / \mathrm{TiO}_{2}$-n a $\mathrm{DME}$ és a $\mathrm{CH}_{4}$ volt a fö termék a vizsgált hőmérséklettartományon belül (573$773 \mathrm{~K})$. A kapott termék csak $20 \% \mathrm{H}_{2}$-t tartalmazott. Ezen a hőmérsékleten hosszabb ideig figyelve a bomlást, a hidrogénképződés növekedett a metán rovására, viszont a hidrogén szelektivitása csak $21 \%$-ot ért el még 8 óra alatt is.

Annak érdekében, hogy a különböző arany minták katalitikus viselkedését összehasonlítsuk, ábrázoltuk a $\mathrm{H}_{2}$ hozamát a 9. ábra a reakció hőmérsékletének függvényében. Tisztán látszik, hogy az $\mathrm{Au} / \mathrm{CeO}_{2}$ messze a legaktívabb katalizátor. Ez a hatékonyság tovább fokozható, ha az arany tartalmat 5\%-ra növeljük. Ebben az esetben a metanol konverziója több mint 90\% volt már $673 \mathrm{~K}$-en és a teljes bomlást $723 \mathrm{~K}$-en értük el. Ez összefüggésben van azzal, hogy nagyon magas a hozam, mivel a nagy konverzió mellett több mint 90\% képződött hidrogént kaptunk. Megjegyezzük, hogy a tiszta $\mathrm{CeO}_{2}$ is mutatott katalitikus aktivitást a metanol bomlásában $673 \mathrm{~K}$ felett, de messze nem volt olyan aktív, mint az Au-tartalmú minták, különösen a hidrogéntermelésben. A katalitikus jellemzök összehasonlítására szolgáló jellegzetes adatok a tiszta és az arany tartalmú $\mathrm{CeO}_{2}$-ra vonatkozóan a 4. táblázatban lettek bemutatva.

4. táblázat: A metanol bomlására jellemzö adatok a tiszta $\mathrm{CeO}_{2}$ és az $1 \% \mathrm{Au} / \mathrm{CeO}_{2}$ katalizátorokon

\begin{tabular}{llllllllll}
\hline $\begin{array}{l}\text { Katalizátor } \\
\text { (673 K-en } \\
\text { redukálva) }\end{array}$ & $\begin{array}{l}\text { Konverzió } \\
(\%)\end{array}$ & $\begin{array}{l}\mathbf{H}_{2} \\
\text { szelektivitás } \\
(\%)\end{array}$ & $\begin{array}{l}\mathbf{H}_{2} \\
\text { hozam }\end{array}$ & $\begin{array}{l}\mathbf{H}_{2} / \mathbf{C O} \\
\text { arány }\end{array}$ & $\begin{array}{l}\text { Konverzió } \\
(\%)\end{array}$ & $\begin{array}{l}\mathbf{H}_{2} \\
\text { szelektivitás } \\
(\%)\end{array}$ & $\begin{array}{l}\mathbf{H}_{2} \\
\text { hozam }\end{array}$ & $\begin{array}{l}\mathbf{H}_{2} / \mathbf{C O} \\
\text { arány }\end{array}$ \\
\hline $\mathbf{C e O}_{2}$ & 4,9 & 51,1 & 2,5 & 2,3 & 90,2 & 62,7 & 57,9 & 2,8 \\
\hline $\begin{array}{l}\mathbf{1 \%} \\
\mathbf{A u} / \mathbf{C e O}_{2}\end{array}$ & 55,0 & 95,6 & 38,5 & 2,5 & 90,7 & 90,1 & 81,7 & 2,6 \\
\hline $\begin{array}{l}\mathbf{5 \%} \\
\mathbf{A u} / \mathbf{C e O}_{2}\end{array}$ & 91,9 & 95,1 & 90,4 & 2,6 & 100,0 & 93,2 & 93,2 & 2,6 \\
\hline
\end{tabular}


A legaktívabb $1 \% \mathrm{Au} / \mathrm{CeO}_{2}$ katalizátoron kinetikai méréseket is végeztünk alacsony konverzióknál. A metanol parciális nyomását változtattuk, miközben a teljes áramlási sebességet $60 \mathrm{ml} / \mathrm{min}$ értéken tartottuk inert argon gázt adva a rendszerhez ballasztként. A metanol reakciója ilyen körülmények között első rendü kinetikát követett. Az aktiválási energiák meghatározását 565-645 K között hajtottuk végre. A metanol konverziója 2 és 12\% között volt. Az Arrhenius egyenesekből 76,7 kJ/mol aktiválási energiát kaptunk a hidrogén képződésére és $87,5 \mathrm{~kJ} / \mathrm{mol}-\mathrm{t}$ a CO-ra.

\subsubsection{Metanol reformálása}

Vizet adva a reakcióhoz $\left(\mathrm{CH}_{3} \mathrm{OH} / \mathrm{H}_{2} \mathrm{O}=1: 1\right)$ csak kis mértékben befolyásolta a konverzió értékeket $\mathrm{Au} / \mathrm{CeO}_{2}$-on, de jelentős volt a változás a termékképződést illetően. $\mathrm{A}$ relatív hidrogén tartalom 68\%-ról 75\%-ra nőtt és a CO 27\%-ról 17\%-ra csökkent $773 \mathrm{~K}$-en. Ezzel egy időben a $\mathrm{CO}_{2}$ képződés elérte a 7\%-ot. A DME és a formaldehid alacsony hömérsékleten szintén kevesebb mértékben képződött.

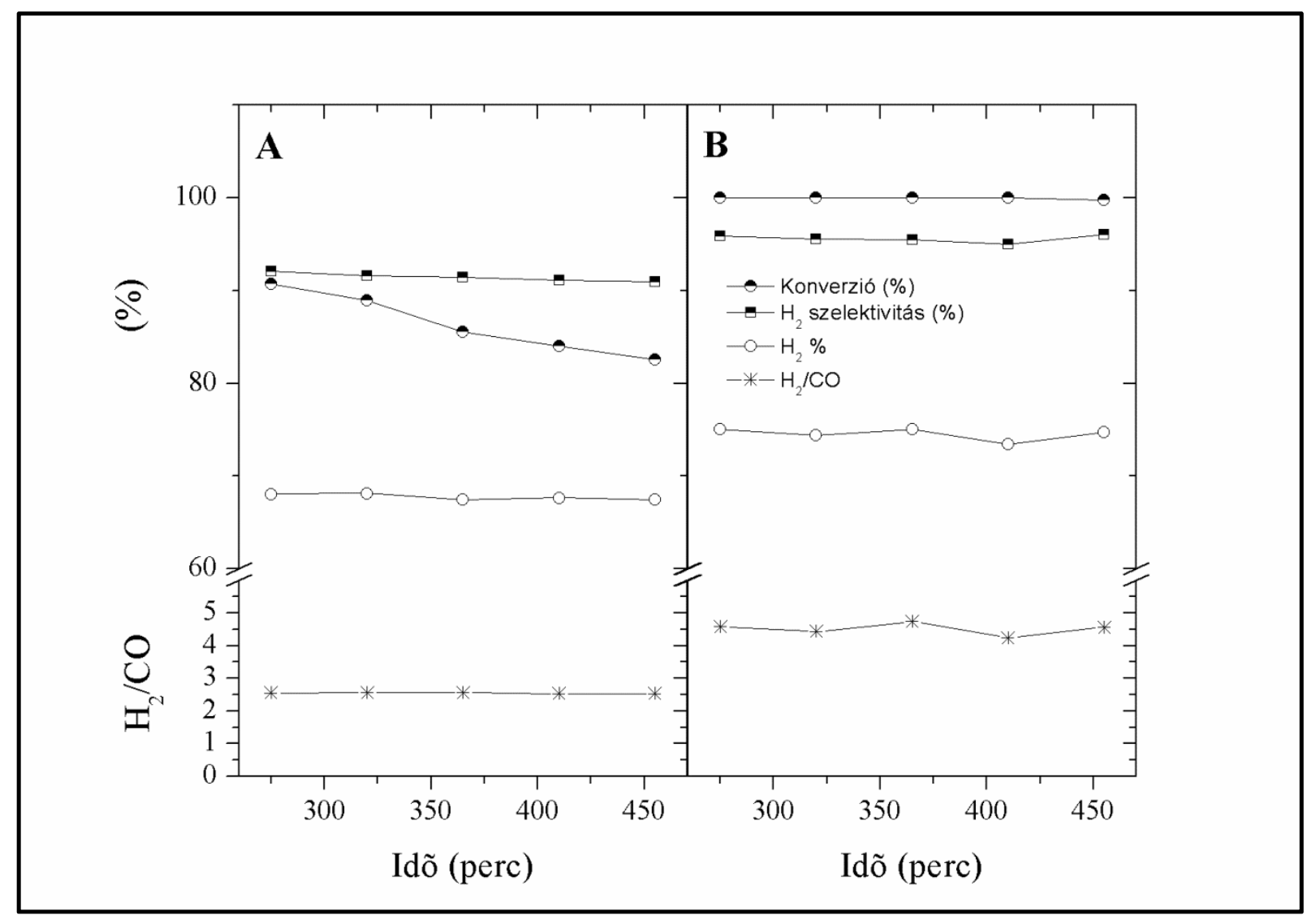

11. ábra Metanol bontása (A) és viz reformálása $\left(\mathrm{CH}_{3} \mathrm{OH}: \mathrm{H}_{2} \mathrm{O}=1: 1\right)$ (B) $1 \% \mathrm{Au} / \mathrm{CeO}_{2}$-on $773 \mathrm{~K}$-en. 
Mindennek eredményeként a hidrogén szelektivitás 623-773 K között 96-97\% volt. Ebben az esetben a metanol bomlás magasabb stabilitást mutatott az alkalmazott katalizátorokon (11. ábra).

Hasonló változást tapasztaltunk a termék összetételében $1 \% \mathrm{Au} / \mathrm{MgO}$-on. A hidrogén szelektivitás 95-97\%-ra nőtt, viszont a konverzió csak 30\%-ot ért el 773K-en, így a $\mathrm{H}_{2}$ hozam kevesebb lett, mint 30\%. A víztartalom növelése $\left(\mathrm{CH}_{3} \mathrm{OH} / \mathrm{H}_{2} \mathrm{O}=1: 3\right)$ több képződött hidrogént eredményezett és némi növekedést a hidrogén szelektivitásban mindkét mintán. Nagy figyelmet fordítottunk az $\mathrm{Au} / \mathrm{Al}_{2} \mathrm{O}_{3}$ viselkedésére. Azt vártuk, hogy a víz jelenléte kimozdítja az egyensúlyt és lecsökkenti a dehidratációs reakciót. Összhangban az elvárásokkal kevesebb lett a DME mennyisége és több a képződött hidrogén a termékben: de a hozzáadott víz hatása nem volt jelentős. A $\mathrm{CH}_{3} \mathrm{OH} / \mathrm{H}_{2} \mathrm{O}=1: 1$ elegynél a hidrogén szelektivitás 27\%-ról 37-40\%-ra nőtt, ennek a legkedvezőbb hőmérséklet 773 K volt.

\subsubsection{In situ FTIR vizsgálatok}

A 12.A ábra azonos körülmények között felvett IR spektrumokat mutat be, amik a metanol bomlása közben lettek regisztrálva $1 \% \mathrm{Au} / \mathrm{CeO}_{2}$-on különböző reakció hőmérsékleteken. A C-H nyújtási tartományban jól detektálható sávokat találtunk 2,981; 2,935-2,938; 2,923; 2,844 és 2,810 $\mathrm{cm}^{-1}$-nél. Az alacsonyabb hullámszám tartományban is figyeltünk meg intenzív sávokat 1,$600 ; 1,575 ; 1,371 ; 1,330 ; 1,061$ és $1,032 \mathrm{~cm}^{-1}$-nél. A hőmérsékletet fokozatosan emelve 573 K-ről 773 K-re, megfigyelhető változás csak az 1,600 $\mathrm{cm}^{-1}$-nél lévő sáv eltűnésében és az $1,416 \mathrm{~cm}^{-1}$-nél egy új spektrális tulajdonság fejlődésében volt. A kép nem változott jelentősen ezen a katalizátoron a metanol + víz (1:1) reakciójában. Hasonló spektrumot kaptunk tiszta $\mathrm{CeO}_{2}$-on egy csekély eltéréssel az abszorpciós sávok helyzetében (12.B ábra). $\mathrm{Az} 1 \% \mathrm{Au} / \mathrm{MgO}$ vizsgálata során kapott eredmények a 12.C ábrán láthatóak. Ebben az esetben a magas frekvencia tartományában azonos spektrális jelleget figyeltünk meg, mint a $\mathrm{CeO}_{2}$ hordozós minták esetében. Az alacsony frekvencia tartományban viszont az 1,575 és az $1,371 \mathrm{~cm}^{-1}$ csúcsok hiányoznak. 


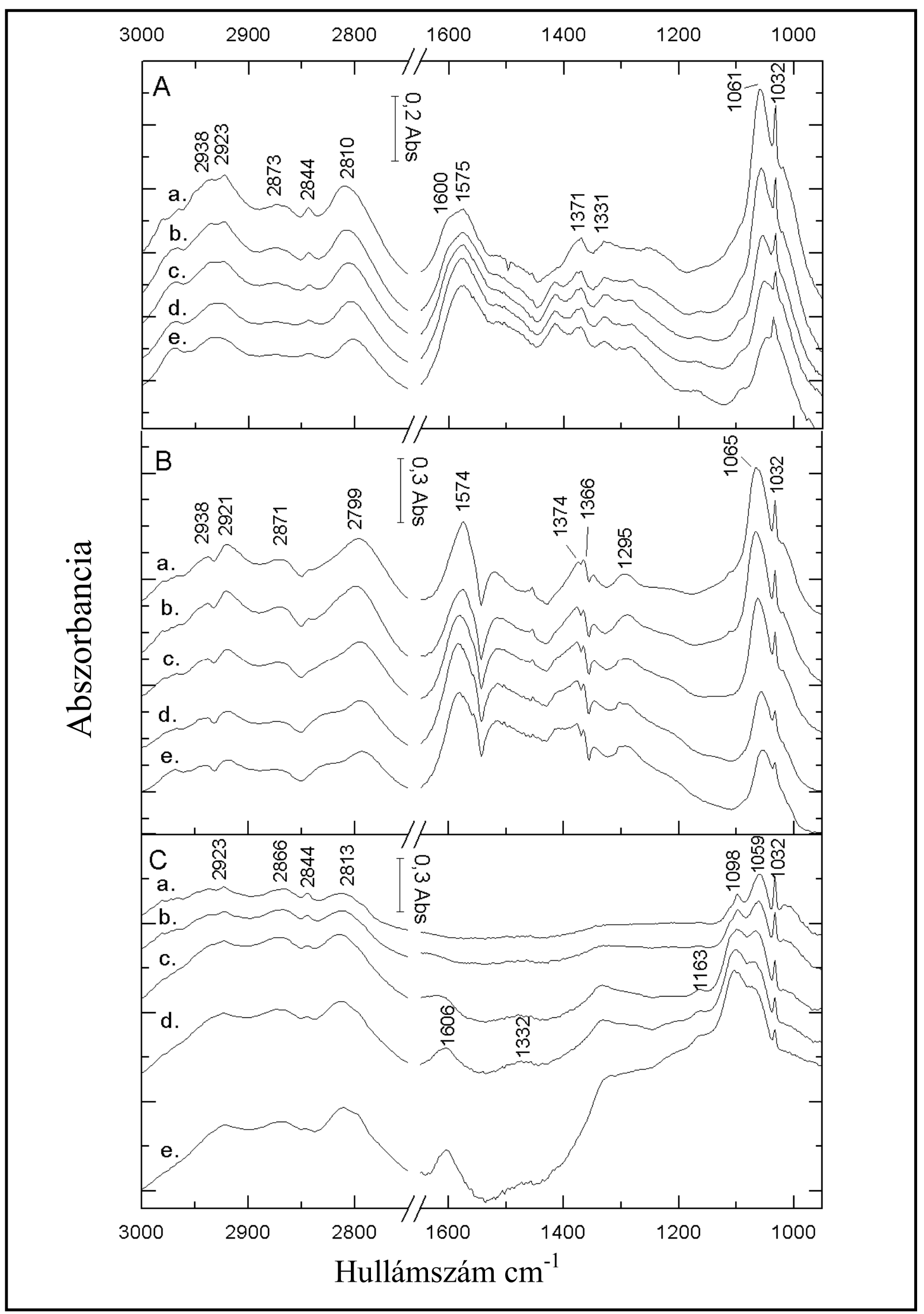

12. ábra: In situ IR spektrumok $1 \% \mathrm{Au} / \mathrm{CeO}_{2}(\mathrm{~A}), \mathrm{CeO}_{2}(\mathrm{~B})$ és $1 \% \mathrm{Au} / \mathrm{MgO}$-on (C) a metanol bomlása során 573-773K között. (a) $573 \mathrm{~K}$, (b) $623 \mathrm{~K}$, (c) $723 \mathrm{~K}$, (d) $723 \mathrm{~K}$, (e) $773 \mathrm{~K}$. 


\subsubsection{Eredmények értelmezése}

A metanol adszorpciója és deszorpciója során kapott eredmények értelmezése előtt beszéljünk először a legfontosabb felfedezésekről a metanol és a fém egykristály felületek kölcsönhatásának vizsgálatakor, ami számos kutatás témája volt. Általánosan elfogadott, hogy a metanol disszociációjának fó útja Pt-fémeken az O-H kötés szakadás, ami metoxi-csoport képződésével jár ${ }^{100-105}$. Viszont az XPS, SIMS és TPD-re alapozott eredmények a bimolekuláris mechanizmust javasolják,

$$
2 \mathrm{CH}_{3} \mathrm{OH}_{(\mathrm{a})}=\mathrm{CH}_{3} \mathrm{O}_{(\mathrm{a})}+\mathrm{CH}_{3(\mathrm{a})}+\mathrm{H}_{2} \mathrm{O}_{(\mathrm{g})}
$$

amelyben a két szomszédos adszorbeált metanol molekula hoz létre egy metoxi csoportot, egy metil csoportot és egy víz molekulát a felületen ${ }^{106}$. Ez a javaslat széleskörü vitát váltott ki az irodalomban, ami arra enged következtetni, hogy a metanol disszociációjának ez az új útja nem teljesen utasítható el ${ }^{107-110}$. A tömbi arany sokkal kevésbé reaktív a metanol iránt, mint a Pt fémek: nincs bizonyíték a metanol disszociációjára 100 K-re való fütése után az adszorbeált metanolnak tiszta $\mathrm{Au}(111)-\mathrm{n}^{111,112}$. Méréseink során oxigént adszorbeáltattunk a felületre, feltételezve, hogy az oxigén atomok támogatják a metanol disszociációt és a metoxicsoport képződését, de ezt nem tudtuk kimutatni vibrációs spektroszkópiával. Sokkal nagyobb reaktivitást vártunk el az arany nanorészecskéktől, amit azt számos reakcióban is mutattak $^{2,12,25-32}$.

A metanol adszorpciójának FTIR tanulmányozása tiszta cérium-dioxidon és $\mathrm{CeO}_{2}$ hordozós katalizátorokon számos kutatás témája volt ${ }^{36,37,94-99}$. Metoxi-csoportokat adszorbeáltattak a $\mathrm{CeO}_{2}$ felületére, ennek eredményeként különböző felületi formákat találtak: egyszeresen koordinált $\left(\mathrm{Ce}-\mathrm{OCH}_{3}\right)$, kétszeres kapcsolódást $\left(\mathrm{Ce}_{2}-\mathrm{OCH}_{3}\right)$ vagy háromszoros kapcsolódást $\left(\mathrm{Ce}_{3}-\mathrm{OCH}_{3}\right)$ különböztettek meg ${ }^{95}$. A korábbi tanulmányok eredményeire alapozva (3. táblázat) az $\mathrm{Au} / \mathrm{CeO}_{2}$ esetében 2,915 és 2,809 $\mathrm{cm}^{-1}$-nél megjelenő jelentősebb sávok az aszimmetrikus és a szimmetrikus kötésnyúlási rezgéshez rendelhetőek, míg az 1,100 és $1,048 \mathrm{~cm}^{-1}$-es csúcsok a vibrációs vagy a $\mathrm{CH}_{3} \mathrm{O}$-csoport $v(\mathrm{OC})$ vegyértékrezgése (7.B ábra). Gyakorlatilag ugyanolyan spektrumot kaptunk a tiszta $\mathrm{CeO}_{2}$ esetében is (7.A ábra), amiből arra következtethetünk, hogy az adszorbeálódott metoxi csoport a hordozóhoz kapcsolódik. Megjegyezzük, hogy volt spektrális jele a 10. reakcióban képződött adszorbeált 


\section{Mérési eredmények bemutatása és értelmezése}

metil csoportnak, aminek jelenlétét az alábbi adszorpciós sávok mutatják 2,920-2,945; 1,3401,356 és 1,175-1,195 $\mathrm{cm}^{-1}$-nél $\mathrm{Rh}(111)$-en és $\mathrm{TiO}_{2}$ felületen ${ }^{113,114}$. Drámai változás következik be mind a magas mind az alacsony frekvencia tartományban $\mathrm{Au} / \mathrm{CeO}_{2}$-on $373 \mathrm{~K}$ körül, viszont ezt a változást az adszorpciós rétegben nagyon valószínü, hogy az arany idézi elő. Ennek oka lehet az adszorbeált $\mathrm{CH}_{3} \mathrm{O}$ koordinációjában bekövetkező változás vagy más felületi formák képződésének az eredménye. Egy másik feltevés az intenzív új sávok megjelenésére $373 \mathrm{~K}$ körül a formaldehid képződése,

$\mathrm{CH}_{3} \mathrm{O}_{(\mathrm{a})}=\mathrm{CH}_{2} \mathrm{O}_{(\mathrm{a})}+\mathrm{H}_{(\mathrm{a})}$

amelyre jellemző vibrációs sávok 2,846; 2,722 és $1,596 \mathrm{~cm}^{-1}$-nél figyelhetőek meg és/vagy a formiát csoport képződése

$\mathrm{OH}_{(\mathrm{a})}+\mathrm{CO}_{(\mathrm{g})}=\mathrm{HCOO}_{(\mathrm{a})}$

amelynek jelenlétét 2,932; 1,570; 1,370 és $1,359 \mathrm{~cm}^{-1}$-nél lévő adszorpciós sávok jelzik (3. táblázat).

Az arany szerepe a TPD spektrumokból is kiolvasható. Amiben arany hatására nem csak a metanol deszorpciójának növekedése jelenik meg, de a termékek képződésének a növekedése is. Feltételezhetjük, hogy mind a metoxi képződése és ennek továbbalakulása más felületi vegyületekké növekedik az aktív $\mathrm{Au} / \mathrm{CeO}_{\mathrm{x}}$ határfelülettel. Ezen túlmenően az adszorbeált csoportok velejárója a cérium-dioxid hordozón, hogy vándorolnak az aktív helyek felé.

A hordozós Au katalizátorok különféle katalitikus viselkedést mutatnak az alkalmazott hordozótól függően. Míg a metanol nagy mértékben reagált $\mathrm{Au} / \mathrm{CeO}_{2}$-on és $\mathrm{Au} / \mathrm{Al}_{2} \mathrm{O}_{3}$-on, addig $\mathrm{Au} / \mathrm{SiO}_{2}$-on és $\mathrm{Au} /$ norit katalizátorokon nagyon kicsi aktivitást figyeltünk meg. $\mathrm{Az}$ $\mathrm{Au} / \mathrm{MgO}$ és $\mathrm{Au} / \mathrm{TiO}_{2}$ mérsékelt aktivitást mutatott. Köztudott, hogy az alumínium-oxid erös Brönstead savként igen aktív a metanol dehidratációjában.

$2 \mathrm{CH}_{3} \mathrm{OH}=\left(\mathrm{CH}_{3}\right)_{2} \mathrm{O}+\mathrm{H}_{2} \mathrm{O}$ 
Habár az alumínium-oxidon adszorbeált arany nanorészecskék befolyásolják a reakcióutat, amely hidrogénképződéshez vezet, különösen magas hőmérsékleteken, viszont a hidrogén tartalom és a szelektivitás nem volt több, mint 30 és $28 \% 773 \mathrm{~K}$ körül.

$\mathrm{Az} \mathrm{Au} / \mathrm{CeO}_{2}$ nagy aktivitásának magyarázatában egy fontos tényező, hogy a tiszta $\mathrm{CeO}_{2}$ szintén katalizálja a metanol bomlását (4. táblázat). Ez a katalitikus hatás azonban csak magas hőmérsékleten jelentkezett (723-773 K), ekkor már a hidrogén hozam is elérte a 60\%ot. $673 \mathrm{~K}$-en a metanol konverziója csak 5\% volt, míg az 5\% $\mathrm{Au} / \mathrm{CeO}_{2}$-on több mint $90 \%$-ot mértünk. Mindezek a tulajdonságok egyértelmüen arra utalnak, hogy kölcsönhatás van az Au nanorészecskék és a $\mathrm{CeO}_{2}$ hordozó között. Feltételezhetjük, hogy az $\mathrm{Au} / \mathrm{CeO}_{2}$ nagyon aktív centrumokat tartalmaz. Ez feltehetőleg az $\mathrm{Au}$ és a részlegesen redukált $\mathrm{CeOx}$ közötti határfelületen van, ahol egy elektromos kölcsönhatás jön létre az $\mathrm{Au}$ és az n-tipusú $\mathrm{CeO}_{2}$ félvezető között. Ezt a jelenséget először a Ni és az n-tipusú $\mathrm{TiO}_{2}$ között figyelték meg ${ }^{77,78}$. Bár további vizsgálatok szükségesek ennek az érdekes jelenségnek a tisztázására, figyelembe véve a könnyü metoxi képződést a metanol adszorpciójának és reakciójának tanulmányozása során szilárd felületen (3. táblázat, 7. ábra, 12. ábra), nagyon valószínü, hogy a metoxi csoportban az egyszeres C-H kötés szakadása

$\mathrm{CH}_{3} \mathrm{O}_{(\mathbf{a})}=\mathrm{CH}_{2} \mathrm{O}_{(\mathrm{a})}+\mathrm{H}_{(\mathbf{a})}$

a sebesség meghatározó lépés a metanol bomlása során.

Víz hozzáadása a metanolhoz megváltoztatta a termék összetételét és a hordozó természetétől függően növelte a hidrogénképződést különböző mértékben. A legjobb eredményt ismét az $\mathrm{Au} / \mathrm{CeO}_{2}$ katalizátoron kaptuk, ebben az esetben tapasztaltuk a legnagyobb hidrogén növekedést és a CO tartalom csökkenését a termékekben. Ezt a változást leginkább a hidrogén tartalmú vegyületek alapján számolt hidrogén szelektivitássa és a hidrogén hozam értékekkel lehet szemléltetni. Ez utóbbi elérte a 97\%-ot víz jelenlétében. Az elért eredmény az $\mathrm{Au} / \mathrm{CeO}_{2}$ víz-gáz reakcióban való hatékonyságának tulajdonítható. A víz jelenléte kevésbé volt hatással a hidrogénképződésre Au/noriton, nagyon valószínű, hogy ez az aktív $\mathrm{OH}$ csoprtok hiányának tulajdonítható, amelyet a víz-gáz reakció lejátszódása megkövetelne. 


\section{Mérési eredmények bemutatása és értelmezése}

\subsubsection{Föbb konklúziók}

(i) Az arany nanorészecskék katalitikus tulajdonsága a metanol bomlásában és a reformálásában érzékenyen függ a hordozó természetétől. A legmagasabb aktivitást mindkét reakcióban az $\mathrm{Au} / \mathrm{CeO}_{2}$ katalizátoron mértük és a legalacsonyabbat az $\mathrm{Au} / \mathrm{SiO}_{2}$-on. $\mathrm{Au} / \mathrm{Al}_{2} \mathrm{O}_{3}$-on a jellemző reakcióút a dehidratációs reakció volt.

(ii) Az infravörös mérések kimutatták a metoxi csoport képződést mind az aranyon mind $\mathrm{CeO}_{2}$ hordozón is.

(iii) A metanol reformálását szintén katalizálta az $\mathrm{Au} / \mathrm{CeO}_{2}$ 96-97\%-os $\mathrm{H}_{2}$ yielddel. Nem volt tapasztalható a katalizátor dezaktiválódása 10 óra reakció idő elteltével sem. 


\subsubsection{Etanol vizsgálata}

\subsubsection{Infravörös spektroszkópiás mérések}

13. ábra mutatja az IR spektrumait az $1 \% \mathrm{Au} / \mathrm{CeO}_{2}$-on $300 \mathrm{~K}$-en adszorbeált etanolnak, majd ezt követően különböző hőmérsékletre felfütve folyamatos szívatás közben. 300 K-en intenzív abszorpciós sávokat figyeltünk meg 2961, 2923, 2867, $2712 \mathrm{~cm}^{-1}$-nél a CH-rezgési tartományban. Alacsonyabb frekvenciáknál 1461, 1410, 1387, 1338, 1279, 1101 és $1054 \mathrm{~cm}^{-1}$-nél azonosítottunk sávokat. A minta fütése valamennyi sáv csökkenését okozta, valamint új spektrális változás is megjelent $1620 \mathrm{~cm}^{-1}$-nél, amelynek intenzitása $573 \mathrm{~K}$-ig növekedett majd a hőmérséklet további emelésével csökkent.

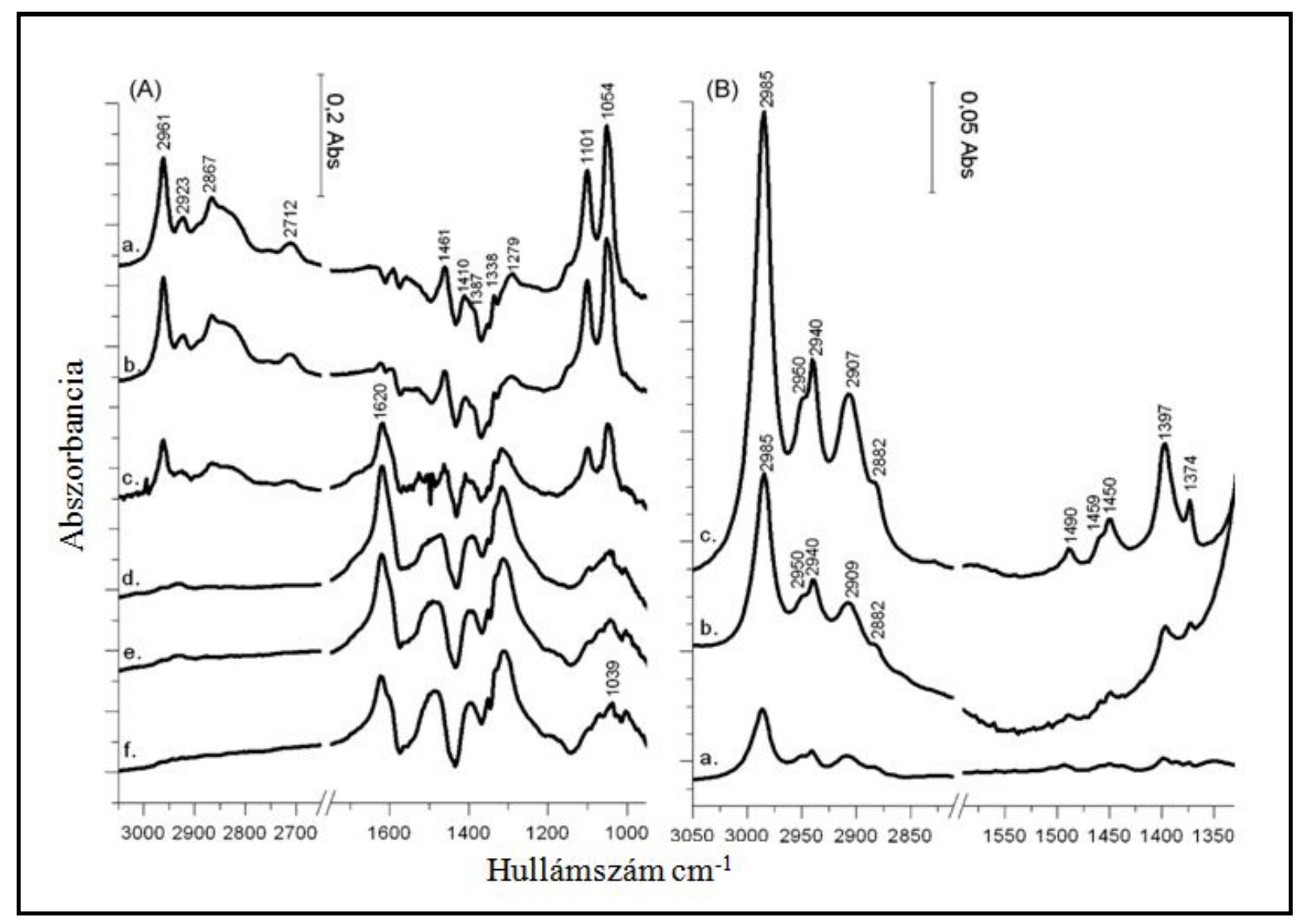

13. ábra $\mathrm{Az}$ etanol $300 \mathrm{~K}$-en történö adszorpcióját követö FTIR spektrumok $1 \% \mathrm{Au} / \mathrm{CeO}_{2}$-on (A) és folyamatos szívatás közben különbözö hömérsékleteken: (a) $300 \mathrm{~K}$, (b) $373 \mathrm{~K}$, (c) $473 \mathrm{~K}$, (d) $573 \mathrm{~K}$, (e) $673 \mathrm{~K}$, (f) $773 \mathrm{~K}$. (B) FTIR spektrumok $\mathrm{SiO}_{2}-n$ (a), 1\% Au/SiO $\mathrm{S}_{2}$ (b) és 5\% Au/SiO${ }_{2}-n$ (c) $300 \mathrm{~K}$-en történö adszorpciót követö $473 \mathrm{~K}$-re történö felfütés után folyamatos szívatás közben 
5. táblázat $\mathrm{Az}$ etanol különbözö CeO $\mathrm{O}_{2}$ hordozós katalizátorokon $300 \mathrm{~K}$-en történö adszorpciója során képzödött etoxi csoportok IR rezgései

\begin{tabular}{lccccccc}
\hline $\begin{array}{l}\text { Jellemzó } \\
\text { rezgések }\end{array}$ & $\mathbf{C e O}_{\mathbf{2}}{ }^{\mathbf{1 1 5}}$ & $\begin{array}{c}\mathbf{C e O}_{\mathbf{2}} \\
\text { (jelen } \\
\text { munka) }\end{array}$ & $\begin{array}{c}\mathbf{R h} / \mathbf{C e O}_{\mathbf{2}} \\
\mathbf{1 1 6}\end{array}$ & $\begin{array}{c}\mathbf{P t} / \mathbf{C e O}_{\mathbf{4 7}} \\
\mathbf{A u} / \mathbf{C e O}_{\mathbf{5 2}}\end{array}$ & $\begin{array}{c}\mathbf{A u} / \mathbf{C e O}_{2} \\
\text { (jelen } \\
\text { munka) }\end{array}$ & $\begin{array}{c}\mathbf{A u} / \mathrm{SiO}_{2} \\
\text { (jelen } \\
\text { munka) }\end{array}$ \\
\hline$v_{\text {as }}\left(\mathrm{CH}_{3}\right)$ & 2960 & 2966 & 2981 & 2981 & 2971 & 2961 & 2985 \\
$v_{\text {as }}\left(\mathrm{CH}_{2}\right)$ & - & 2927 & 2934 & - & 2933 & 2923 & 2940 \\
$v_{\mathrm{s}}\left(\mathrm{CH}_{3}\right)$ & 2836 & 2896 & 2911 & 2896 & 2904 & - & 2907 \\
$v_{\mathrm{s}}\left(\mathrm{CH}_{2}\right)$ & - & - & 2878 & 2872 & 2875 & 2867 & 2882 \\
$\delta_{\text {as }}\left(\mathrm{CH}_{2}\right)$ & 1473 & 1447 & 1478 & - & 1478 & - & 1490 \\
$\delta_{\text {as }}\left(\mathrm{CH}_{3}\right)$ & - & - & 1450 & 1445 & 1449 & 1461 & 1450 \\
$\delta_{\mathrm{s}}\left(\mathrm{CH}_{3}\right)$ & 1383 & - & 1399 & 1391 & 1399 & 1387 & 1397 \\
$\delta_{\mathrm{s}}\left(\mathrm{CH}_{2}\right)$ & - & 1297 & - & 1264 & 1362 & - & 1374 \\
$\omega\left(\mathrm{CH}_{2}\right)$ & - & - & - & - & 1333 & - & - \\
$v(\mathrm{OC})$ mono- & 1107 & 1114 & 1080 & 1100 & 1109 & 1101 & - \\
$v(\mathrm{OC}) / v(\mathrm{CC})$ & - & 1064 & - & 1072 & 1065 & 1084 & - \\
$v(\mathrm{OC})$ bi- & 1057 & 1048 & 1038 & 1042 & 1038 & - & - \\
\hline
\end{tabular}

Látszólag azonos spektrumot kaptunk az etanol $\mathrm{CeO}_{2}$-on történő adszorpciójakor azzal a különbséggel, hogy az 1620-as sáv ebben az esetben nem volt detektálható. Hasonló spektrális jegyeket találtunk az $\mathrm{Au} / \mathrm{Al}_{2} \mathrm{O}_{3}$ és $\mathrm{Au} / \mathrm{MgO}$-nál is. $\mathrm{Az} \mathrm{Au} / \mathrm{SiO}_{2}$-on kapott eredmények külön említést érdemelnek. Ennek a mintának az előnye az, hogy az etanol adszorpciójakor gyenge sávok jelennek meg az inert hordozón ${ }^{117}$, valamint az etoxi csoportok képződése nagyon korlátozott a tiszta hordozón, így az várható hogy az észlelt rezgési sávok az $\mathrm{Au}$ részecskékhez kötődő csoportoknak tulajdoníthatóak. Annak érdekében, hogy kiküszöböljük a gyengén kötődő etanoltól származó spektrális jelleget, az adszorpciós réteget folyamatos szívatás mellett $473 \mathrm{~K}$-re fütöttük fel. A TPD kísérletek (5.2.2.2.) kimutatták, hogy ez a hőkezelés elegendő az etanol deszorpciójához. A vártnak megfelelően a tiszta $\mathrm{SiO}_{2}$ IR spektruma csak nagyon gyenge sávokat eredményezett, de az 1\% Au jelenléte jelentős növekedést okozott 2985, 2950, 2940, 2907, 2882, 1490, 1459, 1450,1397, $1374 \mathrm{~cm}^{-1}$ hullámszámoknál, ezeknek az intenzitása tovább fokozódott az arany tartalommal 5\% $\mathrm{Au} / \mathrm{SiO}_{2}$-n, a sávok helyének változása nélkül. Hasonlóan a tiszta $\mathrm{CeO}_{2}-$ hoz a szilícium-oxid hordozók esetében sem jelent meg az $1620 \mathrm{~cm}^{-1}$-nél lévő spektrális jellemző. Megjegyezendő, hogy az $\mathrm{Au} / \mathrm{SiO}_{2}$ kivételével az összes mintán az etanol adszorpciója nagyon jól ismert negatív tulajdonságot okozott az OH frekvencia tartományban 3600-3700 között, mutatva azt, hogy a felszíni $\mathrm{OH}$ csoport, folyamatosan fogy az etanollal elreagálva etoxi csoportot eredményezve. 
$\mathrm{C}_{2} \mathrm{H}_{5} \mathrm{OH}_{(\mathrm{a})}+\mathrm{OH}_{(\mathrm{a})}=\mathrm{C}_{2} \mathrm{H}_{5} \mathrm{O}_{(\mathrm{a})}+\mathrm{H}_{2} \mathrm{O}_{(\mathrm{g})}$

Az 5. táblázat mutatja az etoxi csoport jellemző rezgéseit a különböző hordozókon és azok valószínü megjelenését is.

\subsubsection{Hömérséklet programozott deszorpció}

A 14. ábra mutatja az etanol $300 \mathrm{~K}$-en történő adszorpcióját követő TPD spektrumait.
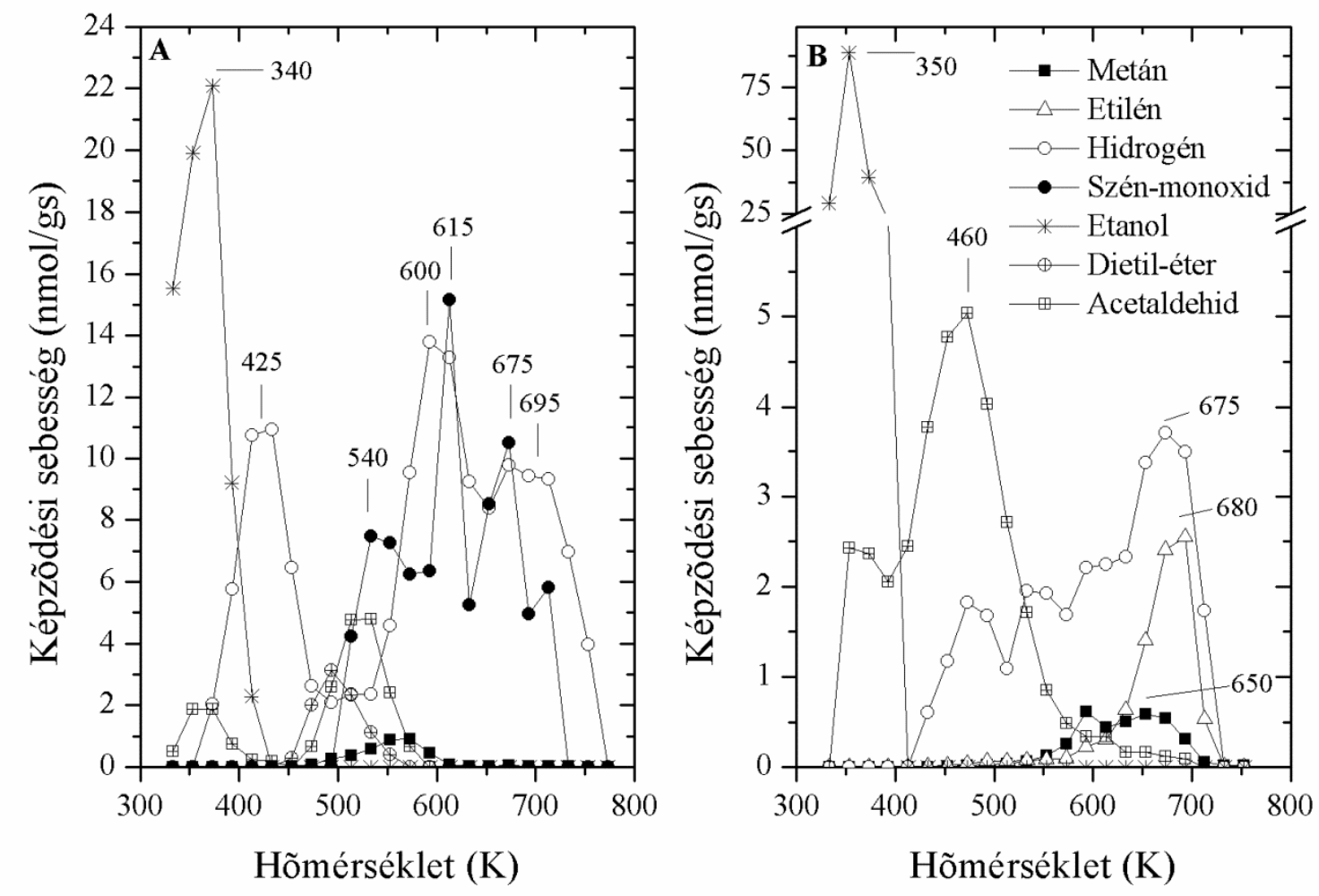

14. ábra $\mathrm{Az}$ etanol $300 \mathrm{~K}$-en történö adszorpcióját követö TPD spektrumok $1 \% \mathrm{Au} / \mathrm{CeO}_{2}$-on (A) és $2 \% \mathrm{Au} / \mathrm{SiO}_{2}-n(\mathrm{~B})$

A tiszta $\mathrm{CeO}_{2}$ esetében az etanol deszorpciója nem sokkal $300 \mathrm{~K}$ fölött kezdődik, és a maximumot 370-400 K-nél éri el. $580 \mathrm{~K}$-en egy kevés hidrogén deszorpciót figyeltünk meg. Ezzel ellentétben különböző vegyületek deszorpciója jelent meg az 1\% Au/ $\mathrm{CeO}_{2}$ mintánál (14. ábra). $\mathrm{Az} 1 \% \mathrm{Au} / \mathrm{CeO}_{2}$ felületéről deszorbeálódott etanol mennyisége lényegében 
megegyezik a tiszta $\mathrm{CeO}_{2}$-nál kapott értékkel. Azonban nagyobb mennyiségü hidrogént tudtunk detektálni különbözö hömérsékletü maximumokkal ( $T_{P}=425,600$ és $\left.695 \mathrm{~K}\right)$. Acetaldehidet $\left(\mathrm{T}_{\mathrm{P}}=530 \mathrm{~K}\right)$, szén-monoxidot $\left(\mathrm{T}_{\mathrm{P}}=540,615\right.$ és $\left.675 \mathrm{~K}\right)$ és kis mennyiségü metánt is megfigyeltünk. Amikor az Au tartalmat 5\%-ra növeltük, ugyanazon vegyületek deszorpcióját tapasztaltuk nagyobb mennyiséggel, de szinte azonos $\mathrm{T}_{\mathrm{P}}$ értékekkel. Számos vegyület deszorbeálódott az $\mathrm{Au} / \mathrm{SiO}_{2}$-ról is: etanol $\left(\mathrm{T}_{\mathrm{P}}=350 \mathrm{~K}\right)$, acetaldehid $\left(\mathrm{T}_{\mathrm{P}}=460 \mathrm{~K}\right)$, hidrogén $\left(T_{P}=460\right.$ és $\left.675 \mathrm{~K}\right)$, metán $\left(T_{P}=650 \mathrm{~K}\right)$ és etilén $\left(T_{P}=680 \mathrm{~K}\right)$ (14. ábra). Ellenőrző méréseket végezve megállapítottuk, hogy a tiszta $\mathrm{SiO}_{2}$ csak gyengén adszorbeálja az etanolt, amely $\mathrm{T}_{\mathrm{P}}=350 \mathrm{~K}$-en deszorbeálódik.

\subsubsection{Etanol bomlása}

A 15. ábra illusztrálja a különböző Au hordozós anyagokon az etanol konverzióját. Az ábrából is jól látszik, hogy az arany katalizátor katalitikus teljesítménye széles spektrumon belül változik a hordozó természetétől függően. A legaktívabb katalizátorokon az 1\% $\mathrm{Au} / \mathrm{Al}_{2} \mathrm{O}_{3}$-on és az $1 \% \mathrm{Au} / \mathrm{CeO}_{2}$-on, a bomlás $475 \mathrm{~K}$ fölött kezdődött el és a teljes konverziót 773 K-en tapasztaltuk. A legkevésbé aktív 1\% Au/MgO-on, a bomlás mértéke csupán 37\% volt még $773 \mathrm{~K}$-en is. Az 573 - $673 \mathrm{~K}$ hőmérséklet tartományban mért konverzió azt mutatja, hogy a katalizátor hatékonysága a következő sorrendben csökken a különböző hordozókon: $\mathrm{Al}_{2} \mathrm{O}_{3}, \mathrm{CeO}_{2}, \mathrm{TiO}_{2}$, norit, $\mathrm{SiO}_{2}, \mathrm{MgO}$. A 15.A ábra mutatja a hidrogénképződés sebességét,

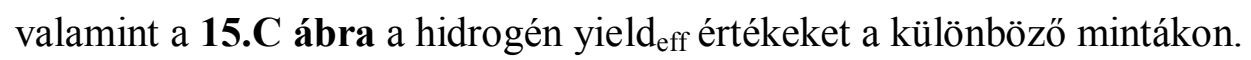

Éles különbségek voltak a katalizátorok között a termékeloszlás tekintetében, ahogyan azt a néhány kiválasztott katalizátor esetében kapott széntartalmú termékek is mutatják (16. ábra). A legaktívabb katalizátor, $\mathrm{az} \mathrm{Al}_{2} \mathrm{O}_{3}$ dehidratációs tulajdonsága a dietil-éter, etilén és víz képződéséhez vezet, hidrogénképződés alig volt detektálható. Ezzel ellentétben az $\mathrm{Au} /$ noriton, amelyet teljesen inaktív anyagnak tartanak az etanol bomlását tekintve, a fó termékek hidrogén és acetaldehid volt. Kis mennyiségü $\mathrm{CO}$-ot és $\mathrm{CH}_{4}$-t is azonosítottunk, főleg $623 \mathrm{~K}$ fölött (16.A ábra). $\mathrm{Az} \mathrm{Au} / \mathrm{SiO}_{2}$-on hidrogén, acet-aldehid, dietil-éter és etilén képződött 573-623 K-en. Magasabb hömérsékleten az acetaldehid mennyisége csökkent, és az etilén valamint az aceton mennyisége nőtt (16.B ábra). A legkevésbé aktív katalizátornak az $\mathrm{Au} / \mathrm{MgO}$ bizonyult, az etanol bomlása $673 \mathrm{~K}$ alatt nagyon gyenge volt (5\%), hidrogén és acetaldehid képződött. 


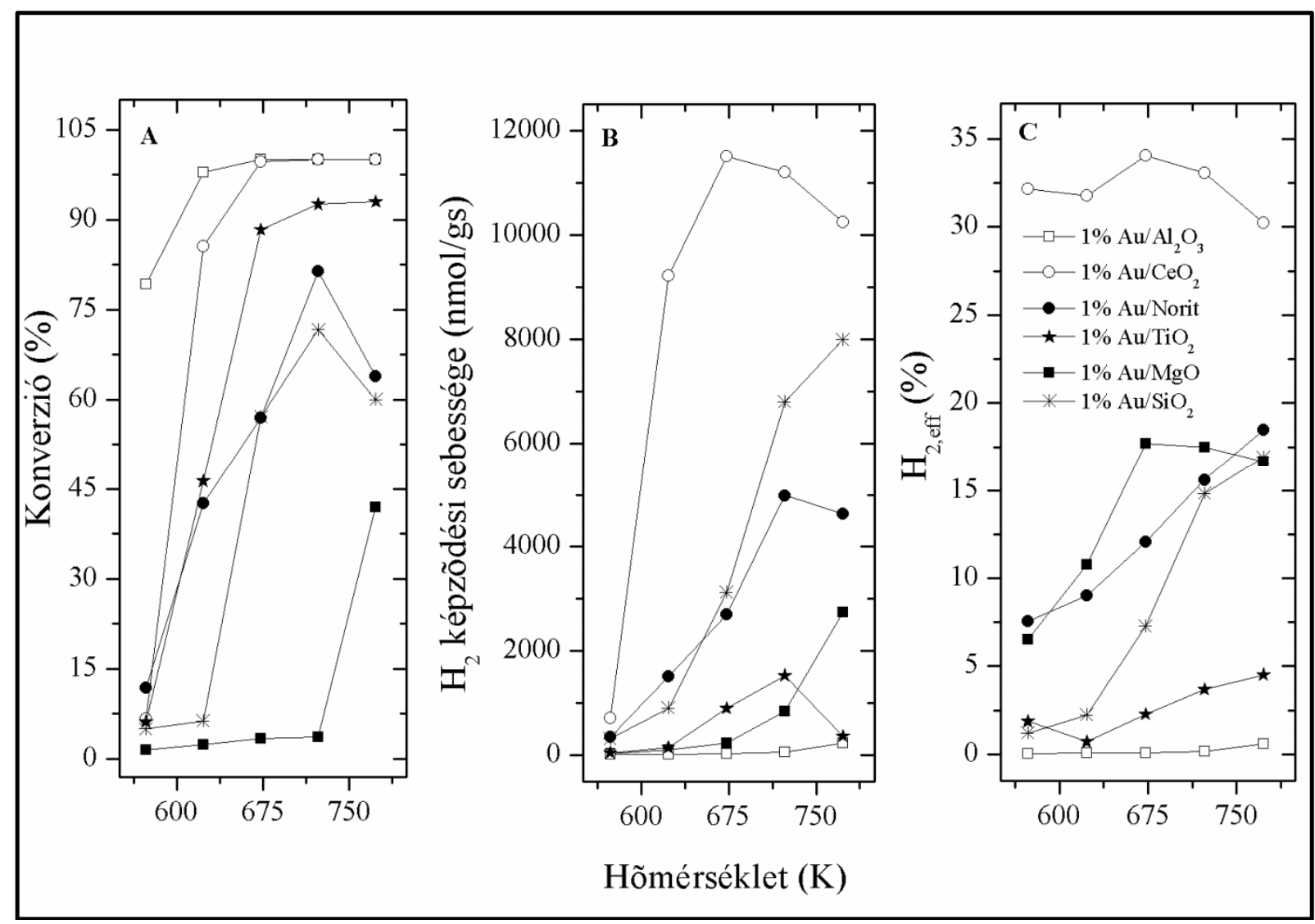

15. ábra Az etanol konverziója (A), a hidrogén képzödési sebessége (B) és a képzödött hidrogén effektív yield értékei (C) különbözö hordozós arany katalizátorokon a hömérséklet függvényében

Nagyon komplex képet kaptunk a $\mathrm{CeO}_{2}$ alapú mintáknál. A tiszta $\mathrm{CeO}_{2}$ az etanol bomlása során a következő termékeket eredményezte $600 \mathrm{~K}$ fölött: hidrogén, etilén, $\mathrm{CO}_{2}$, metán, $\mathrm{CO}$ és acetaldehid, mennyiségük ebben a sorrendben csökken. $\mathrm{A} \mathrm{CeO}_{2}$-ra történő arany rávitele jelentős hatással volt a termék eloszlásra. Habár a hidrogén és az acetaldehid azonos arányban képződött az $1 \% \mathrm{Au} / \mathrm{CeO}_{2}$-on is $573 \mathrm{~K}$-ig, az e fölötti hőmérsékleteken az arány számottevően megváltozott. A hidrogénképződés képződés drámaian növekedett, míg az acetaldehid csökkent. Új termékek megjelenését találtuk: aceton, etilén, metán, 2-pentanon és 3-pentén-2-on, szén-monoxid és kisebb mennyiségben etil-acetát, 2-butanon, 2-butén-1-ol. Nyomnyi mennyiségü 1,3-butadién, toluolt, és 2-heptanont is azonosítottunk. Vízképződést mindegyik katalizátoron tapasztaltunk, de ezek mennyiségét nem határoztuk meg.

Némi figyelmet szenteltünk a 2-pentanon és a 3-pentén-2-on termékekre, amelyet GCMS segítségével is azonosítottunk. Ahogy a 16.C és 16.D ábra mutatja körülbelül $623 \mathrm{~K}$-en kezdődik meg a képződésük és intenzívebbé válnak magasabb hőmérsékleteken. Az arany tartalom szerepe a képződésükben egyértelmüen látszik. Fontos megemlíteni, hogy ezek a 
vegyületek a többi Au tartalmú katalizátoron nem voltak kimutathatóak. Mivel az acetaldehid abszolút és relatív mennyisége drasztikusan csökkent az $\mathrm{Au} / \mathrm{CeO}_{2}$ mintákon $623 \mathrm{~K}$ felett metán és CO képződés nélkül, külön vizsgálatot végeztünk az acetaldehid reakcióira ezeken a katalizátorokon. 2-pentanon és 3-pentén-2-on képződött hidrogénnel, krotonaldehiddel, széndioxiddal és acetonnal együtt. A metán és CO csak 773 K-en jelent meg, 2-3\%-nyi mennyiségben.
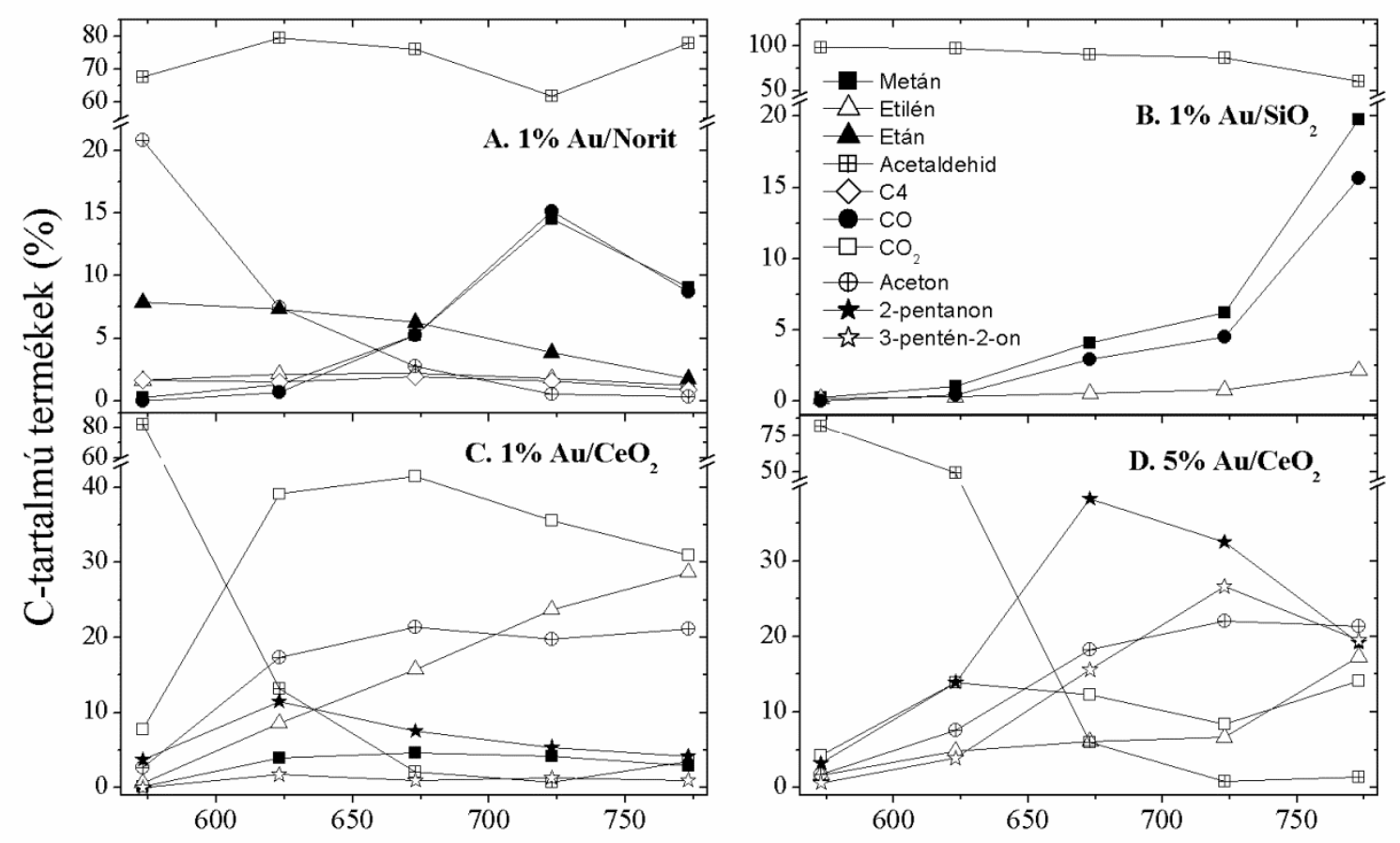

Hõmérséklet (K)

16. ábra $\mathrm{Az}$ etanol bomlása során képzödött termékek összetétele 1\% Au/norit (A), 1\% Au/SiO $(B)$, $1 \% \mathrm{Au} / \mathrm{CeO}_{2}(\mathrm{C})$ és $5 \% \mathrm{Au} / \mathrm{CeO}_{2}$ katalizátorokon a hömérséklet függvényében

$1 \% \mathrm{Au} / \mathrm{CeO}_{2}$ katalizátoron kinetikus méréseket végeztünk alacsony konverzióknál. $\mathrm{Az}$ etanol parciális nyomását változtattuk, a teljes áramlási sebességet $60 \mathrm{ml} / \mathrm{min}$-es értéken tartottuk inert argon gáz hozzáadásával. Ezen körülmények között az etanol reakciója első rendủ kinetikát mutatott. Ezeket a kísérleteket 523 - 583 K közötti hömérséklettartományban hajtottuk végre. Az etanol konverziója 2 és 9\% között változott. Az etanol bomlásának aktiválási energiája az Arrhenius-egyenletből számolva $57 \mathrm{~kJ} / \mathrm{mol}$ és 75,6 kJ/mol a hidrogénképződésre vonatkozóan. Amikor áramlásos rendszerben követtük a bomlást időben 
$\mathrm{Au} / \mathrm{CeO}_{2}$-on $623 \mathrm{~K}$-en, csak kis csökkenést tapasztaltunk a konverzióban és a termék eloszlásban 10 h alatt. 773 K-en azonban a dezaktiválódás sokkal hangsúlyosabb volt.

Az etanolhoz való víz hozzáadása csökkentette az etanol konverzióját az alacsonyabb hőmérséklettartományban az aktív $\mathrm{Au} / \mathrm{CeO}_{2}$ és az $\mathrm{Au} / \mathrm{Al}_{2} \mathrm{O}_{3}$ katalizátoroknál, és a teljes konverziót csak 773 K-en érte el. A termékeloszlásban számottevő változás nem jelent meg, hasonló jelenségeket tapasztaltunk a többi mintáknál is.

\subsubsection{In situ FTIR tanulmány}

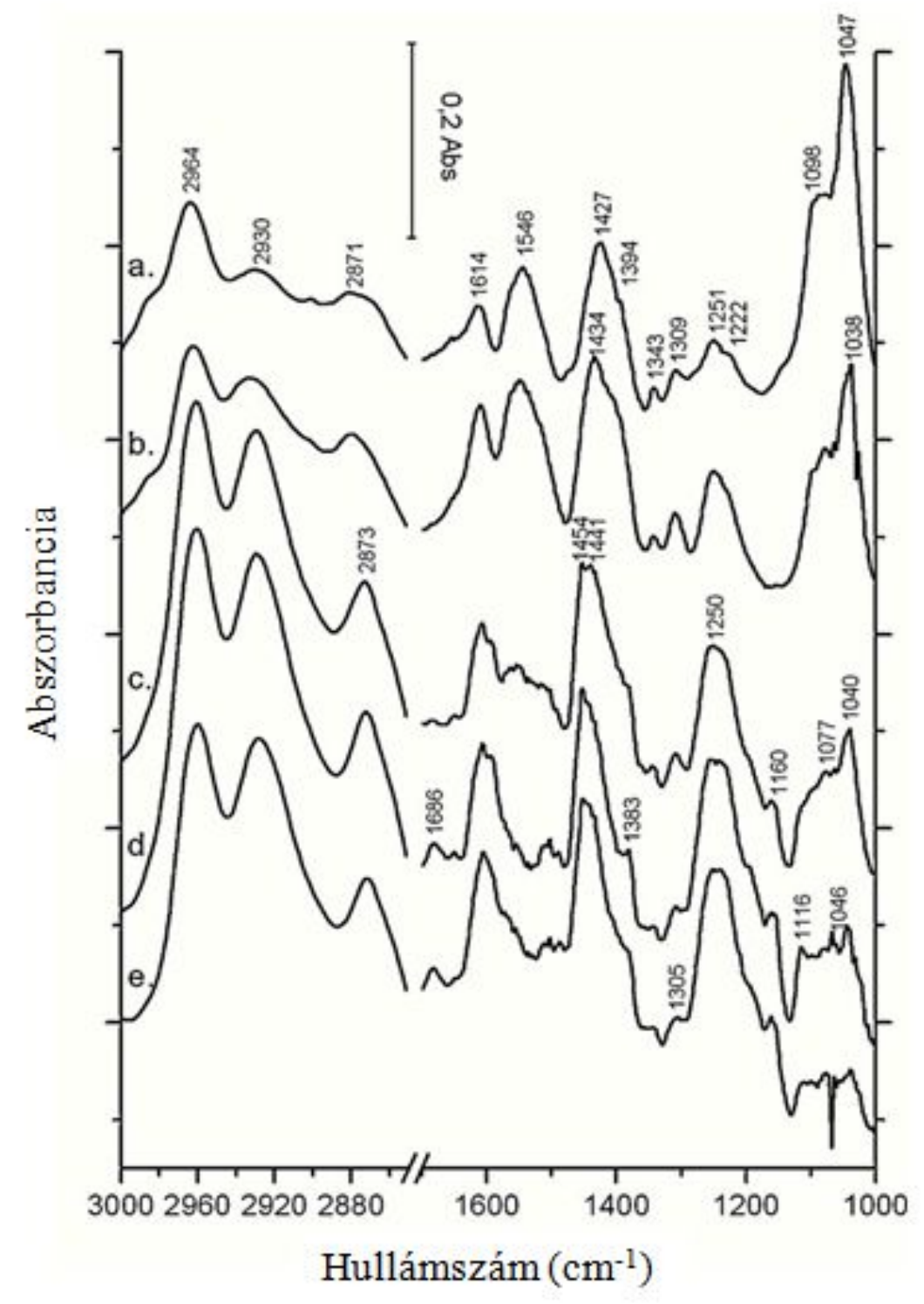

17. ábra $1 \% \mathrm{Au} / \mathrm{CeO}_{2}$-on regisztrált in situ DRIFT spektrum az etanol bomlása során 573-773 K. (a) $573 \mathrm{~K}$, (b) $623 \mathrm{~K}$, (c) $673 \mathrm{~K}$, (d) $723 \mathrm{~K}$ és (e) $773 \mathrm{~K}$-en 
Az etanol $1 \% \mathrm{Au} / \mathrm{CeO}_{2}$-on történő bomlásakor felvett DRIFT spektrumokat a 17. ábrán mutatjuk be különbözö hömérsékleteken. 573-623 K között könnyen detektálható sávok láthatóak a CH-rezgési tartományban 2964, 2930 és $2871 \mathrm{~cm}^{-1}$ hullámszámoknál. Az alacsonyabb frekvencia tartományban intenzív sávok figyelhetők meg 1614, 1546, 1427 , 1394, 1251, 1098 és $1047 \mathrm{~cm}^{-1}$-nél. Amint a hőmérsékletet fokozatosan emeljük 673-773 K-ig új sávok fejlődését figyeltük meg $1686 \mathrm{~cm}^{-1}$-nél. $723 \mathrm{~K}$-en a fő spektrális jellemzők 2961, 2929, 2873, 1686 1610,1594, 1454, 1441, 1383, 1250, 1160, 1077, és $1046 \mathrm{~cm}^{-1}$-nél helyezkednek el. A $\mathrm{CO}_{2}$ rezgési sávja 2361 és $2333 \mathrm{~cm}^{-1}$-nél már megjelent $573 \mathrm{~K}$-en, és erösebbé vált magasabb hömérsékleten.

\subsubsection{A katalizátorok XPS vizsgálata a reakció folyamán}

Annak érdekében, hogy a katalizátor felületén lejátszódó reakciókba jobban beleláthassunk, az etanol bomlását a hordozós arany katalizátorokon követtük egy mini reaktorban, amelyet az XPS rendszerhez kapcsoltuk. Időről időre a mintát leszívattuk és behelyeztük a vákuum kamrába. Az ehhez tartozó XPS spektrumot mutatja a 18. ábra. Amikor a reakciót $673 \mathrm{~K}$ alatt hajtottuk végre $5 \% \mathrm{Au} / \mathrm{CeO}_{2}$-on, akkor nem vagy nagyon kis eltérést tapasztaltunk az Au és a Ce kötési energiáinál. Amint a hőmérsékletet emeltük az $\mathrm{Au}$ 4f 7/2 kötési energia elmozdult 84,1-rö1 84,6 eV-ra $673 \mathrm{~K}$-en és 84,7-re 773-en jelezve az Au részleges oxidációját. A $\mathrm{Ce}^{3+}$ kötési energiájának intenzitása a 885,1 és 900,2 eV-nál erőteljesebbé vált, valószínüsítve a $\mathrm{Ce}^{4+}$ redukcióját a reakció során. Ugyanekkor $673-773 \mathrm{~K}$ között az oxigén 1s jele csökkent és a C 1s jel jelentősen nőtt, mutatva a széntartalmú csoportok bomlását a katalizátorokon, nagy valószínüséggel a $\mathrm{CeO}_{2}$ hordozón. A 2\% $\mathrm{Au} /$ norit kötési energiái lényegében változatlanok maradtak a reakció alatt. Egy új gyenge oxigén 1s jel jelent meg 533,3 eV-nál. Az etanol 2\% Au/ $\mathrm{SiO}_{2}$-on való bomlása eltolódást okozott az arany 4f 7/2 helyzetében 0,2 eV-tal $573 \mathrm{~K}$-en. Magasabb hőmérsékleten nem jelent meg további változás. Ezzel szemben az etanol $573 \mathrm{~K}$-en történő reakciója intenzitásnövekedést okozott a C1s csúcsban 285,1 eV-on, amely tovább növekedett a hőmérséklet emelkedésével. 


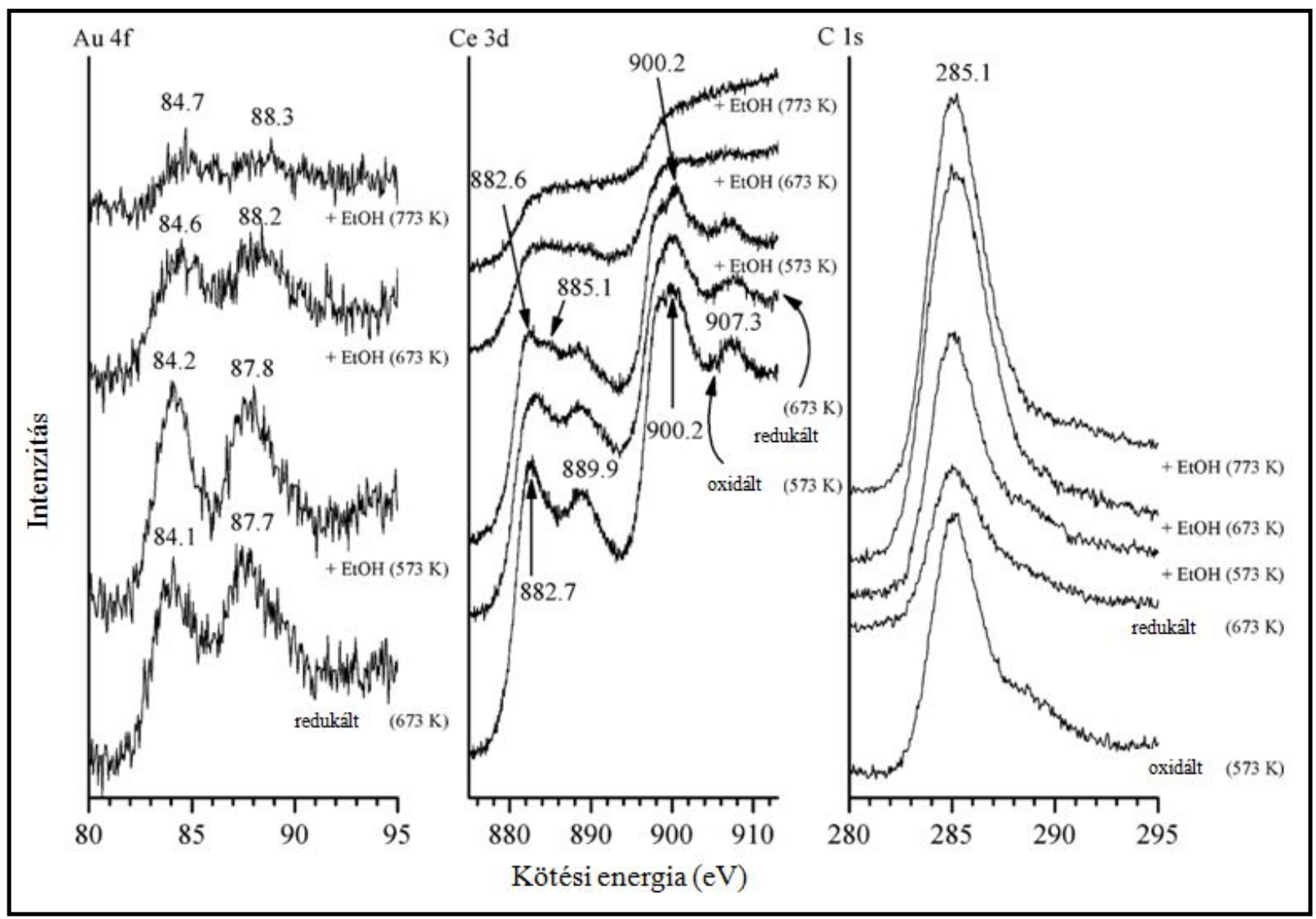

18. ábra 5\% $\mathrm{Au} / \mathrm{CeO}_{2} \mathrm{XPS}$ spektrumai az etanol reakciója után különbözö hömérsékleteken

\subsubsection{TPR mérések}

A katalitikus kísérletek végeztével TPR méréseket hajtottunk végre (19. ábra). A felszíni széntartalmú lerakódások mennyisége és lerakódás fajtája függött a reakcióhőmérséklettől. $\mathrm{Az}$ etanol 1\% Au/ $\mathrm{CeO}_{2}$-on $623 \mathrm{~K}$-en 13 órás reakció után, a felületi szén csak $600 \mathrm{~K}$ fölött reagált a hidrogénnel metán, etilén, etán, propilén és propán képződését eredményezve, $\mathrm{Tp}=705-730 \mathrm{~K}$-es csúccsal (19.A). 2\% $\mathrm{Au} / \mathrm{SiO}_{2}$-on nagy mennyiségü metánt, etánt és etilént találtunk a Tp $=800 \mathrm{~K}$-nél (19.B). A felületi szén reaktivitása sokkal kisebb volt, amikor előzőleg az etanolt $1 \% \mathrm{Au} / \mathrm{CeO}_{2}$-on bontottuk $773 \mathrm{~K}$ en 13 órán keresztül. Ebben az esetben csak metán, etilén és etán keletkezett $700 \mathrm{~K}$ fölött, jól azonosítható csúcsok nélkül. 

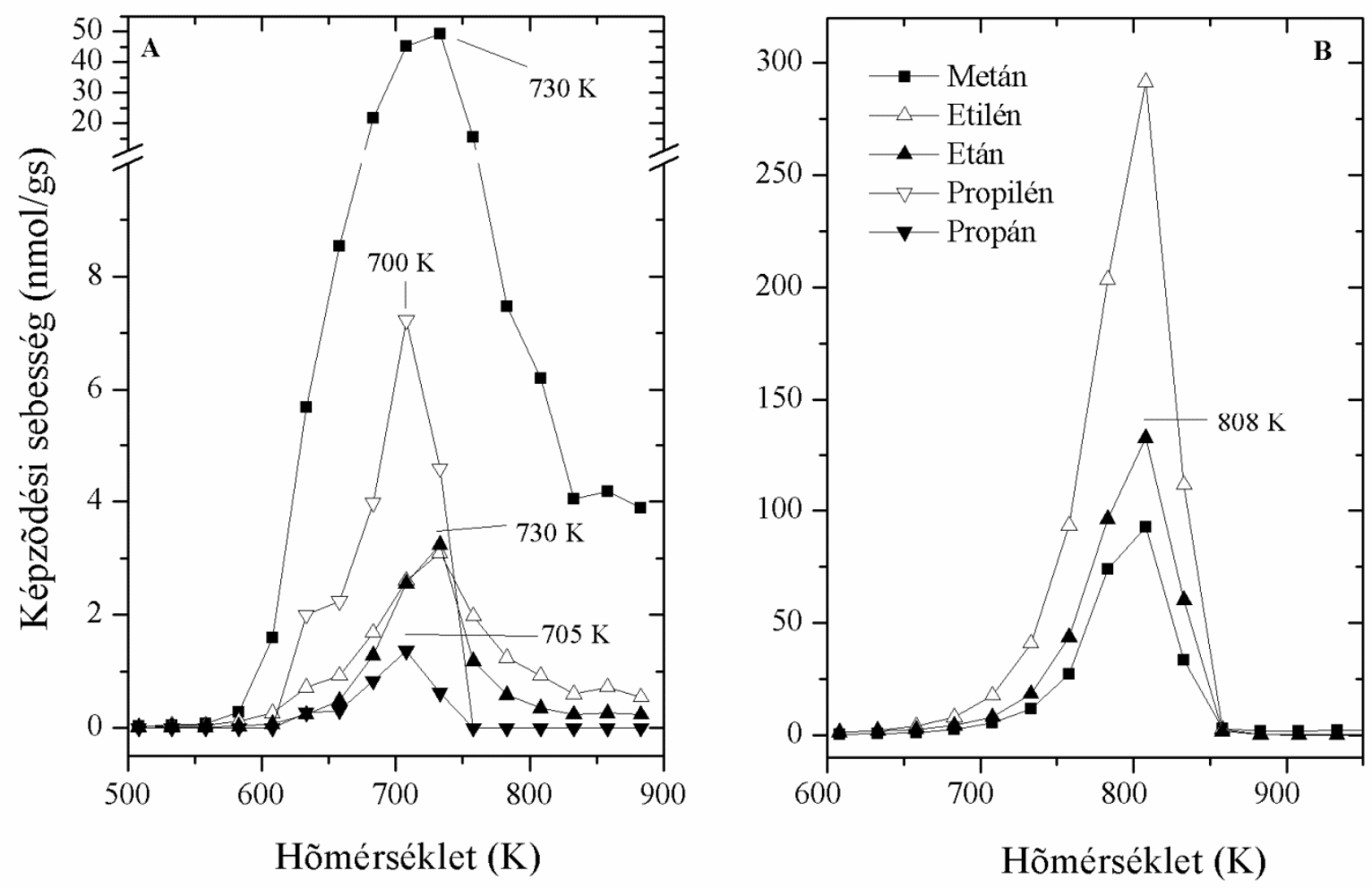

19. ábra $\mathrm{Az}$ etanol $623 \mathrm{~K}$-en történö 13 órás bomlása után mért TPR spektrum $1 \% \mathrm{Au} / \mathrm{CeO}_{2}(\mathrm{~A})$ és $2 \% \mathrm{Au} / \mathrm{SiO}_{2}(\mathrm{~B})$ katalizátorokon

\subsubsection{Eredmények értelmezése}

Míg a metanol kölcsönhatása fém egykristály felületen UHV-ban kiterjedt kutatások témája volt ${ }^{118}$, csak kevés dolgozat érhető el az arany felületekkel kapcsolatban ${ }^{119-123}$. Gong és Mullins ${ }^{122}$ beszámolt arról, hogy az etanol csak gyengén adszorbeálódik és molekulárisan deszorbeálódik tiszta $\mathrm{Au}(111)$ felületen, viszont az általuk kapott eredmény feltételezhetően nem érvényes a hordozott arany nanorészecskék viselkedésére. Mivel az etanol disszociálva adszorbeálódik az oxid vegyületek többségén, ezért nehéz kiküszöbölni a hordozók hatását az etanol és az arany részecskék kölcsönhatását vizsgálva. A szilícium-dioxid és norit minta viszont lehetőséget biztosít, mert mind két hordozón csak gyengén adszorbeálódik az etanol, így a mérések során ezekben az esetekben a hordozók hozzájárulása gyakorlailag elhanyagolható mértékü. Amíg a tiszta szilícium-dioxidról csak a gyengén kötődő etanol deszorpcióját figyeltünk meg, addig az arany tartalmú szilícium-dioxid felületéről hidrogén, acetaldehid, etilén és metán deszorpcióját is tapsztaltuk, ez az eredmény arra enged 
következtetni, hogy az arany részecskéhez erősen kötődődik az adszorbeátum, amely aztán átalakult az infravörös spektroszkópiás vizsgálatokkal kimutatott különböző felületi formákká (13. ábra). Ezek a felületi formák csak magas hőmérsékleten bomlottak különböző termékekké (14. ábra). Hasonló volt a helyzet, amikor aranyat dotáltunk szén-norit felületére. Mivel a termékek sokkal nagyobb mennyisége deszorbeálódott az arany/ $\mathrm{CeO}_{2}$-ról 500-750 K tartományban (14.A ábra), feltételezhetjük, hogy a legtöbb aktivált etanol a $\mathrm{CeO}_{2}$-on tartózkodik. Azonban ezeknek a deszorbeálódó termékeknek kisebb mennyiségét észleltük a tiszta $\mathrm{CeO}_{2}$-nál, amely azt jelzi, hogy az arany/ $\mathrm{CeO}_{2}$ esetében az aranyon aktiválódott etanol egy része átvándorol az aranyról a $\mathrm{CeO}_{2}$-ra. Illetve az etanol adszorpciója az arany/ $\mathrm{CeO}_{2}$ határfelületen is lejátszódhat.

Az arany mintákon megjelenő felületi folyamat alaposabb megismerését teszik lehetővé az FTIR spektroszkópiai mérések. Kiterjedt kutatások témája volt az etanol adszorpciójának IR tanulmányozása a tiszta $\mathrm{CeO}_{2}$ és $\mathrm{CeO}_{2}$ alapú katalizátorokon ${ }^{52,116,117,125-}$ 126.

Habár nem könnyü megkülönböztetni egymástól a molekulárisan és disszociatívan adszorbeált etanolt, a korábbi dolgozatok eredményei (5. táblázat) szerint az $\mathrm{Au} / \mathrm{CeO}_{2}$-on megjelenő fö sávok 2961 és $2867 \mathrm{~cm}^{-1}$-nél egész bizonyosan az aszimmetrikus és szimmetrikus rezgéseket jelölik, míg a 1101 és $1054 \mathrm{~cm}^{-1}$-nél lévő csúcsok az etoxi csoport $v(\mathrm{CO})$ rezgéséhez rendelhetőek (13.A ábra). A molekulárisan adszorbeált etanolra utalnak az $1279 \mathrm{~cm}^{-1}$ és $1387 \mathrm{~cm}^{-1}$-nél látható abszorpciós sávok, amit a $\delta(\mathrm{OH})$ és $v(\delta \mathrm{CH} 3)$ jelenléte jelez. Mivel gyakorlatilag ugyanazt a spektrumot kaptuk a tiszta $\mathrm{CeO}_{2}$-ra, ezért következtethetünk arra, hogy az azonosított sávok föként a $\mathrm{CeO}_{2}$-hoz kötődő adszorbeált etoxihoz rendelhetőek. Az 1550 és $1461 \mathrm{~cm}^{-1}$ hullámszámoknál lévő abszorpciós sávok a felületi acetát komplex $v_{\mathrm{a}}(\mathrm{COO})$ és $v_{\mathrm{s}}(\mathrm{COO})$ rezgéseit jelzik. Az 1620 és $1594 \mathrm{~cm}^{-1}$ sávok, amelyek csak az $\mathrm{Au} / \mathrm{CeO}_{2}$-on voltak kimutathatók 473-773 K között, a krotonaldehid $v(\mathrm{C}=\mathrm{O})$ és $v(\mathrm{C}=\mathrm{C})$ rezgéseihez tartozhatnak amely az acetaldehid reakciójában képződik:

$$
\mathrm{C}_{2} \mathrm{H}_{5} \mathrm{O}_{(\mathrm{a})}=\mathrm{CH}_{3} \mathrm{CHO}_{(\mathrm{a})}+\mathrm{H}_{(\mathrm{a})}
$$

$2 \mathrm{CH}_{3} \mathrm{CHO}=\mathrm{CH}_{3} \mathrm{CH}=\mathrm{CHCHO}+\mathrm{H}_{2} \mathrm{O}$

Érdekes hogy az adszorbeált acetaldehidre jellemző $v(\mathrm{C}=\mathrm{O})$ csoport1690-1698 $\mathrm{cm}^{-1}$ abszorpciós sávjai nem jelentek meg az $\mathrm{Au} / \mathrm{CeO}_{2}$ szobahőmérsékleten felvett spektrumán (13. ábra). Ez azt jelenti, hogy képződését követően azonnal átalakul krotonaldehiddé (17. 
egyenlet). Ezek az adszorbeált vegyületek nagyon stabilak az $\mathrm{Au} / \mathrm{CeO}_{2}$ felületén, mivel az abszorpciós sávjak még a 773 K-en történő szívatás hatására sem tüntek el.

Az arany szerepét az etanol adszorpciójában és felületi reakcióiban világosan mutatják a $\mathrm{Au} / \mathrm{SiO}_{2}$-on kapott spektroszkópiás eredményeink (13.B ábra). A tiszta $\mathrm{SiO}_{2}$-on megfigyelt gyenge abszorpciós sávok drámaian növekedtek az arany jelenlétében. $\mathrm{Az} \mathrm{Au} / \mathrm{SiO}_{2}$ vizsgálata során megjelent rezgési csúcsoknak a helyzete, amely az adszorbeált etoxi részecskéhez rendelhetö, jó egyezést mutat a $\mathrm{Rh} / \mathrm{CeO}_{2}$ esetén kapott eredményekkel ${ }^{116}$.

Az etanol disszociációjának egy másik módját is figyelembe vehetjük, amikor a C-O kötés felszakadásával etil-csoport képződik:

$$
\mathrm{C}_{2} \mathrm{H}_{5} \mathrm{OH}_{(\mathrm{a})}=\mathrm{C}_{2} \mathrm{H}_{5(\mathrm{a})}+\mathrm{OH}_{(\mathrm{a})}
$$

Ennek a szén-hidrogén fragmentnek a $\mathrm{Rh}(111)$-on meghatározott karakterisztikus rezgései 2910-2920, 1420 és 1150-1180 $\mathrm{cm}^{-1}$ hullámszámoknál vannak ${ }^{127,128}$. Mivel ezeknél a hullámszámoknál az arany minták FTIR spektrumán is megjelentek gyenge sávok, nem zárhatjuk ki ennek a disszociációs folyamatnak a megjelenését.

Mint ahogy a metanol bomlásánál is, az arany nanorészecskék katalitikus hatékonysága függ a hordozó természetétől. Az etanol esetében is megállapíthatjuk, hogy az $\mathrm{Au} / \mathrm{Al}_{2} \mathrm{O}_{3}$ esetében, az $\mathrm{Al}_{2} \mathrm{O}_{3}$ dehidratációs tulajdonsága annyira meghatározó, hogy az arany hatása nem tud érvényesülni. Ennek következtében nem képződik $\mathrm{H}_{2}$. Az összes többi arany mintáknál, az etanol dehidrogénezése volt a fó folyamat (16. egyenlet). Ez az a reakció az $\mathrm{Au} / \mathrm{CeO}_{2}$-on játszódott le a legnagyobb sebességgel, ahol az elbomlott etanol hidrogén tartalmának több mint 30\%-a alakult át gázfázisú hidrogénné (15. ábra). A csekély mértékü metanol és $\mathrm{CO}_{2}$ képződés azonban jelezte, hogy a C-C kötés felszakadás szintén végbemegy. Mivel ezt csak korlátozott mértékben figyeltük meg, nem meglepő, hogy az etanolhoz hozzáadott víz csak kissé befolyásolja a termékeloszlást, és jelentősen a hidrogénképződést.

$\mathrm{Az} \mathrm{Au} / \mathrm{CeO}_{2}$ mintán 573-773 K-en végrehajtott in situ IR spektroszkópiai méréseink (17. ábra) különböző részecskék jelenlétét tárták fel a katalizátor felületén, melyek az adszorbeált etanolból alakultak ki fütés hatására (14. ábra): disszociálatlan etanol (1252 és $\left.1383 \mathrm{~cm}^{-1}\right)$, etoxi gyök $\left(2964,2867,1100\right.$ és $\left.1054 \mathrm{~cm}^{-1}\right)$, acetát $\left(1621,1547\right.$ és $1427-1445 \mathrm{~cm}^{-}$ ${ }^{1}$ ) és krotonaldehid (1620 és $1594 \mathrm{~cm}^{-1}$ ). Továbbá CO (1900-1910 cm $\left.\mathrm{cm}^{-1}\right), \mathrm{CO}_{2}$ (2361 és 2333 $\left.\mathrm{cm}^{-1}\right)$ és acetaldehid (1700-1686 $\left.\mathrm{cm}^{-1}\right)$ képződését is detektáltuk, amely összhangban van a magas hőmérsékletü katalitikus reakció termékeloszlásával. 
Egy fontos tulajdonság az $\mathrm{Au} / \mathrm{CeO}_{2}$ magas aktivitásának értelmezésénél az a tény, hogy a tiszta $\mathrm{CeO}_{2}$ ugyancsak katalizálja az etanol bomlását, igaz, hogy csak 673-773 K hőmérsékleteken tapasztaltunk jelentősebb reakciót. Míg 673 K-en az etanol konverziója $\mathrm{CeO}_{2}$-on csupán $15 \%$ körül volt, addig $1 \% \mathrm{Au} / \mathrm{CeO}_{2}$-on elérte a $80 \%$-ot. Ezek az adatok egyértelmüen utalnak az arany nanorészecske és a $\mathrm{CeO}_{2}$ hordozó közötti kommunikációs hatásra. Feltételezhetjük, hogy az $\mathrm{Au} / \mathrm{CeO}_{2}$ nagyon aktív helyeket tartalmaz, amely feltételezhetően egy határfelület az arany és a részlegesen redukált $\mathrm{CeO}_{\mathrm{x}}$ között, ahol elektromos kölcsönhatás jöhet létre az arany és az n-típusú $\mathrm{CeO}_{2}$ félvezető között, hasonló módon ahhoz, amelyet először a Ni és n-típusú $\mathrm{TiO}_{2}$ között fedeztek fel ${ }^{77,78}$. Figyelembe véve a vizsgált szilárd felületeken az etanol adszorpciója és reakciója során azonnal kialakuló etoxi gyököt, nagyon valószínünek tűnik, hogy az etanol bomlásában a sebesség meghatározó lépés valamelyik C-H kötés felszakadása az etoxi gyökökben:

$$
\mathrm{C}_{2} \mathrm{H}_{5} \mathrm{O}_{(\mathrm{a})}=\mathrm{C}_{2} \mathrm{H}_{4} \mathrm{O}_{(\mathrm{a})}+\mathrm{H}_{(\mathrm{a})}
$$

A termékeloszlásban szintén megnyilvánult az $\mathrm{Au} / \mathrm{CeO}_{2}$ jellegzetes katalitikus viselkedése. Az acetaldehid - amely a dehidrogénezési reakció fő termékének bomlása metánná és CO-dá csak nagyon kis mértékben játszódik le:

$\mathrm{C}_{2} \mathrm{H}_{4} \mathrm{O}_{(\mathrm{a})}=\mathrm{CH}_{4}+\mathrm{CO}$

E helyett inkább különböző szénhidrogénekké alakul át és oligomerizálódik 2pentanonná és 3-pentén-2-onná. Utóbbi vegyületeket kis mennyiségben a tiszta $\mathrm{CeO}_{2}$ is alkalmazásakkor is kimutattuk, mennyiségük jelentősen emelkedett az aranytartalom növekedésével. Képződésüket az eddigi dolgozatok nem közölték a cérium-hordozós átmeneti fémeken ${ }^{52,116,117,124-126,129,130}$, amelyek a 20. egyenlet szerint hatékonyan katalizálják az acetaldehid bomlását. Hangsúlyozni kell azonban, hogy ezeket a vegyületeket csak a cérium alapú kakatizátoroknál figyeltük meg. Tájékozódó kísérletek bizonyították, hogy az acetaldehid $\mathrm{Au} / \mathrm{CeO}_{2}$-on lejátszódó reakciójában képződött a 2-pentanon és 3-pentén-2-on $623 \mathrm{~K}$ felett. További kísérletek szükségesek, hogy kiderítsük az $\mathrm{Au} / \mathrm{CeO}_{2}$ szerepét az acetaldehid reakciójában.

Mivel az etanol elsődleges reakcióútja a dehidrogéneződés, ezért a CO-t és metánt eredményező C-C kötés felszakadása csak korlátozott mértékben zajlik le, nem meglepő, hogy az etanohoz adott víz csak csekély hatással van a termékeloszlásra. 


\section{Mérési eredmények bemutatása és értelmezése}

\subsubsection{Föbb konklúziók}

(i) A $673 \mathrm{~K}$-en redukált hordozós arany minták XPS jellemzése feltárta $\mathrm{az} \mathrm{Au}^{3+}, \mathrm{Au}^{1+}$ és $\mathrm{Au}^{0}$ egyidejű jelenlétét.

(ii) A tiszta és $\mathrm{Au}$-tartalmú $\mathrm{SiO}_{2}$-on végrehajtott FTIR és TPD vizsgálatok kimutatták, hogy 300 K-en etoxi gyök képződik az Au részecskéken, amely 400 K-en különböző vegyületekké bomlik el, amely $400 \mathrm{~K}$ fölött föként acetaldehidre, hidrogénre, etilénre és metánre bomlik tovább.

(iii) A különböző hordozókra rávitt arany nanorészecskéről bebizonyítottuk, hogy aktív katalizátorai az etanol dehidrogenézésének. A hidrogén képződés és a termékeloszlás érzékenyen függ a hordozó természetétől. A legnagyobb mértékü hidrogén fejlődést az $\mathrm{Au} / \mathrm{CeO}_{2}$-on tapasztaltuk. $623 \mathrm{~K}$-en 10 órás reakcióban az $\mathrm{Au} / \mathrm{CeO}_{2}$ katalizátor nem deaktiválódott.

(iv) $\mathrm{Az}$ etanol $\mathrm{Au} / \mathrm{CeO}_{2}$-on lejátszódó dehidrogénezése során képződött acetaldehid számos, C5 oxo vegyületet is tartalmazó vegyületetté alakult át. 


\subsubsection{Dimetil-éter vizsgálata}

\subsubsection{Infravörös spektroszkópiás mérések}

A 20.A ábrán az adszorbeáltatott $D M E$ IR spektrumát mutattuk be $1 \% \mathrm{Au} / \mathrm{CeO}_{2}$-on $\left(T_{R}=673 \mathrm{~K}\right) 300 \mathrm{~K}$-en és azt követően különböző hőmérsékletekre felfütve folyamatos szívatás alatt.

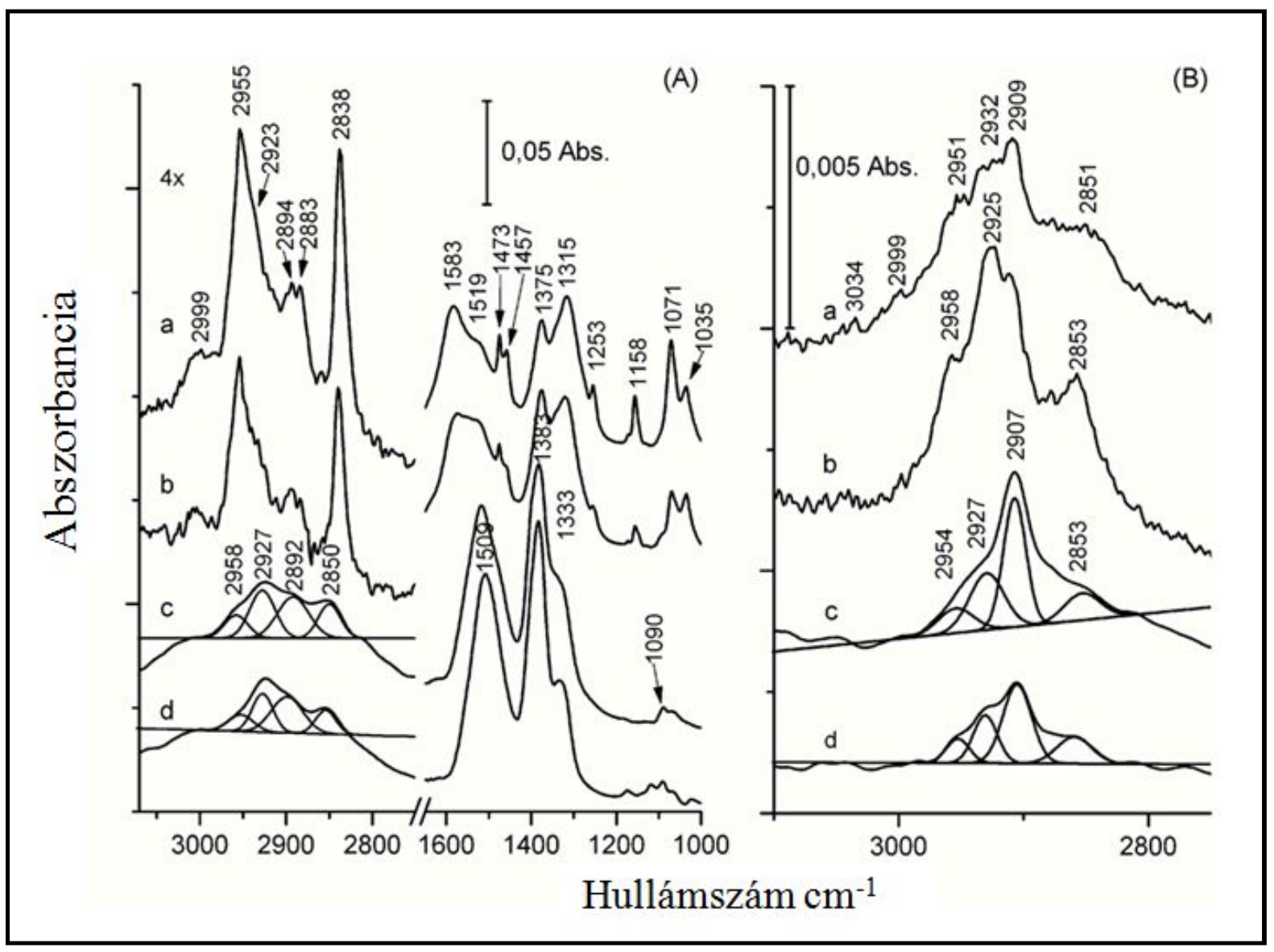

20. ábra $A$ DME $300 \mathrm{~K}$-en történö adszorpcióját követö FTIR spektrumok $1 \% \mathrm{Au} / \mathrm{CeO}_{2}$-on $(\mathrm{A})$ és $1 \%$ $\mathrm{Au}_{\mathrm{Al}} \mathrm{O}_{3}$-on (B) és különbözö hömérsékletekre felfütve folyamatos szivatás közben. a, $300 \mathrm{~K} ; \mathrm{b}, 373$ $K ; c, 423 \mathrm{~K} ; d, 473 \mathrm{~K}$

300 K-en intenzív abszorpciós sávok figyelhetőek meg 2955, 2894, 2883 és $2838 \mathrm{~cm}^{-1}$-nél és kis intenzitású sávok vagy jelentek meg 2999 és 2923 cm-1-nél a C-H rezgési tartományban. Az alacsony frekvencia tartományában a következő abszorpciós sávokat azonosítottunk 1583, 1519, 1473, 1457, 1375, 1315, 1253, 1158, 1071 és $1035 \mathrm{~cm}^{-1}$-nél. A minta felfütése a sávok intenzitásának csökkenését okozta. Jelentős különbség, hogy az adszorbeált felületi formák 
stabilabbak voltak, mint az $\mathrm{Au} / \mathrm{CeO}_{2}$ esetében. Hasonló spektrális jellemzöket tapasztaltunk az $\mathrm{Au} / \mathrm{Al}_{2} \mathrm{O}_{3}$ esetében nagyon kis eltéréssel a sávok helyzetében (20.B ábra).

$\mathrm{Az} \mathrm{Au} / \mathrm{SiO}_{2}$-nál kapott eredmények külön említést érdemelnek. Ezeknek a mintáknak az előnye, hogy a DME csak gyengén adszorbeálódik és nem disszociál a szilika felületén, ezért lehetséges az, hogy a magasabb hőmérsékleten megjelenő rezgési sávok az Au jelenlétéhez kapcsolhatóak. Annak érdekében, hogy megszüntessük a DME gyenge adszorpciójából eredő sávokat az adszorbeált réteget 473 K-re fütöttük folyamatos szívatás alatt. A TPD kísérletek azt mutatták (5.2.3.2.), hogy ez a kezelés elegendő a DME deszorpciójához. Ezt igazolja, hogy a tiszta $\mathrm{SiO}_{2}$ IR spektrumában nem található detektálható spektrális tulajdonság egy ilyen előkezelés után. 5\% Au jelenlétében abszorpciós sávok jelennek meg 2958, 2925, 2912 és $2859 \mathrm{~cm}^{-1}$-nél $373 \mathrm{~K}$-en, amik a minta szívatása után magasabb hőmérsékleten gyengülnek. Mindazonáltal a legtöbb még azonosítható 473-573 Ken is. Az 6. táblázatban soroltuk fel a jellegzetes rezgéseket a DME-re és annak lehetséges disszociációs termékeire vonatkozóan különböző szilárd anyagokon.

6. táblázat A gáznemü és adszorbeálódott dimetil-éter és metanol jellegzetes abszorpciós sávjai különbözö felületeken

\begin{tabular}{|c|c|c|c|c|c|c|c|c|}
\hline $\begin{array}{l}\text { Jellemző } \\
\text { rezgések }\end{array}$ & $\underset{131,132}{\operatorname{DME}}(\mathrm{g})$ & $\begin{array}{c}\mathrm{DME}(\mathbf{a}) \\
\mathrm{Al}_{2} \mathrm{O}_{3} \\
150 \mathrm{~K}- \\
\text { en }^{132}\end{array}$ & $\begin{array}{c}\mathrm{CH}_{3} \mathrm{O}(\mathbf{a}) \\
\mathrm{Al}_{2} \mathrm{O}_{3} \\
150 \mathrm{~K}- \\
\text { en }^{132}\end{array}$ & $\begin{array}{c}\mathrm{CH}_{3} \mathrm{O}(\mathbf{a}) \\
\mathrm{CeO}_{2} \\
523 \mathrm{~K}- \\
\text { en }^{95}\end{array}$ & $\begin{array}{c}\text { DME(a) } \\
\mathrm{CeO}_{2} \\
300 \mathrm{~K}- \\
\text { en }^{69}\end{array}$ & $\begin{array}{c}\mathrm{CH}_{3} \mathrm{O}(\mathrm{a}) \\
\mathrm{Rh} / \mathrm{CeO}_{2} \\
300 \mathrm{~K}^{-} \\
\text {en }^{69}\end{array}$ & $\begin{array}{c}\text { DME(a) } \\
\text { Au/CeO } \\
\text { 300 K-en } \\
\text { (jelen } \\
\text { tanulmány) }\end{array}$ & $\begin{array}{c}\text { DME(a) } \\
\mathrm{Au} / \mathrm{SiO}_{2} \\
373 \mathrm{~K}-\mathrm{en} \\
\text { (jelen } \\
\text { tanulmány) }\end{array}$ \\
\hline \multirow[t]{2}{*}{$v_{\mathrm{a}}\left(\mathrm{CH}_{3}\right)$} & 2996 & 2984 & 2960 & 2911 & 2953 & 2948 & 2955 & 2958 \\
\hline & 2925 & 2922 & & & & & & 2925 \\
\hline$v_{\mathrm{s}}\left(\mathrm{CH}_{3}\right)$ & 2817 & 2821 & 2849 & 2803 & 2841 & 2838 & 2838 & 2912 \\
\hline $2 \delta\left(\mathrm{CH}_{3}\right)$ & 2887 & 2890 & & 2883 & 2884 & & 2889 & 2859 \\
\hline \multirow[t]{2}{*}{$\delta\left(\mathrm{CH}_{3}\right)$} & 1470 & 1477 & 1475 & 1434 & 1436 & 1463 & 1473 & \\
\hline & 1456 & 1459 & 1420 & & & & 1457 & \\
\hline \multirow[t]{2}{*}{$\gamma\left(\mathrm{CH}_{3}\right)$} & 1244 & 1252 & 1081 & & 1229 & & 1253 & \\
\hline & 1179 & 1116 & & & 1159 & 1190 & 1158 & \\
\hline$v_{\text {as }}(\mathrm{CO})$ & 1102 & 1092 & 1055 & 1108 & 1066 & 1095 & 1071 & \\
\hline
\end{tabular}




\subsubsection{Hömérséklet programozott deszorpció}

A TPD spektrumai a különböző termékekre vonatkozóan az Au katalizátorokon DME $300 \mathrm{~K}$-en történő adszorpciója után a 21. ábrán kerültek bemutatásra. $1 \% \mathrm{Au} / \mathrm{CeO}_{2}$-on a DME deszorpciója $300 \mathrm{~K}$ körül gyengén elkezdődött és $370 \mathrm{~K}$ körül érte el a maximum értéket. 560-580 K között $\mathrm{H}_{2}$-t és $\mathrm{CH}_{4}$-t detektáltunk. Nagyon kis mennyiségben etán deszorpciója is megfigyelhető volt 480 és $560 \mathrm{~K}$ között (21.A ábra). Nagyon hasonló ehhez a tiszta $\mathrm{CeO}_{2}$ esetében detektált TPD spektrum. A DME deszorpciója 1\% $\mathrm{Au} / \mathrm{Al}_{2} \mathrm{O}_{3}$-on 370 és $510 \mathrm{~K}$ között történt meg. Ezen kívül a metanol deszorpcióját $(\mathrm{Tp}=510 \mathrm{~K})$, valamint $\mathrm{H}_{2}, \mathrm{CO}$ és $\mathrm{CH}_{4}$ ugyanazon csúcshőmérséklettel, $\mathrm{Tp}=650 \mathrm{~K}$-en detektáltuk. Ha dimetil-étert adszorbeáltattunk $1 \% \mathrm{Au} / \mathrm{CeO}_{2}-\mathrm{Al}_{2} \mathrm{O}_{3}$ katalizátoron (együttes impregnálással előállított), DME $(380-500 \mathrm{~K}), \mathrm{CO}$ és $\mathrm{H}_{2}(590 \mathrm{~K})$ deszorpcióját regisztráltuk. 2\% $\mathrm{Au} / \mathrm{SiO}_{2}$ esetében csak a DME deszorpciója volt megfigyelhető $(\mathrm{Tp}=350 \mathrm{~K})$.

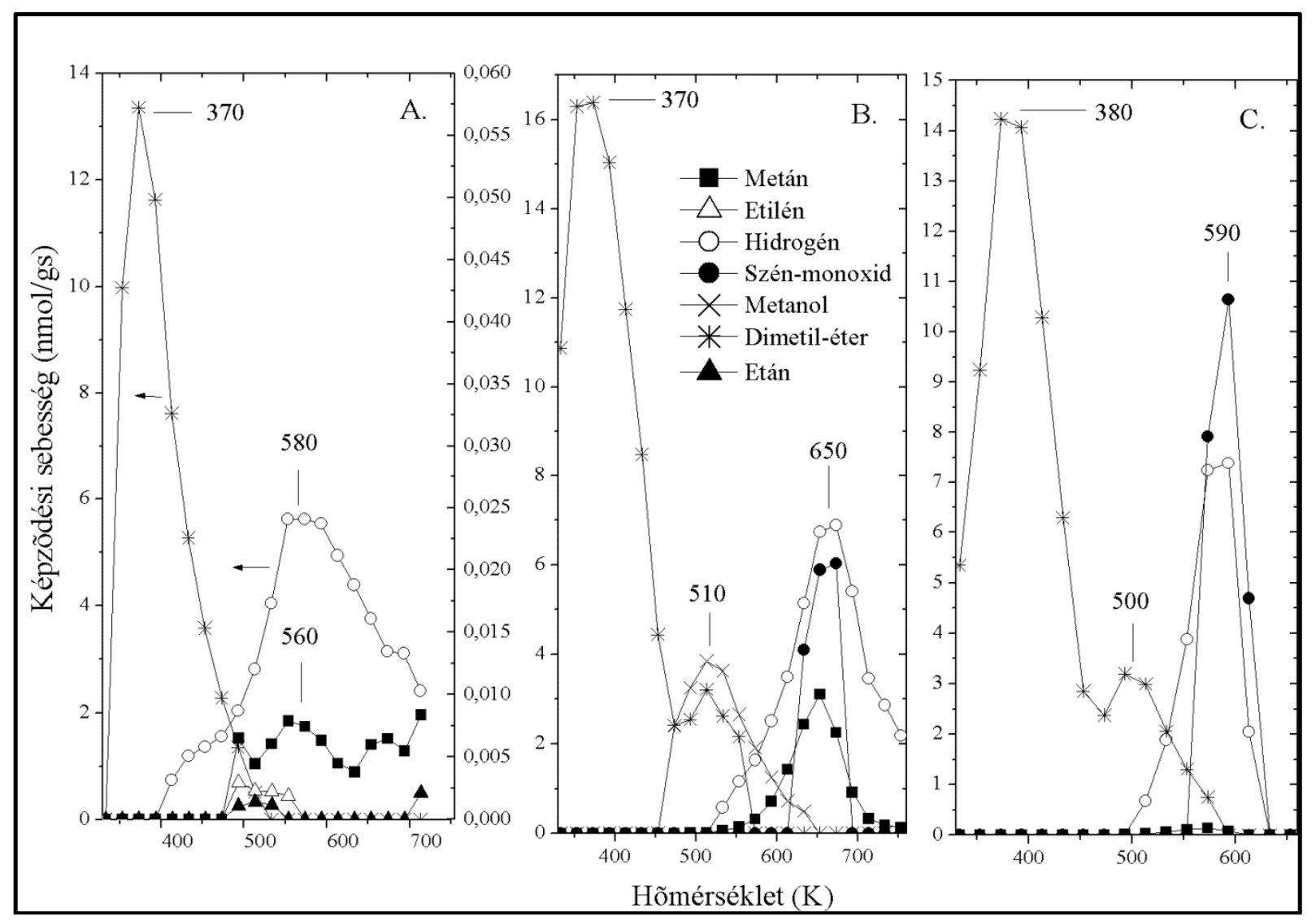

21. ábra $A$ DME $300 \mathrm{~K}$-en történö adszorpcióját követö TPD spektrumok $1 \% \mathrm{Au} / \mathrm{CeO}_{2}(\mathrm{~A}), 1 \%$ $\mathrm{Au}_{\mathrm{Al}} \mathrm{O}_{3}(\mathrm{~B})$ és $1 \% \mathrm{Au} / \mathrm{CeO}_{2}+\mathrm{Al}_{2} \mathrm{O}_{3}$ (együttes impregnálás) (C) katalizátorokon 


\subsubsection{Katalitikus vizsgálatok}

A $\mathrm{SiO}_{2}$-on, $\mathrm{MgO}$-on és szén noriton impregnált $\mathrm{Au}$ nanorészecskék nagyon gyenge katalitikus aktivitást mutattak a DME bomlásában. Ezeken a katalizátorokon 773 K-en a konverzió kevesebb volt, mint 2-3\%. Némileg magasabb aktivitást mértünk az 1\% $\mathrm{Au} / \mathrm{TiO}_{2}$ mintát vizsgálva, ahol $573 \mathrm{~K}$-en már észlelhető volt a bomlás és a konverzió elérte a 30\%-ot $873 \mathrm{~K}$-en. A detektált termékek: $\mathrm{CH}_{4}, \mathrm{CH}_{3} \mathrm{OH}, \mathrm{H}_{2}, \mathrm{CO}$ és egy kevés $\mathrm{C}_{2} \mathrm{H}_{6}$. Viszont a hidrogénképződés hozama kevesebb volt, mint 10\% 773K-en. $\mathrm{Az} 1 \% \mathrm{Au} / \mathrm{CeO}_{2}$ katalizátor hasonló katalitikus teljesítményt mutatott, mint az $\mathrm{Au} / \mathrm{TiO}_{2}$ azzal a különbséggel, hogy a $\mathrm{H}_{2}$ tartalom sokkal magasabb volt, 50-60\% (22.A ábra).

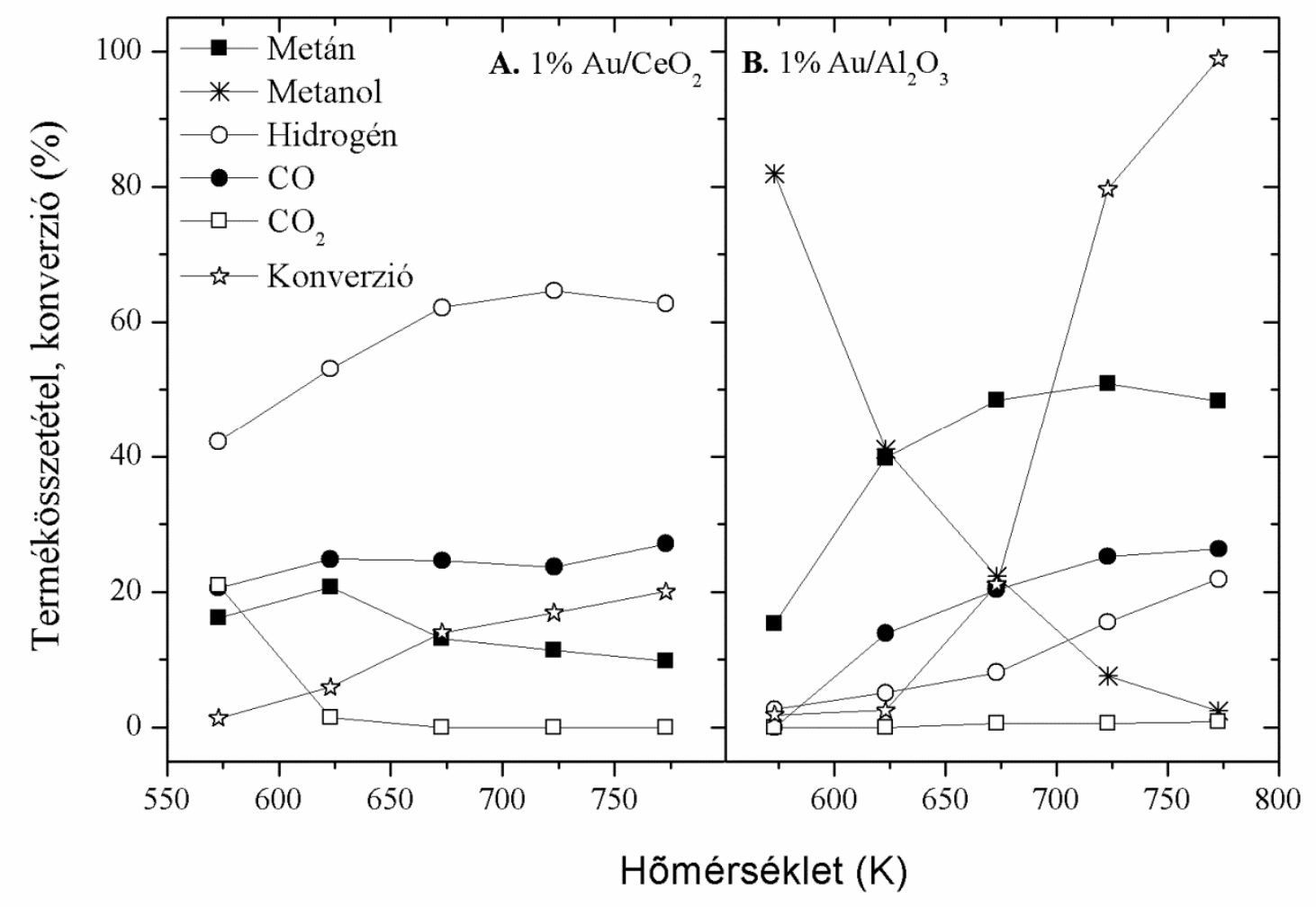

22. ábra A DME konverziója és a bomlása során képzödött termékek százalékos eloszlása $1 \% \mathrm{Au} / \mathrm{CeO}_{2}$-on (A) illetve 1\% $\mathrm{Au} / \mathrm{Al}_{2} \mathrm{O}_{3}$-on (B) különbözö hömérsékleteken

Viszont az alacsony konverzió (20\%) következtében a $\mathrm{H}_{2}$ yield alacsonyabb volt, mint $15 \%$ $773 \mathrm{~K}$-en. $\mathrm{Az} \mathrm{Au} / \mathrm{CeO}_{2}$ egy hátrányos tulajdonságát figyeltük meg ezen mérések során, miszerint a DME bomlási reakciójában az eddigi vizsgálatoktól eltérően igen gyorsan 
dezaktiválódott $773 \mathrm{~K}$-en. Az Au tartalom 5\%-ra növelése csak gyenge emelkedést okozott a DME konverziójában, ami így elérte a $25 \%$-ot $773 \mathrm{~K}$-en. A $673 \mathrm{~K}$-en redukált tiszta $\mathrm{CeO}_{2}$ nagyon kicsi aktivitást mutatott, még $773 \mathrm{~K}$-en is kevesebb, mint $1 \%$ konverziót mértünk. Alapvetően más volt a helyzet az $\mathrm{Al}_{2} \mathrm{O}_{3}$ hordozós katalizátorokon. $1 \% \mathrm{Au} / \mathrm{Al}_{2} \mathrm{O}_{3}$-on a $\mathrm{DME}$ konverziója 723 K-en $80 \%$ körüli volt és 773 K-en elérte a teljes bomlást, de a hidrogénképződés alacsony szinten maradt az egész hőmérséklettartományban (22. B ábra). Alacsonyabb hömérsékleten metanol volt a fö termék. Míg $673 \mathrm{~K}$ körül $\mathrm{CH}_{4}, \mathrm{CO}, \mathrm{H}_{2}$ képződést is határoztunk meg és a $\mathrm{CH}_{3} \mathrm{OH}$ mennyiségben csökkenő változást tapasztaltunk. A $\mathrm{H}_{2}$ hozama ebben az esetben sem haladta meg a 20\%-ot 723-773 K között. $\mathrm{Az} \mathrm{Au} / \mathrm{Al}_{2} \mathrm{O}_{3}$ nem mutatott dezaktiválódást $773 \mathrm{~K}$-en 10 óra elteltével sem. A tiszta $\mathrm{Al}_{2} \mathrm{O}_{3}$ is relatíve magas aktivitást mutatott a DME bomlásában. A konverzió 68\% volt 723 K-en és 773 K-en $88 \%$-ra növekedett. A termékek eloszlása gyakorlatilag hasonló volt az $\mathrm{Au} / \mathrm{Al}_{2} \mathrm{O}_{3}$-on mértekkel, de a hidrogén képződése kevesebb volt.

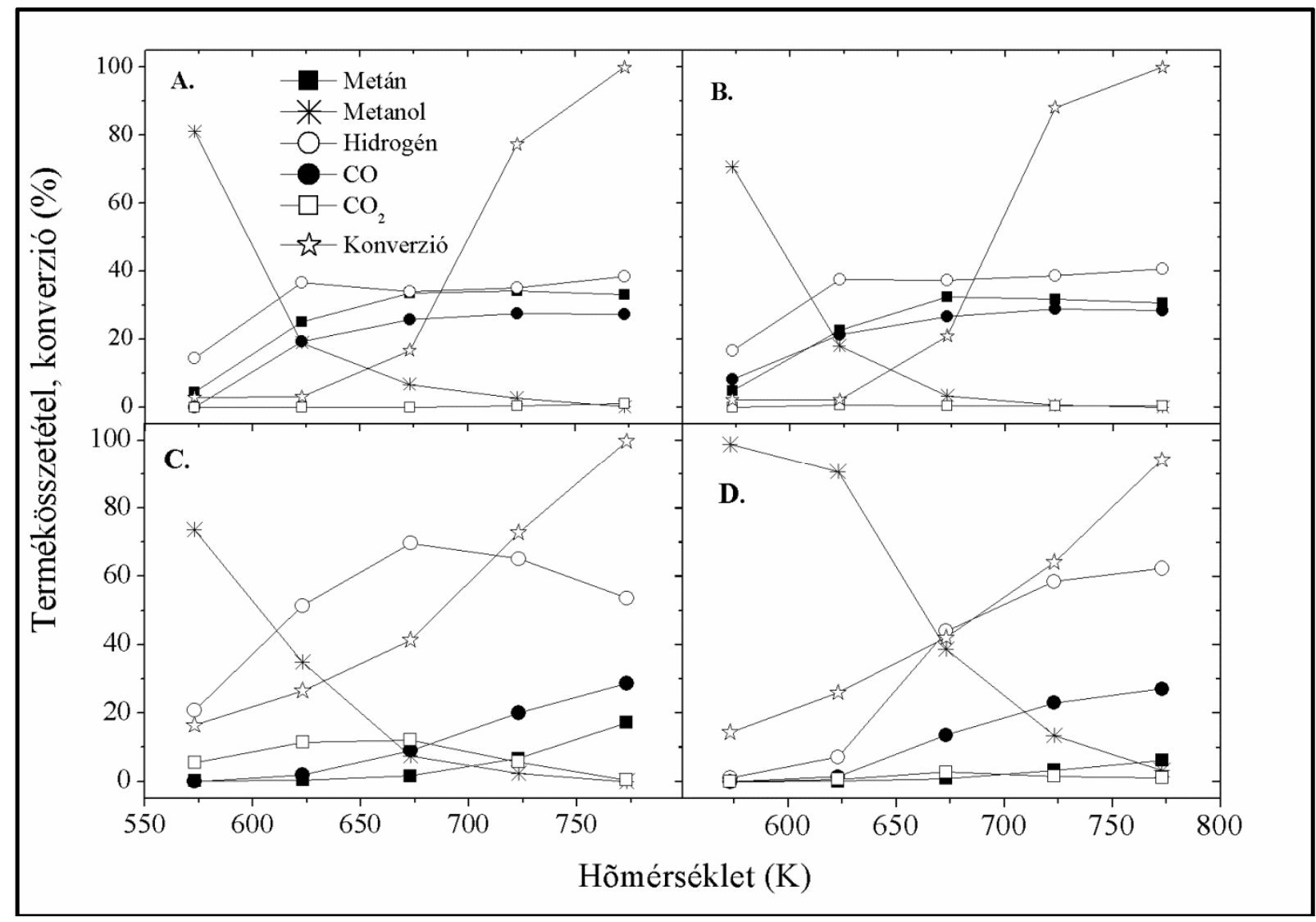

23. ábra $\mathrm{A}$ DME konverziója és a képzödött termékek összetétel a bomlás $1 \% \mathrm{Au} / \mathrm{CeO}_{2}+\mathrm{Al}_{2} \mathrm{O}_{3}$ (kevert) (A), és $1 \% \mathrm{Au} / \mathrm{CeO}_{2}+\mathrm{Al}_{2} \mathrm{O}_{3}$ (együttes lecsapás) (B) katalizátorokon illetve a reformálás során $1 \% \mathrm{Au} / \mathrm{CeO}_{2}+\mathrm{Al}_{2} \mathrm{O}_{3}$-on (kevert) (C), és $1 \% \mathrm{Au} / \mathrm{CeO}_{2}+\mathrm{Al}_{2} \mathrm{O}_{3}$-on (együttes lecsapás) (D) a hömérséklet függvényében 


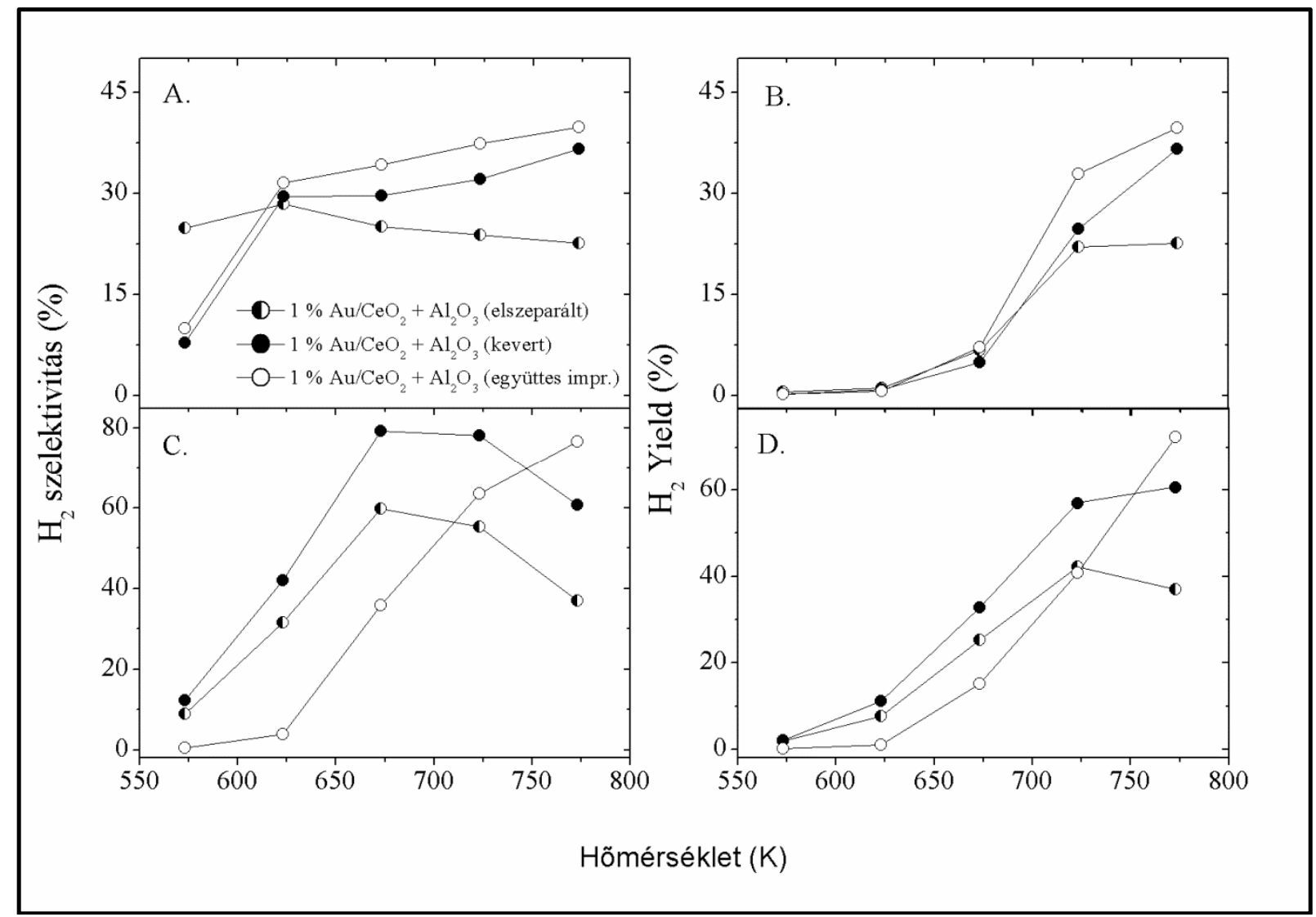

24. ábra $A$ hidrogén szelektivitás és Yield a DME bomlása (A és $B)$ és reformálása ( $C$ és $D)$ során a hömérséklet függvényében az $1 \% \mathrm{Au} / \mathrm{CeO}_{2}+\mathrm{Al}_{2} \mathrm{O}_{3}$ tartalmú vegyes oxid katalizátorokon különbözö fizikai megvalósitásban (a két oxid el van szeparálva kvarcgyapottal, mechanikusan van össze keverve illetve együttes impregnálással elöállítva)

Figyelembe véve a kapott eredményeket a különböző katalizátorokon, végeztünk egy kísérletet az Au hordozós alumínium-oxid és cérium-dioxid mintákon előnyös katalitikus tulajdonságaiknak a kombinálásával. $\mathrm{Ha} 1 \% \mathrm{Au} / \mathrm{CeO}_{2}$-ot és $\mathrm{Al}_{2} \mathrm{O}_{3}$-ot kettős katalizátorágyban alkalmaztuk, a DME bomlás mértéke $723 \mathrm{~K}$-en 90\%, $773 \mathrm{~K}$-en 100\% volt. A $\mathrm{H}_{2}$ szelektivitás 22 és $26 \%$ között, a yield értéke $23 \%$ volt $773 \mathrm{~K}$-en. $\mathrm{Ha}$ az $1 \% \mathrm{Au} / \mathrm{CeO}_{2}$-ot mechanikusan kevertük össze az alumínium-oxiddal a $\mathrm{H}_{2}$ szelektivitás $600 \mathrm{~K}$ körül 30-35\% közé esett és a yield $\mathrm{H}_{2} 37 \%$ volt $773 \mathrm{~K}$-en. Magasabb $\mathrm{H}_{2}$ képződés értéket kaptunk, ha az előállításnál az aranyat $\mathrm{Al}_{2} \mathrm{O}_{3}-\mathrm{CeO}_{2}$ vegyes oxidra impregnáltuk. $\mathrm{A} \mathrm{H}_{2}$ szelektivitás $35-40 \%$ volt, a $\mathrm{H}_{2}$ hozam meghaladta a 40\%-os értéket $773 \mathrm{~K}$-en. A termékeloszlást a 23.A és 23.B ábrákon mutattuk be, míg a szelektivitás és $\mathrm{H}_{2}$ hozam értékeket a 24.A és 24.B ábrákon. 
Víz hozzáadása a DME-hez $\left(\mathrm{H}_{2} \mathrm{O} / \mathrm{DME}=1\right)$ drámai hatást gyakorolt a termék

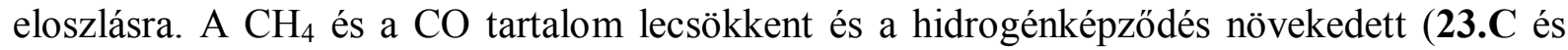
23.D ábrák). Így a $\mathrm{H}_{2}$ szelektivitás majdnem $80 \%$ volt, míg a $\mathrm{H}_{2}$ yield megközelítette a $73 \%$ os értéket (24.C és 24.D ábrák). Időben követve a reakciót $773 \mathrm{~K}$-en 10 óra elteltével sem tapasztaltunk dezaktiválódást. $\mathrm{Ha}$ a $\mathrm{H}_{2} \mathrm{O} / \mathrm{DME}$ arányt háromra növeltük, csak egy kismértékü fokozódást tapasztaltunk a $\mathrm{H}_{2}$ képződésben.

$\mathrm{Az}$ etanol ${ }^{133}$ és a $\mathrm{DME}^{24} \mathrm{Mo}_{2} \mathrm{C} /$ norit katalizátorokon korábban végzett bomlási és reformálási tanulmányainkban azt találtuk, hogy a kálium jelenléte markánsan elősegítette a hidrogénképződést. Hasonlóan hajtottunk végre kísérleteket jelen esetben is. Az elvárásainknak megfelelően azt tapasztaltuk, hogy 1\% K-ot adva az $1 \% \mathrm{Au} / \mathrm{CeO}_{2}-\mathrm{Al}_{2} \mathrm{O}_{3}$ katalizátorhoz pozitív hatást gyakorolt a hidrogénképződésre a DME reformálásában. Ebben az esetben ez eddigi eredményekhez képest még magasabb $\mathrm{H}_{2}$ hozamot mértünk 773 K-en (86-87\%). A 25. ábrán jól látható, hogy ez az érték változatlan maradt időben, 10 órát követve a reakciót.

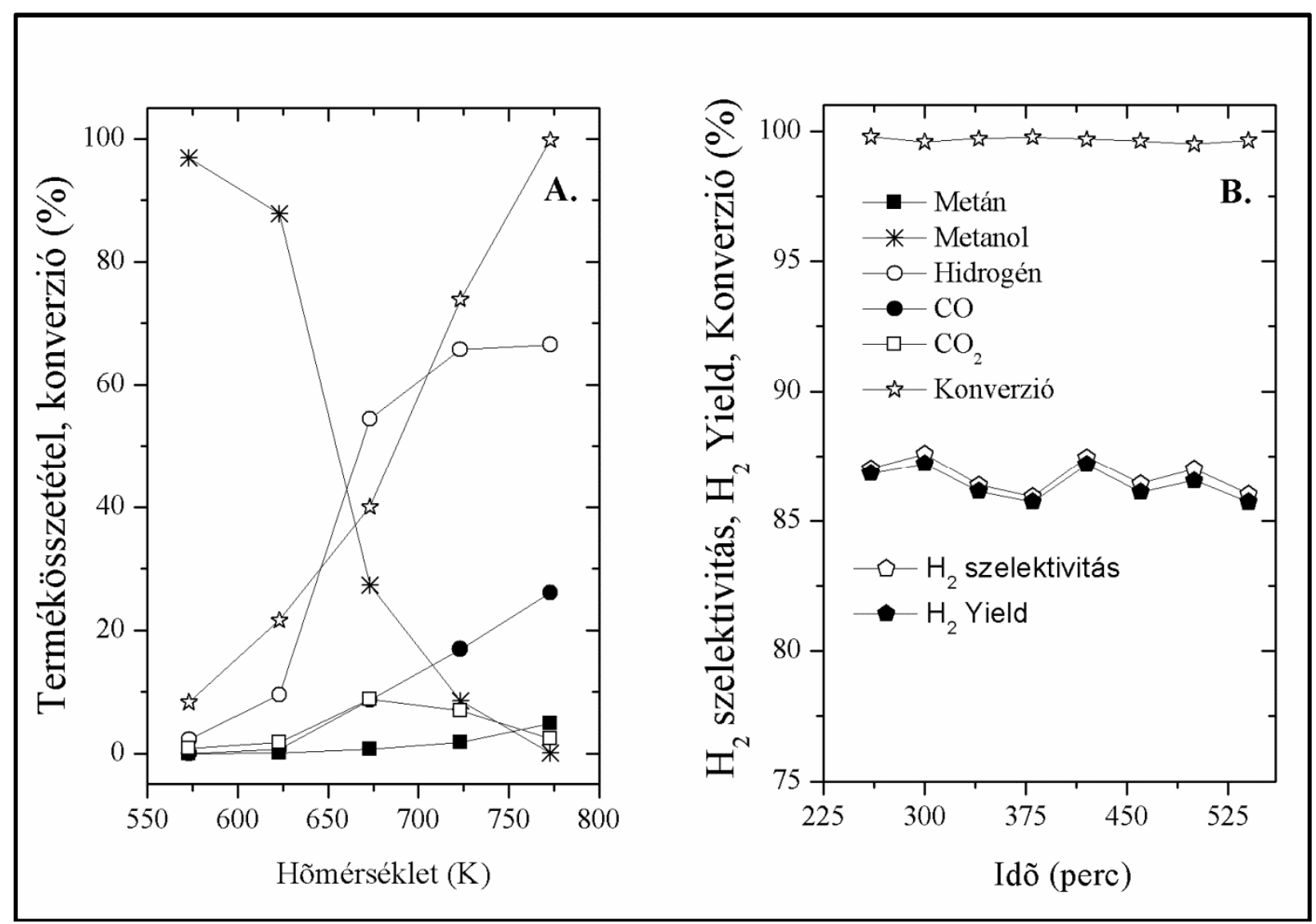

25. ábra $A$ DME reformálása során a konverzió és a termékösszetétel változása a hömérséklettel (A) valamint a $\mathrm{H}_{2}$ szelektivitás, a $\mathrm{H}_{2}$ yield és a konverzió az idö függvényében $773 \mathrm{~K}$-en (B) $1 \% \mathrm{~K}+1 \% \mathrm{Au} / \mathrm{CeO}_{2}+\mathrm{Al}_{2} \mathrm{O}_{3}$ (együttes impregnálás) katalizátort alkalmazva. 


\subsubsection{TPR mérések}

A katalitikus mérések befejezése után TPR méréseket végeztünk (26. ábra). Azt tapasztaltuk, hogy a felületi széntartalmú lerakódás mennyisége és reakcióképesség függ a reakcióhőmérséklettől. $773 \mathrm{~K}$-en 15 órás $1 \% \mathrm{Au} / \mathrm{CeO}_{2}-\mathrm{Al}_{2} \mathrm{O}_{3}$-on történő DME bontás után a felületi szén csak $700 \mathrm{~K}$ körül reagált hidrogénnel, nagy mennyiségű metán képződést eredményezve $(\mathrm{Tp}=830 \mathrm{~K})$ és sokkal kevesebb etánt valamint etilént $(\mathrm{Tp}=705-730 \mathrm{~K})$ (25.A ábra). A DME ugyanezen a katalizátoron történő ugyanilyen kísérleti körülmények közötti reformálása után hasonló vegyületek képződését azonosítottuk, de sokkal kisebb mennyiségben. A csúcs hőmérsékletek változatlanok maradtak (25.B ábra). Ez az eredmény azt sugallja, hogy a víz megakadályozza a széntartalmú vegyületek lerakódását, nagy valószínűséggel elreagálva a felületi széntartalmú anyagokkal.

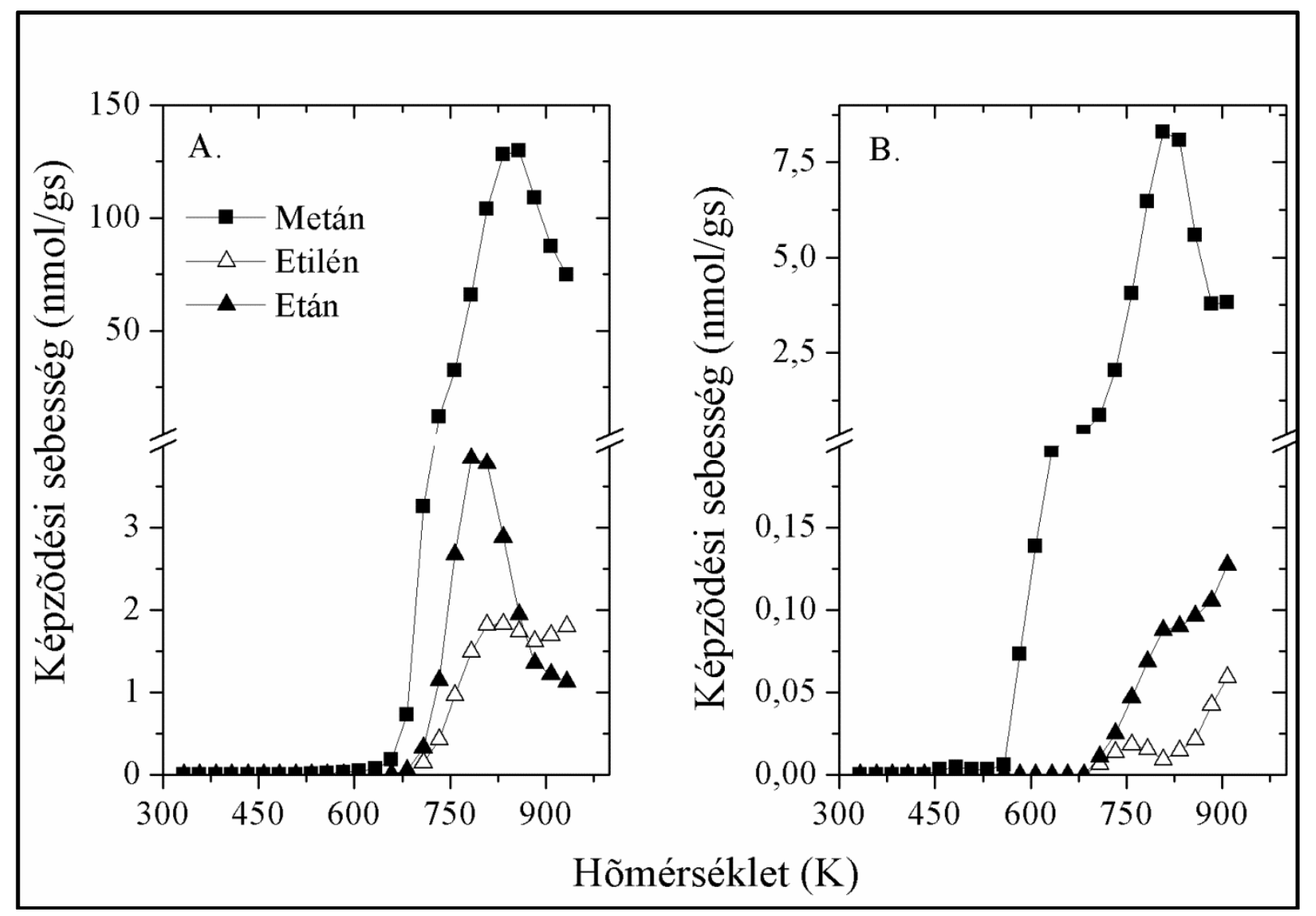

26. ábra $A$ DME 773 K-en történö 13 órányi bomlási (A) iletve. reformálási (B) reakciója után detektált TPR spektrum $1 \% \mathrm{Au} / \mathrm{CeO}_{2}+\mathrm{Al}_{2} \mathrm{O}_{3}$ (együttes impregnálás) katalizátoron 


\subsubsection{Eredmények értelmezése}

A dmietil-éter és a hordozós arany katalizátorok kölcsönhatásának megismerése érdekében a számos általunk kapott és a szakirodalomban lévő eredményeket hasonlítottunk össze. A DME adszorpcióját Au egykristályon még nem tanulmányozták. Viszont korábbi vizsgálataink során a $\mathrm{Rh}(111)$ esetében azt találtuk, hogy a DME 1,2 eV-al csökkenti a Rh kilépési munkáját jelezvén, hogy a DME-nek egy kifelé mutató pozitív dipólusmomentuma $\operatorname{van}^{134}$. A DME adszorpciójának rezgési módja jól megfelelt a gázfázisú értékeknek. 100 K-en történő DME adszorpcióját követő HREELS analízis során nem találtunk a DME adszorpciójára, disszociációjára jellemző spektrális sajátságot. Oxigén hozzáadása azonban egyértelműen metoxi-csoportokat jelzett HREEL spektroszkópiával ${ }^{134}$.

Feltételezzük, hogy a tömbi aranynak nem kellene nagyobb reaktivitást mutatnia a dimetil-éterrel, mint a ródiumnak. A helyzet azonban eltérő lehet az arany nanorészecskék esetében, amelyek sokkal nagyobb reakcióképességet mutatnak. Habár ezt nem könnyü bizonyítani, mivel a legtöbb oxidhordozó maga is aktiválhatja az adszorbeált DME molekulákat. Ezt az eredményt jól láttuk a tiszta és arany tartalmú oxidok IR spektrumaiban is. Más a helyzet szilícium-oxid hordozós arany és inert $\mathrm{SiO}_{2}$ esetében. TPD és FTIR méréseinkből kiderült, hogy a DME adszorpciója gyenge és nem disszociál a tiszta szilíciumdioxid felületén $300 \mathrm{~K}$-en: a deszorpció csúcs hőmérséklete Tp = $373 \mathrm{~K}$. A DME $300 \mathrm{~K}$-en történő adszorpcióját követve $5 \% \mathrm{Au} / \mathrm{SiO}_{2}$-n gyenge abszorpciós sávokat tudtunk azonosítani 2958 és $2853 \mathrm{~cm}^{-1}$-nél, amit a metoxi-csoportok rezgésének tulajdonítottunk a

$$
\left(\mathrm{CH}_{3}\right)_{2} \mathrm{O}_{(\mathrm{a})}=\mathrm{CH}_{3} \mathrm{O}_{(\mathrm{a})}+\mathrm{CH}_{3(\mathrm{a})}
$$

reakcióban. Ezek szerint az arany képes elősegíteni a DME-ben a C-O kötés hasadását Au$\mathrm{OCH}_{3}$ felületi komplexet eredményezve. A $2925 \mathrm{~cm}^{-1}$-es hullámszámnál detektált rezgés nagyon valószínű, hogy egy disszociálatlan DME-nek felel meg. Ugyanezt az abszorpciós sávot figyeltük meg a gázfázisú DME IR spektrumában és az $\mathrm{Al}_{2} \mathrm{O}_{3}$-on adszorbeálódott DME esetében is $150 \mathrm{~K}-\mathrm{en}^{131,132}$. A legintenzívebb abszorpciós sávok 2955, 2838, 2889, 1473, 1457 és $1071 \mathrm{~cm}^{-1}$-nél a $\mathrm{CeO}_{2}$-alapú mintákon a metoxi-csoportoknak tulajdonítható és nagy valószínúséggel a cériumon adszorbeálódtak. Mivel az adszorbeált $\mathrm{CH}_{3}$ csoportra jellemző spektrális tulajdonságokat nem tudtunk meghatározni ${ }^{113,114}$, nagyon valószínű, hogy a $\mathrm{CeO}_{2}$ oxigén atomjához kapcsolódott $\mathrm{Ce}-\mathrm{OCH}_{3}$ vegyületet létrehozva a felületen. $\mathrm{Az} \mathrm{Au} / \mathrm{CeO}_{2}$-ban 


\section{Mérési eredmények bemutatása és értelmezése}

az arany hatása a fentebbi abszorpciós sávok alacsonyabb stabilitásában nyilvánul meg, jelezve, a metoxi-csoportok adszorpciójának átvándorlását a cériumról az aranyra,ahol gyorsabban játszódik le a bomlásuk. Az 1583, 1375 és az $1315 \mathrm{~cm}^{-1}$-nél detektált sávokat a cériumon kialakult formiát-csoportoknak tulajdonítottuk:

$\mathrm{OH}_{(\mathbf{a})}+\mathrm{CO}_{(\mathbf{a})}=\mathrm{HCOO}_{(\mathbf{a})}$

A DME katalitikus reakciót vizsgálva összhangban a korábbi tanulmányainkkal azt találtuk, hogy a bomlás és a reformálás hordozós Au nanorészecskéken érzékenyen függ a hordozó természetétől. $\mathrm{Az} \mathrm{Au} / \mathrm{CeO}_{2}$ volt a legaktívabb a metanol és az etanol reakcióiban. $\mathrm{A}$ metanol esetében a hidrogénképződés yieldje elérte a 93\%-ot 773 K-en. Míg az adszorbeált etanol esetében a $\mathrm{C}$ - $\mathrm{C}$ kötés csak korlátozott mértékben szakadt még $\mathrm{Au} / \mathrm{CeO}_{2}$-on is, így a hidrogén képződése sokkal kisebb volt. Ez a jelleg megjelent a jelen esetben is, itt hasonlóan a C-O kötés szakadás lehet a leglassabb lépés a $\mathrm{DME}$ bomlásában $\mathrm{Au} / \mathrm{CeO}_{2}$-on: a $\mathrm{DME}$ konverziója viszonylag alacsony értéken maradt, 20\% körül még $773 \mathrm{~K}$-en is (22.A ábra). Mindazonáltal, a hidrogénképződésre vonatkozóan, az $\mathrm{Au} / \mathrm{CeO}_{2}$ mutatta a legnagyobb aktivitást a vizsgált $\mathrm{Au}$ minták közül. Ellentétben az $\mathrm{Au} / \mathrm{Al}_{2} \mathrm{O}_{3}$-al, ami hatékonyan katalizálta a DME bomlását (22.B ábra), a legfontosabb reakció út alapvetően különböző volt. Az utóbbi esetben az elsődleges termék a metanol volt, ami a DME hidrolízisét sugallja az alumíniumoxid $\mathrm{OH}-c s o p o r t j a ́ n a k$ részvételével

$\mathrm{CH}_{3}-\mathrm{O}-\mathrm{CH}_{3(\mathrm{~g})}+\mathrm{OH}_{(\mathrm{a})}=2 \mathrm{CH}_{3} \mathrm{OH}_{(\mathrm{g})}$

$\mathrm{CeO}_{2}+\mathrm{Al}_{2} \mathrm{O}_{3}$ vegyes oxidot használva az $\mathrm{Au}$ nanorészecskék hordozójaként magasabb hidrogén képződési sebességet eredményezett mind a DME bomlása, mind pedig reformálása során. Ez a magas aktivitás az $\mathrm{Al}_{2} \mathrm{O}_{3}$ hidratációs tulajdonságának, az ebből következő metanol képződésnek és az $\mathrm{Au}-\mathrm{CeO}_{2}$ felület magas reakcióképességének köszönhető a metanol aktiválásában és bomlásában

$$
\mathrm{CH}_{3} \mathrm{OH}=\mathrm{CO}+2 \mathrm{H}_{2}
$$

A metanol bomlásában az $\mathrm{Au} / \mathrm{CeO}_{2}$ magas aktivitásának feltehető okait az előzőekben már rélszletesen tárgyaltuk. Figyelembe véve a DME gyors konverzióját metanollá a vegyes 


\section{Mérési eredmények bemutatása és értelmezése}

katalizátorokon és a könnyen végbemenő metoxi-csoport képződést metanolból, azt feltételezzük, hogy a DME-böl képződő hidrogén leglassabb lépése $\mathrm{Au} / \mathrm{CeO}_{2}+\mathrm{Al}_{2} \mathrm{O}_{3}$ katalizátoron a metoxi-csoportban az egyszeres C-H kötések hasadása

$\mathrm{CH}_{3} \mathrm{O}_{(\mathbf{a})}=\mathrm{CH}_{2} \mathrm{O}_{(\mathbf{a})}+\mathrm{H}_{(\mathbf{a})}$

Káliumot adva az $\mathrm{Au} / \mathrm{CeO}_{2}+\mathrm{Al}_{2} \mathrm{O}_{3}$ katalizátorhoz a DME reformálása során a hidrogénképződés tovább gyorsult, ami talán a kálium promotáló hatásának tulajdonítható a víz-gáz reakcióban,

$\mathrm{CO}+\mathrm{H}_{2} \mathrm{O}=\mathrm{CO}_{2}+\mathrm{H}_{2}$

amelyet jól katalizálnak a $\mathrm{CeO}_{2}$ hordozós fém katalizátorok és a $\mathrm{Mo}_{2} \mathrm{C}^{133}$. Tény az, hogy a metán tartalom is redukálódott a $\mathrm{K}$ adalékolt mintákon ezt jelezte a metán reformálásának fokozott sebessége

$\mathrm{CH}_{4}+\mathrm{H}_{2} \mathrm{O}=\mathrm{CO}+3 \mathrm{H}_{2}$

Arra mutattunk rá, hogy a kálium elektron donorként viselkedik az adszorbeált vizzel és a CO-dal, aktiválni tudja ezeket a molekulákat, így azok reakciójában magasabb képződést eredményezve $^{135}$. 


\section{Mérési eredmények bemutatása és értelmezése}

\subsubsection{Föbb konklúziók}

(i) Az FTIR spektroszkópiás mérésekből kiderült, hogy oxid hordozós $\mathrm{Au}$ katalizátorokon a DME bomlásában metoxi-csoportok képződnek.

(ii) A DME bomlásának iránya Au katalizátorokon függ a hordozó természetétől. Még $\mathrm{Au} / \mathrm{CeO}_{2}$ katalizátorok hidrogén képződést eredményeznek, addig az $\mathrm{Au} / \mathrm{Al}_{2} \mathrm{O}_{3}$-on lejátszódó legfőbb folyamat a DME hidrolízise. Kombinálva ezeket a tulajdonságokat, $\mathrm{Au} / \mathrm{CeO}_{2}+\mathrm{Al}_{2} \mathrm{O}_{3}$ minta egy nagyon hatékony katalizátorhoz vezetett a hidrogénképződés szempontjából a DME bomlási és reformálási reakcióiban.

(iii) A magas aktivitást a könnyü metanol képződésnek tulajdonítottuk alumínium-oxidon és az $\mathrm{Au} / \mathrm{CeO}_{2}$ felület magas aktivitásának a képződött metanol tovább bomlásában.

(iv)Káliumot adva ehhez a katalizátorhoz promotálja a hidrogén képződését. 


\subsubsection{Hangyasav vizsgálata}

\subsubsection{Infravörös spektroszkópiás mérések}

Az 27. ábrán ábrázoltuk az adszorbeált és a különböző hőmérsékletekhez tartozó hangyasav IR spektrumát $\left(\mathrm{T}_{\mathrm{R}}=673 \mathrm{~K}\right)$ különböző mintákon és folyamatos szívatás közben. $1 \% \mathrm{Au} / \mathrm{CeO}_{2}$-on abszorpciós sávokat figyeltünk meg 2928, 2857 és $2727 \mathrm{~cm}^{-1}$-nél a C-H rezgési tartományban. Alacsony frekvencia tartományban 1640 és $1500 \mathrm{~cm}^{-1}$ közötti széles abszorpciós sajátság 1637, 1586 és $1536 \mathrm{~cm}^{-1}$-es csúcsokra bontható fel. Jól detektálható abszorpciós sávok is megjelentek 1391, 1316,1248 és $1081 \mathrm{~cm}^{-1}$-nél. Nagyobb mennyiségü $\mathrm{HCOOH}$ esetén egy $1728 \mathrm{~cm}^{-1}$-nél is láttunk sajátságot (nem látható az ábrán). A minta fútése az összes sáv csökkenését okozta, valamint az $1728 \mathrm{~cm}^{-1}$-es sáv eltűnését még 373 K-nél. Gyakorlatilag azonos spektrumot kaptunk a hangyasav adszorpcióját követően tiszta $\mathrm{CeO}_{2}$-on, azzal a különbséggel, hogy a sávok sokkal stabilabbak voltak. $\mathrm{Az} 1 \% \mathrm{Au} / \mathrm{SiO}_{2}$-re kapott eredmények vizsgálata során megállapítottuk, hogy magasabb frekvencia tartományban majdnem azonos adszorpciós sávokat kaptunk, mint az előző katalizátorokon. Detektáltunk egy sávot $1733 \mathrm{~cm}^{-1}$-nél, egy nagyon intenzív elnyelési sávot $1602 \mathrm{~cm}^{-1}$-nél és egy kevésbé intenzívet 1377 és $1361 \mathrm{~cm}^{-1}$-nél is. Ha az adszorpciós réteget folyamatos szívatás közben fütjük, az $1733 \mathrm{~cm}^{-1}$-es sáv eltünik $523 \mathrm{~K}$-nél, de az $1602 \mathrm{~cm}^{-1}$-nél lévő spektrális sajátság még detektálható $573 \mathrm{~K}$-nél is. Ha az Au tartalmat 5\%-ra növeljük, akkor az 1600, 1377 és az $1361 \mathrm{~cm}^{-1}$-nél lévő alacsony frekvencia sávok intenzitása némileg erősebb lett, de azok hőstabilitása változatlan maradt. Az Au mentes tiszta hordozók IR mérései nagyon hasonló spektrumokat eredményeztek, a $\mathrm{SiO}_{2}$ kivételével, ahol nem jelent meg adszorpciós sáv 1700$1500 \mathrm{~cm}^{-1}$ között. A 7. táblázat tartalmazza a hangyasav és a formiát jellegzetes rezgéseit azok lehetséges jelöléseivel együtt. 


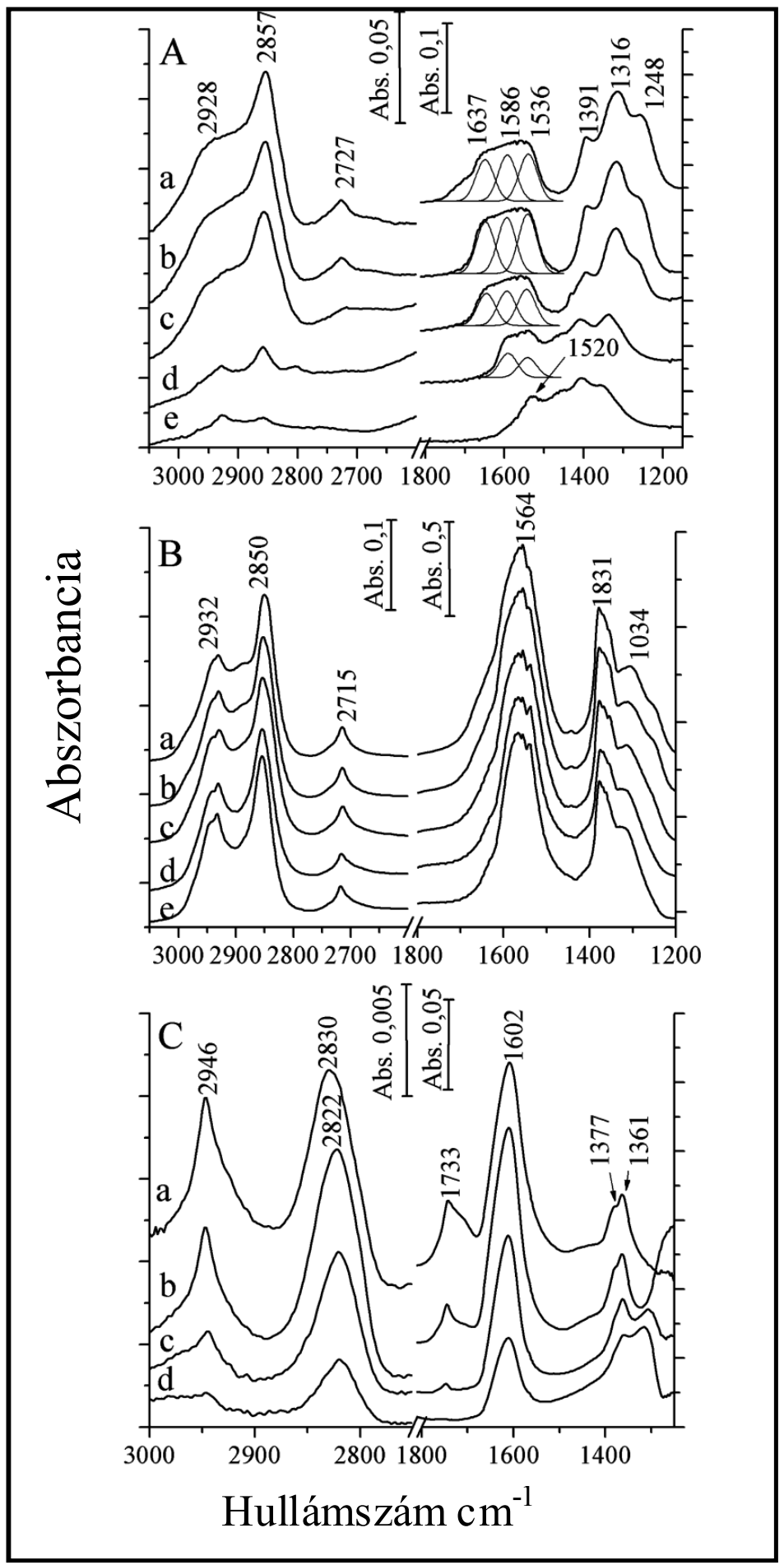

27. ábra $A$ HCOOH $300 \mathrm{~K}$-en történö adszorpciójának FTIR spektruma $1 \% \mathrm{Au} / \mathrm{CeO}_{2}$-on (A), $\mathrm{CeO}_{2}$-on (B) és $1 \% \mathrm{Au} / \mathrm{SiO}_{2}$-on (C) és különbözö hömérsékletekre felfütve folyamatos szivatás közben: $a, 300 \mathrm{~K} ; b, 373 \mathrm{~K} ; \mathrm{c}, 473 \mathrm{~K} ; d, 523 \mathrm{~K} ; \mathrm{e}, 573 \mathrm{~K}$ 
7. táblázat $A$ hangyasav disszociatív adszorpciója során kialakuló vibrációs rezgések ( $\mathrm{cm}^{-1}$-ben kifejezve)

\begin{tabular}{lccc}
\hline \multicolumn{1}{c}{ Jellemző rezgések } & $\mathbf{C e O}_{\mathbf{2}}$ & $\mathbf{A u} / \mathbf{C e O}_{\mathbf{2}}$ & $\mathbf{A u} / \mathbf{S i O}_{\mathbf{2}}$ \\
\hline$v_{\mathrm{a}}(\mathrm{OCO})$ és CH def. & 2953 & & \\
$v(\mathrm{CH})$ hangyasav & 2928 & 2928 & 2946 \\
$v(\mathrm{CH})$ & 2871 & 2857 & 2830 \\
$v_{\mathrm{a}}(\mathrm{OCO})+\delta_{\mathrm{a}}(\mathrm{CH})$ & 2737 & 2727 & \\
$v(\mathrm{O})$ & 1668 & 1637 & \\
$v_{\mathrm{a}}(\mathrm{OCO})$ & 1555 & 1586 & 1602 \\
$v_{\mathrm{s}}(\mathrm{OCO})$ & 1386 & 1391 & 1377 \\
$v_{\mathrm{s}}(\mathrm{OCO})$ & 1369 & 1316 & 1361 \\
$\mathrm{CO}$ & 1288 & 1248 & \\
\hline
\end{tabular}
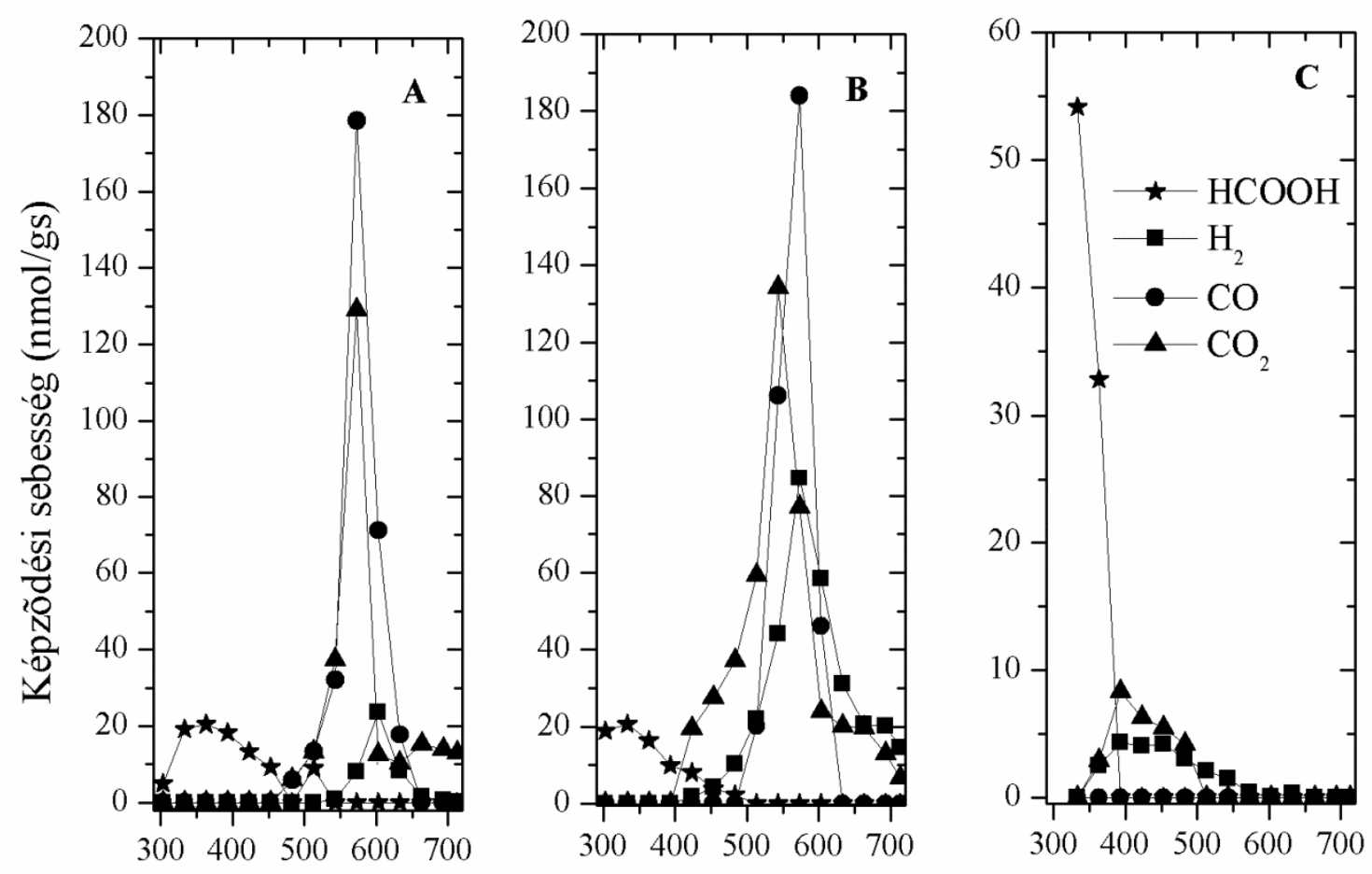

Hõmérséklet (K)

28. ábra $A$ hangyasav $300 \mathrm{~K}$-en történö adszorpcióját követö TPD spektrumok $1 \% \mathrm{Au} / \mathrm{CeO}_{2}$-on (A), tiszta $\mathrm{CeO}_{2}$-on (B) és $1 \% \mathrm{Au} / \mathrm{SiO}_{2}-n$ 
A hangyasav katalizátorokon való adszorpciója után kapott különböző termékek TPD spektrumai a 28. ábrán láthatóak. Az adszorbeálódott hangyasav deszorpciója nagyon alacsony volt tiszta $\mathrm{CeO}_{2}$-on, $300 \mathrm{~K}$ felett kezdődött és $450 \mathrm{~K}$-ig folyamatos volt. Az egyéb termékek deszorpciója $\left(\mathrm{CO}\right.$ és $\left.\mathrm{CO}_{2}\right) 500 \mathrm{~K}$ felett indult el, $570 \mathrm{~K}$ körül eredményezve egy maximumot. Sokkal kisebb $\mathrm{H}_{2}$ mennyiséget mértünk $\mathrm{T}_{\mathrm{P}}=600 \mathrm{~K}$. Hasonló TPD spektrumot kaptunk $1 \% \mathrm{Au} / \mathrm{CeO}_{2}$ esetében, azzal a különbséggel, hogy a hidrogénfejlődés már $400 \mathrm{~K}$ fölött megfigyelhető volt és szélesebb TPD csúcsot kaptunk. Eltérő TPD görbéket regisztráltunk $\mathrm{Au} / \mathrm{SiO}_{2}$ és $\mathrm{Au} /$ norit (nem látható) esetében, ahol a gyengén kötött hangyasav mellett csak kis mennyiségü $\mathrm{CO}_{2}$ és $\mathrm{H}_{2}$ deszorbeálódott 350 és $500 \mathrm{~K}$ között $\mathrm{CO}$ nélkül.

\subsubsection{Katalitikus mérések}

A 29.A ábrán látható a hangyasav konverziója különböző hordozós $1 \%$ Au tartalmú anyagokon. Jól látszik, hogy az Au katalizátorok katalitikus teljesítményét markánsan befolyásolja a hordozó természete, amely az eddigi mérésekkel is teljesen összhangban van.

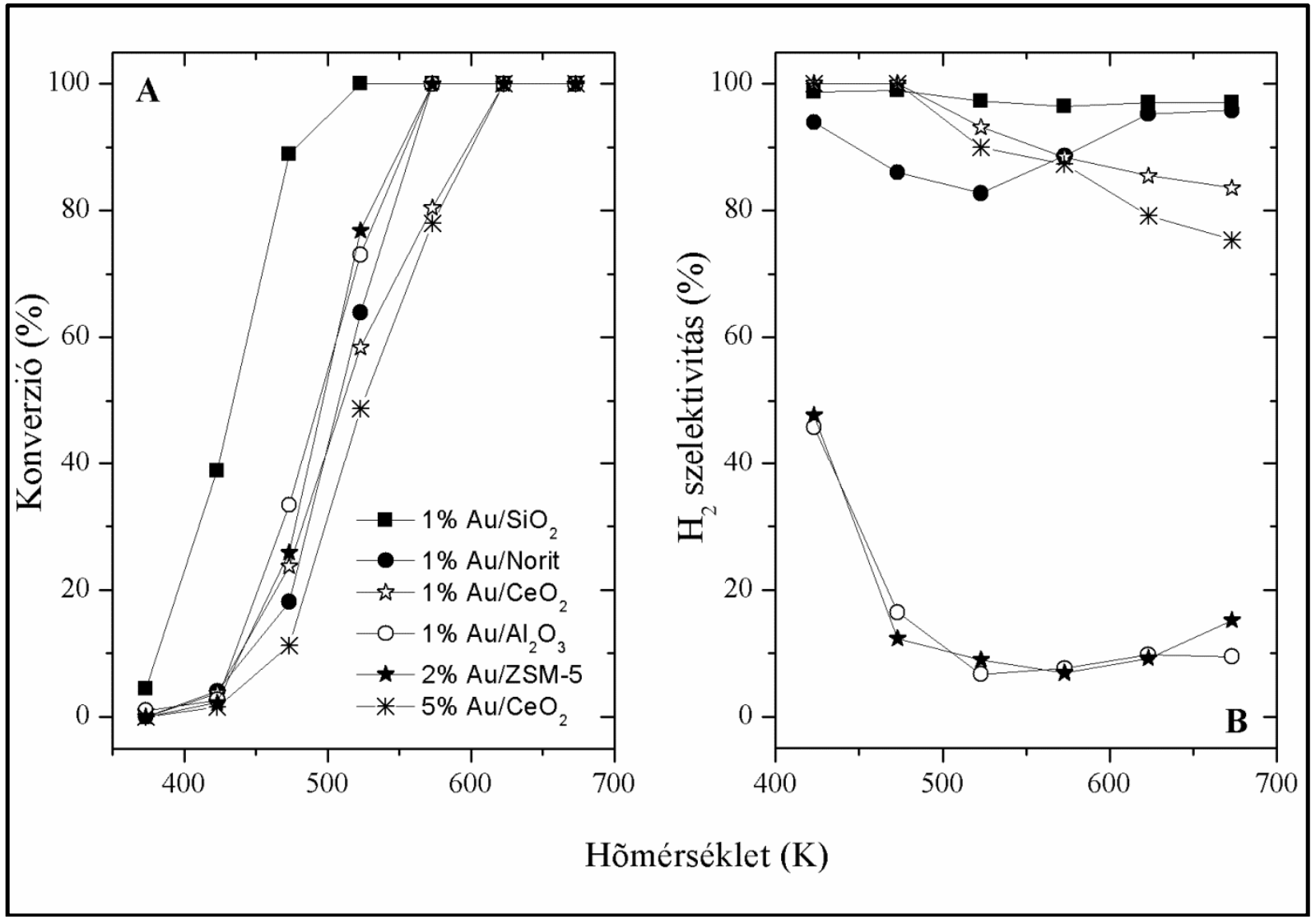

29. ábra A hangyasav konverziója (A) és a képzödött hidrogén szelektivitása (B) különbözö hordozós Au katalizátorokon a hömérséklet függvényében 
A legaktívabb katalizátoron, az $\mathrm{Au} / \mathrm{SiO}_{2}$-n, a bomlás $373 \mathrm{~K}$-nél kezdődik és a teljes konverziót 523 K-nél éri el. Nagyon kis különbség van a különböző arany minták hatékonyságában. Érdekes módon a $\mathrm{CeO}_{2}$-on az $\mathrm{Au}$ tartalom tovább növelése 5\%-ra

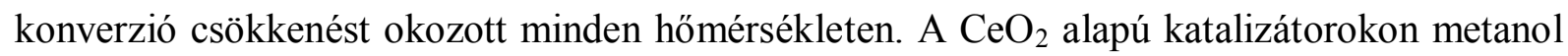
és formaldehid nyomokat is detektáltunk.

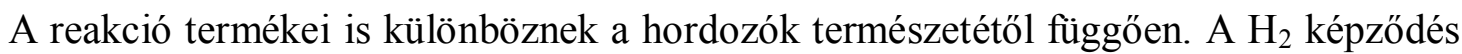
szelektivitása $\mathrm{Au} / \mathrm{CeO}_{2}$-on $100 \%$ volt $423-473 \mathrm{~K}$ között, de magasabb hömérsékleteken csökkent. $\mathrm{Az} \mathrm{Au} / \mathrm{SiO}_{2}-\mathrm{n}$ is $100 \%$ volt a szelektivitás $373 \mathrm{~K}$-en, ami 98\%-ra csökkent 423-473 K között és 97\%-ra $523 \mathrm{~K}$-en, ahol a hangyasav bomlása teljessé vált. Magas szelektivitást mértünk az $\mathrm{Au} /$ noriton is (95-84\%). A legalacsonyabb értéket (kb. 10\%) az $\mathrm{Au} / \mathrm{Al}_{2} \mathrm{O}_{3}$ és az Au/ZSM-5 esetében találtuk. A hidrogénképződés szelektivitásának hőmérsékletfüggése a 29.B ábrán ábrázoltuk.

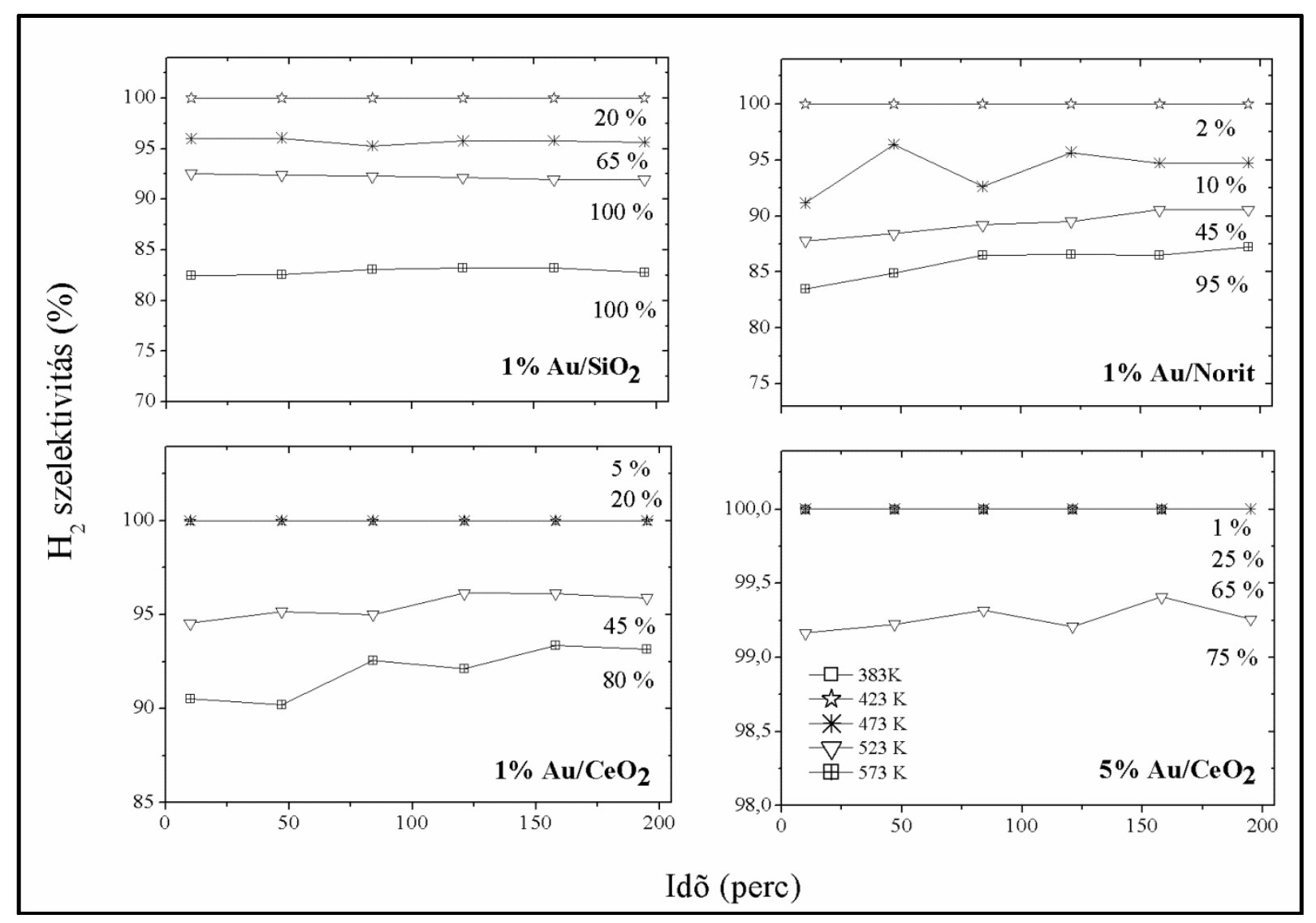

30. ábra A hangyasav bomlása során képzödött hidrogén szelektivitása különbözö hordozós Au katalizátorokon az idö függvényében különbözö hömérsékleteken a hangyasav konverziójának feltüntetésével (\%-ban) 
A hömérséklet hatásának meghatározása után a hangyasav bomlását időben követtük 623-673 K közötti hőmérsékletintervallumban a teljes bomlás szakaszában. Csak kis mértékü csökkenést tapasztaltunk a hangyasav konverziójában és a $\mathrm{H}_{2}$ képződés szelektivitásában körül-belül 7 órás mérési intervallumokban. Magas stabilitást találtunk alacsonyabb hőmérsékleteken, ahol a hidrogén szelektivitás magasabb volt. $\mathrm{CO}$-mentes $\mathrm{H}_{2}$-t kaptunk 1\% $\mathrm{Au} / \mathrm{SiO}_{2}$-n és 1-5\% Au/ $\mathrm{CeO}_{2}$-on 383-473 $\mathrm{K}$ között. A mért szelektivitás adatokat a 30. ábrán jelenítettük meg. CO hozzáadásának hatására gyakorlatilag semmilyen változást nem tapasztaltunk sem a konverzióban sem a $\mathrm{H}_{2}$ szelektivitásban.

Hasonló méréseket hajtottunk végre a tiszta oxid hordozókkal, amelyeket ugyanúgy kezeltünk, mint az Au tartalmú mintákat. Összhangban a korábbi tanulmányokkal ${ }^{75,76}$, a hangyasav bomlása a tiszta oxidokon is megtörtént, föként a dehidratációs folyamat játszódott le. A konverzió még $523 \mathrm{~K}$-nél is $5-15 \%$ alatt maradt, ami tisztán jelzi az Au jelentős katalitikus hatását. Néhány fontos adatot a hangyasav bomlásáról különbözö katalizátorokon a 8. táblázat mutatva be. Figyelembe véve a hordozós Au diszperzitás értékeit a fajlagos aktivitást turnover frekvenciába $\left(\mathrm{N}_{\mathrm{H} 2}\right.$, a felületi Au atomra vonatkoztatva) átszámolva fejeztük ki $473 \mathrm{~K}$-en. Ez a következő sorrendet adta: $\mathrm{Au} / \mathrm{SiO}_{2}, \mathrm{Au} /$ norit, $\mathrm{Au} / \mathrm{CeO}_{2}, \mathrm{Au} / \mathrm{ZSM}-5$ és $\mathrm{Au} / \mathrm{Al}_{2} \mathrm{O}_{3}$.

8. táblázat $A$ különbözö hordozós katalizátorok arany tartalmának átlagos részecskemérete, diszperzitása, valamint a hangyasav bonlásának és a hidrogénképzödésnek a turnover frekvenciái

\begin{tabular}{ccccc}
\hline Katalizátor & $\begin{array}{c}\text { Átlagos } \\
\text { részecskeméret } \\
(\mathbf{n m})\end{array}$ & Diszperzitás & $\begin{array}{c}\mathbf{T O F}\left(\mathbf{H}_{2}\right) \mathbf{s}^{-1} \\
\mathbf{4 7 3} \mathbf{K}\end{array}$ & $\begin{array}{c}\mathbf{T O F}(\mathbf{H C O O H}) \mathbf{s}^{-\mathbf{1}} \\
\mathbf{4 7 3} \mathbf{K}\end{array}$ \\
\hline $\mathbf{1 \%} \mathbf{A u} / \mathbf{S i O}_{\mathbf{2}}$ & 6,5 & 0,2 & 1,951 & 2,082 \\
$\mathbf{1 \%} \mathbf{A u} / \mathbf{n o r i t}$ & 5,7 & 0,3 & 0,297 & 0,317 \\
$\mathbf{1 \%} \mathbf{A u} / \mathbf{C e O}_{2}$ & 1,9 & 0,7 & 0,082 & 0,119 \\
$\mathbf{1 \%} \mathbf{A u} / \mathbf{A l}_{\mathbf{2}} \mathbf{O}_{\mathbf{3}}$ & 5,5 & 0,25 & 0,005 & 0,439 \\
$\mathbf{1 \%} \mathbf{A u} / \mathbf{Z S M}_{\mathbf{S O}}$ & 3,3 & 0,43 & 0,027 & 0,002 \\
\hline
\end{tabular}




\section{Mérési eredmények bemutatása és értelmezése}

Ahhoz, hogy megállapítsuk, hogy milyen adszorbeált formák vannak a felületen dinamikus körülmények között, FTIR spektroszkópiás tanulmányokat hajtottunk végre in situ a katalitikus reakció alatt $\mathrm{HCOOH}+\mathrm{Ar}$ gázkeveréket áramoltatva 383-523 K között. A kapott spektrumokat a 31. ábrán mutattuk be. $1 \% \mathrm{Au} / \mathrm{CeO}_{2}$-on intenzív abszorpciós sávok mellett a hangyasavnak megfelelő $1720-1730 \mathrm{~cm}^{-1}$ sávot is tapasztaltuk (az ábrán nem látható), intenzív spektrális tulajdonságok jelentek meg 1635, 1557, 1388, 1344, 1205 és $1125 \mathrm{~cm}^{-1}$-nél $383 \mathrm{~K}$ en. A reakcióhőmérsékletet emelve 423-523 K között, új abszorpciós sáv jelent meg 1425 és $1409 \mathrm{~cm}^{-1}$-nél, a többi sáv változatlan maradt (31.A ábra). Ha a gázelegyet tiszta Ar-ra cseréltük azt tapasztaltuk, hogy csak enyhén csökkent ezeknek az abszorpciós sávoknak az intenzitása. Hasonló eredményt kaptunk tiszta $\mathrm{CeO}_{2}$ esetében, viszont sokkal erősebb rezgést találtunk $1565 \mathrm{~cm}^{-1}$-nél (31.B ábra). Ellenben az $1 \% \mathrm{Au} / \mathrm{SiO}_{2}$ esetében jól látható különbséget kaptunk. A hangyasav molekula $1750 \mathrm{~cm}^{-1}$-es spektrális jellemzőjén kívül csak gyenge abszorpciós sávok jelentek meg 1584, 1351, 1288, 1216, 1140 és $1085 \mathrm{~cm}^{-1}$-nél (31.C ábra).

$1 \% \mathrm{Au} / \mathrm{SiO}_{2}$-n kinetikai méréseket is végeztünk kis konverzióknál, $10 \%$ alatt. A hangyasav parciális nyomását változtattuk a teljes áramlási sebességet $40 \mathrm{ml} / \mathrm{min}$ állandó értéken tartva Ar gázt adva a rendszerhez. A hangyasav reakciójának hőmérsékletét 393-433 $\mathrm{K}$ tartományon belül változtatva, ezen körülmények között a reakció nullad rendủ kinetikát követett. Az Arrhenius görbéből számolt hangyasav bomlására vonatkozó aktiválási energia $60,7 \mathrm{~kJ} / \mathrm{mol}$, a hidrogénképződésé pedig $58,5 \mathrm{~kJ} / \mathrm{mol}$ volt. 


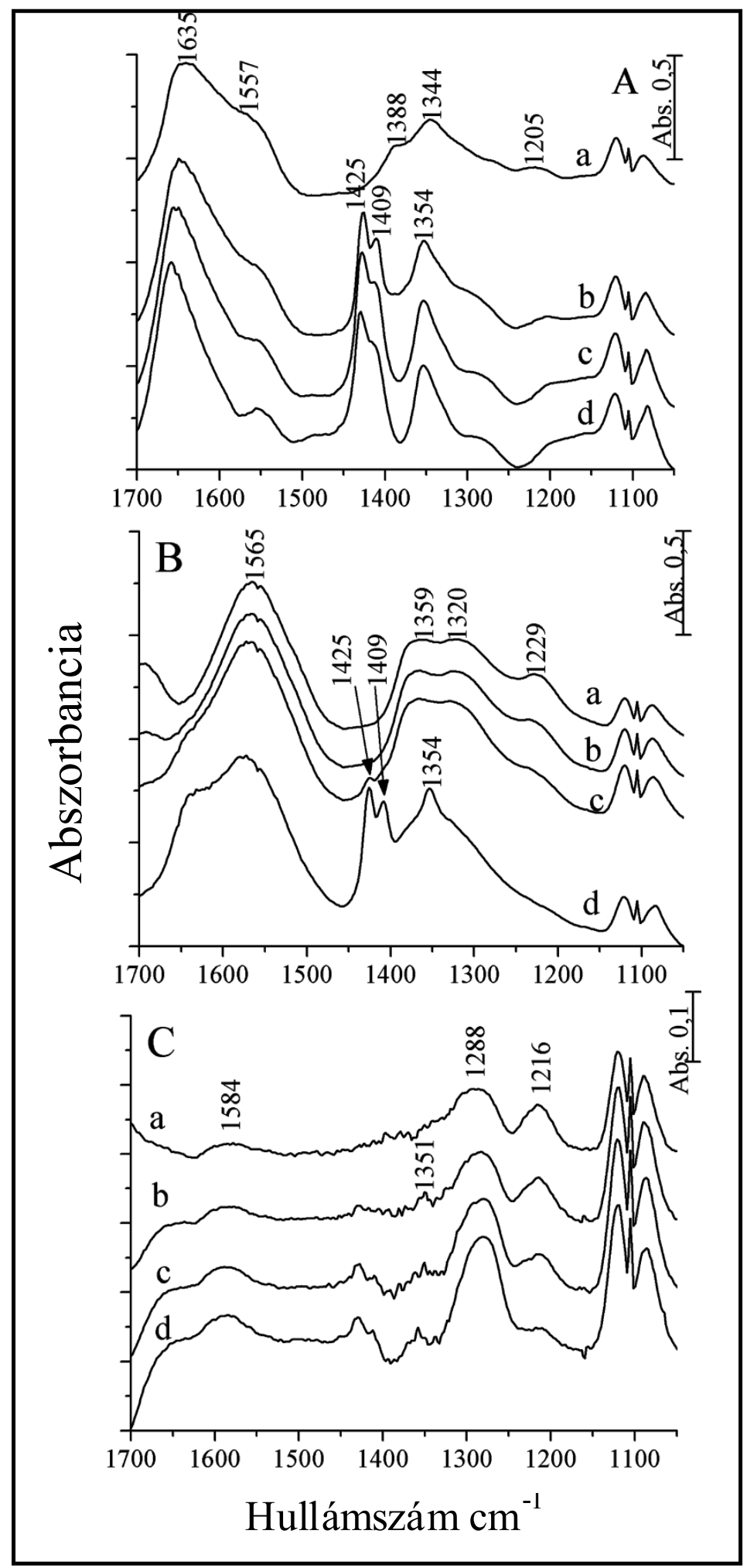

31. ábra A hangyasav bomlása során kapott in situ IR spektrumok különbözö hömérsékleteken $1 \% \mathrm{Au} / \mathrm{CeO}_{2}$-on (A), $\mathrm{CeO}_{2}$-on (B) és $1 \% \mathrm{Au} / \mathrm{SiO}_{2}$-on (C):

$a, 383 K$; b, $423 K$; c, $473 K$; $d, 523 K$ 


\subsubsection{Hangyasav reformálása}

Víz hozzáadásának hatása a hangyasavhoz annak konverzióját csak némileg befolyásolta a legtöbb katalizátor esetében. A hangyasav bomlását követtük időben 383 és 573 K hőmérsékletek között. A különböző katalizátorokra vonatkozó adatok azt mutatták, hogy a kisebb ingadozásoktól eltekintve nagy változás nem történt (32. ábra).

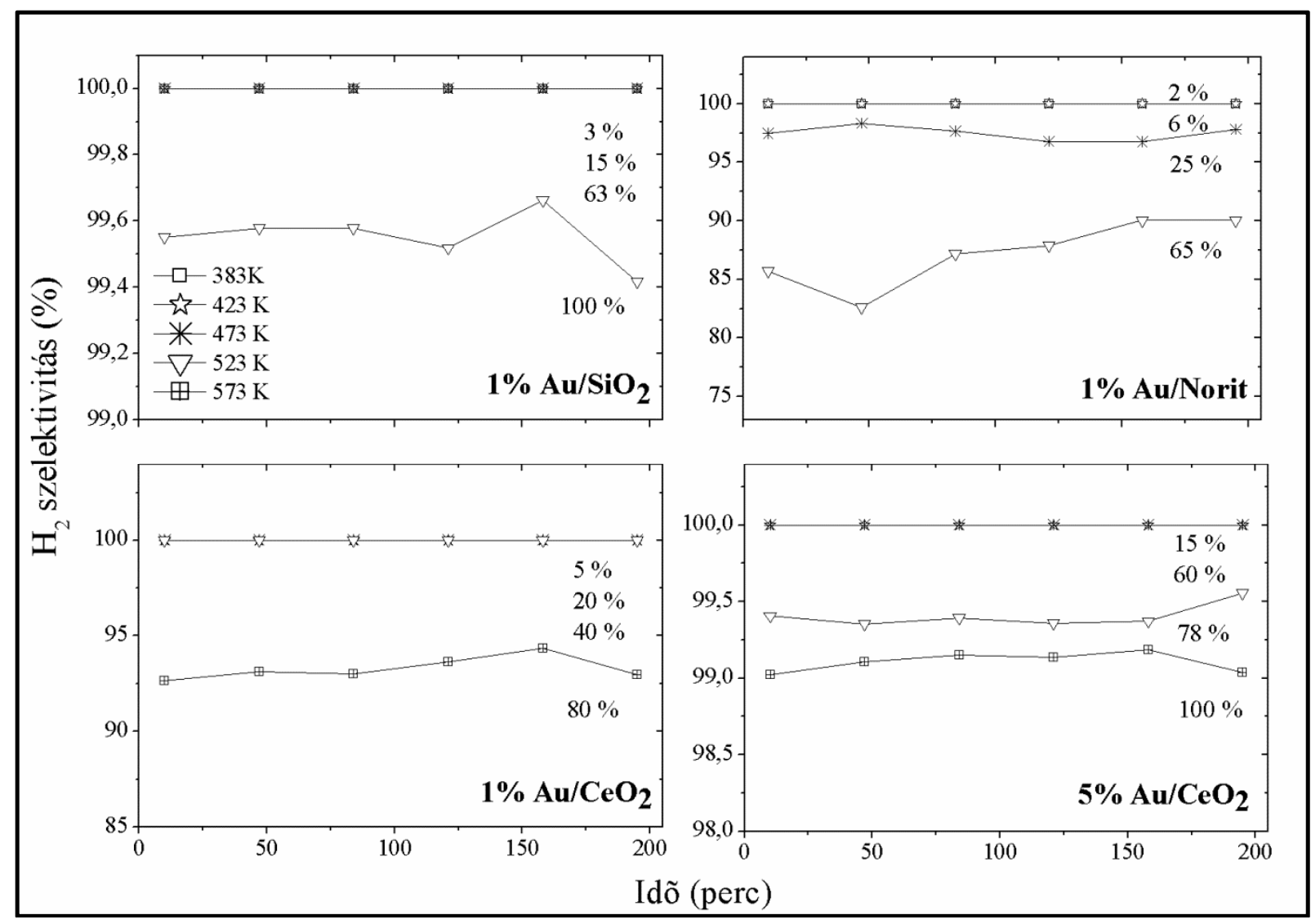

32. ábra $A$ hangyasav reformálása $\left(\mathrm{HCOOH} / \mathrm{H}_{2} \mathrm{O}=1\right)$ során képzödött hidrogén szelektivitása különbözö hordozós Au katalizátorokon az idö függvényében különbözö hömérsékleteken a hangyasav konverziójának feltüntetésével (\%-ban)

A hidrogénszelektivitás a bomlási reakciók során is nagyon magas volt $(100 \%)$ alacsony hőmérsékleten, így a víz pozitív hatása többnyire magasabb reakcióhőmérsékleteken látszódott. A katalizátorok hidrogénképződésben való hatékonyságának megítéléséhez és pontosabb összehasonlíthatóságuk érdekében kiszámítottuk a $\mathrm{H}_{2}$ képződés yieldjét. A különböző mintákhoz tartozó eredmények a 9. táblázatban lettek feltüntetve. A legmagasabb 
yield értéket $(99,5 \%)$ az $\mathrm{Au} / \mathrm{SiO}_{2}$-n kaptuk $523 \mathrm{~K}$-en, ezt jól megközelíti az 5\% $\mathrm{Au} / \mathrm{CeO}_{2}$-on kapott érték is.

9. táblázat Néhány jellemzö adat a hangyasav reformálása során képzödött hidrogénképzödésre különbözö hordozós arany katalizátorokon

\begin{tabular}{lcccc}
\hline Katalizátor & Hőmérséklet (K) & Konverzió (\%) & $\begin{array}{c}\mathbf{H}_{2} \text { szelektivitás } \\
(\%)\end{array}$ & $\mathbf{H}_{\mathbf{2}}$ yield \\
\hline $\mathbf{1 \%} \mathbf{A u} / \mathbf{S i O}_{\mathbf{2}}$ & 383 & 3 & 100 & 3 \\
& 423 & 15 & 100 & 15 \\
& 473 & 63 & 100 & 63 \\
& 523 & 100 & 99,5 & 99,5 \\
\hline $\mathbf{1 \%} \mathbf{A u} /$ norit & 383 & 2 & 100 & 2 \\
& 423 & 7 & 100 & 7 \\
& 473 & 25 & 97 & 24,2 \\
& 523 & 66 & 88 & 58 \\
\hline $\mathbf{1 \%} \mathbf{A u} / \mathbf{C e O}_{2}$ & 383 & 6 & 100 & 6 \\
& 423 & 18 & 100 & 18 \\
& 473 & 43 & 100 & 43 \\
& 523 & 75 & 93 & 69,7 \\
\hline $\mathbf{5 \%} \mathbf{A u} / \mathbf{C e O}_{2}$ & 383 & 16 & 100 & 16 \\
& 423 & 60 & 100 & 60 \\
& 473 & 78 & 99,4 & 77,5 \\
& 523 & 100 & 99 & 99 \\
\hline
\end{tabular}

\subsubsection{Eredmények értelmezése}

A hangyasav adszorpciója a legtöbb oxid hordozós Au katalizátorokon intenzív abszorpciós sávokat eredményezett az IR spektrumokban (27. ábra). A legfontosabb spektrális jellemzők 1555-1600 és 1386-1361 cm' tartományú sávok voltak. Az első a formiát aszimmetrikus rezgésének, a második pedig a szimmetrikus rezgésének tulajdonítható $^{136}$. Ezek az eredmények jelezték, hogy a hangyasav disszociációja lejátszódik ezeken a mintákon.

A formiát helyét illetően fontos kiemelni, hogy nagyon hasonló spektrumokat vettünk fel $\mathrm{Au}$ mentes $\mathrm{Al}_{2} \mathrm{O}_{3}$ és $\mathrm{CeO}_{2}$ tiszta hordozókon. Ezzel összevethető képet kaptunk a hangyasav adszorpcióját vizsgáló hordozós Rh tartalmú katalizátorokon végzett korábbi 
tanulmányokban ${ }^{5}$. Ez vezetett ahhoz a feltevéshez, hogy a formiát az oxid hordozóhoz kötődik. Ezt az elképzelést megerősítettük a formiát csoportok számának meghatározásával, ami 5-8-szor több volt, mint a felületen lévő Rh atom. A feltevésre további bizonyítékot adott az IR eredmény $\mathrm{Rh} / \mathrm{SiO}_{2}-\mathrm{n}$, ahol nem azonosítottunk formiátra jellemző sávokat a hangyasav $300 \mathrm{~K}$-en történő adszorpcióját követően. Ez arra engedett következtetni, hogy a $\mathrm{SiO}_{2}$-n nincs formiát és ezt a jelen tanulmány is megerősítette. Formiátot detektáltak $\mathrm{Rh}(111)$ egykristályon nagy felbontású elektron energia veszteségü spektroszkópiával $300 \mathrm{~K}$ alatt, ami feltételezhetően a hangyasav disszociatív adszorpciójából származik Rh-on, de a képződött formiát instabil és gyorsan bomlott. Ennek eredményeként CO képződött, ami a Rh-hoz kapcsolódott, intenzív abszorpciós sávokat adva $2030 \mathrm{~cm}^{-1}$-nél a Rhx-CO-nak megfelelően. Ez a leírás nagy valószínüséggel érvényes más hangyasav és egyéb hordozós Pt fém kölcsönhatására is.

A helyzet a hordozós aranyon ettől némileg eltér, viszont intenzív formiát sávokat azonosítottunk az FTIR $\mathrm{Au} / \mathrm{SiO}_{2}$ spektrumaiban (27. ábra), ami azt sugallja, hogy a formiát az arany részecskékhez kötődik. A formiát spektrális jellemzője $\mathrm{Au} / \mathrm{SiO}_{2}-\mathrm{n}$ csak $573 \mathrm{~K}$ felett tünik el, jelezve a formiát nagyobb stabilitását az Au-on a Rh-hoz képest. Ennek fényében helyes az a feltételezés, hogy az Au-formiát felületi komplex más oxid hordozókon is megjelenik. Habár ezeknek a koncentrációja összehasonlíthatatlan azokkal a csoportokkal, amelyek a nagy felületű oxidokhoz kötődtek. Ezt a következtetést megerősítettük a TPD eredményeinkkel is (28. ábra). Csak kis mennyiségű bomlástermék deszorpcióját figyeltünk meg az $\mathrm{Au} / \mathrm{SiO}_{2}$-n összhangban a kis formiát koncentrációval az arany felületén. Ezzel ellentétben az $\mathrm{Au} / \mathrm{CeO}_{2}$-ról és $\mathrm{CeO}_{2}$ mintákról nagyobb mennyiségü $\mathrm{H}_{2}, \mathrm{CO}$ és $\mathrm{CO}_{2}$ szabadult fel, amit az oxidokon történő formiát bomlása eredményezett.

A hangyasav bomlása népszerű modellreakció volt az 1950-1960-as években a fémek $^{73,74}$, oxidok ${ }^{75,76}$ és a hordozós fémek ${ }^{73,74,77,78}$ elektromos szerkezeteinek szerepének tanulmányozására. A kutatások során a méréseinkekkel összhangban azokat a katalizátorokat találták aktívnak, amelyek képesek voltak elektront befogadni a hangyasavtól vagy annak a bomlástermékeitöl ${ }^{73-78}$. A hordozós fémekre kapott eredményekböl kiderült, hogy az elektronok Fermi szintjeinek variációja az n-típusú $\mathrm{TiO}_{2}$ hordozóban befolyásolta a hangyasav bomlásában mért aktiválási energiákat $\mathrm{Ni}-\mathrm{en}^{77}$. Ez magyarázható a Ni és az ntipusú $\mathrm{TiO}_{2}$ elektromos kölcsönhatásával.

A TOF vonatkozásában a $\mathrm{Rh} / \mathrm{TiO}_{2}$ mutatta a legmagasabb aktivitást a hordozós $\mathrm{Rh}$ minták között. Később több hangsúlyt fektettek a katalizátor felületén lévő formiát képződésére és stabilitására $^{73,74,137-141}$. Legjobb katalizátoroknak azok a fémek tekinthetők, amelyek könnyen 
képeznek felületi komplexet, de nem magas a stabilitásuk. A bomlási sebesség egy adott hőmérsékleten a formiát képződéshőjének függvényében vulkán-görbét $\operatorname{adott}^{138,139}$. A legésszerübb kapcsolatot Barteau ${ }^{140,141}$ mutatta be, aki egy lineáris összefüggést talált a formiát bomlási hőmérséklete fémeken és a megfelelő fém oxidok képződéshője között. Az aranyat a kevésbé aktív fémek közé sorolták be. Ez összefüggésben van azzal, hogy az Au kis affinitást mutat a $\mathrm{H}_{2}$ atomok irányában, ami meg kell jelenjen a hangyasav bomlásában és a formiát C-H kötésének hasadásában.

Ez az összefüggés azonban a fém egykristály felületen kapott eredményekre alapult. Az elmúlt évtizedekben merült fel, hogy a nanoméretü Au meglepően magas katalitikus aktivitást mutat a fö reakciókban, beleértve a $\mathrm{H}_{2}$ termelő alkoholok és dimetil-éter bomlásait. Ez a helyzet a hangyasav bomlásánál is. A hordozós Au nanorészecskék teljesítménye összehasonlítható a hordozott $\mathrm{Rh}_{\text {-éval }}{ }^{5}$. A legaktívabb katalizátoron, az $\mathrm{Au} / \mathrm{SiO}_{2}-\mathrm{n}$ a reakció elindult még $373 \mathrm{~K}$-en vagy közel e hőmérséklet felett és a teljes konverziót $523 \mathrm{~K}$-en érte el (29.A ábra). Az eredmények további értelmezésében azt is figyelembe kell venni, hogy két reakció út között lehet különbséget tenni a hangyasav bomlásánál

$$
\begin{array}{ll}
\mathrm{HCOOH}=\mathrm{H}_{2}+\mathrm{CO}_{2} & \Delta \mathrm{G}=-48,4 \mathrm{~kJ} / \mathrm{mol} \\
\mathrm{HCOOH}=\mathrm{H}_{2} \mathrm{O}+\mathrm{CO} & \Delta \mathrm{G}=-28,5 \mathrm{~kJ} / \mathrm{mol}
\end{array}
$$

A 29.B ábrán látszik, hogy a bomlás iránya $\mathrm{Au} / \mathrm{SiO}_{2}, \mathrm{Au} /$ norit és $\mathrm{Au} / \mathrm{CeO}_{2}$ majdnem kizárólag a dehidrogéneződési reakciót katalizálják, különösen alacsonyabb hőmérsékleten. Magasabb hőmérsékleteken és konverzióknál viszont a $\mathrm{H}_{2}$ szelektivitás lecsökken az alkalmazott katalizátortól függő mértékben. A többi Au katalizátoron a dehidratációs reakció volt a fö folyamat (31. egyenlet). Fontos rámutatni, hogy nem vagy csak nagyon kis változás történt az aktivitásban és a szelektivitásban még több óra elteltével is. Lehetséges ok a dezaktiválódás hiányára, hogy a $\mathrm{CO}$ nem bomlik az $\mathrm{Au}$ katalizátoron felületi szenet eredményezve.

Az in situ IR tanulmányokból kiderült, hogy átmeneti formiát képződés történik a reakció alatt 383-523 $\mathrm{K}$ között, még $\mathrm{Au} / \mathrm{SiO}_{2}-\mathrm{n}$ is, ahol a formiát kizárólag az $\mathrm{Au}$ részecskékhez kötődött. Ez azt sugallja, hasonlóképp korábbi tanulmányokhoz ${ }^{79-83}$, hogy a hangyasav bomlása formiát képződésen és bomláson keresztül játszódik le. A hangyasav bomlására a következő elemi lépéseket javasoljuk: 
$\operatorname{HCOOH}_{(\mathrm{g})}=\mathrm{HCOOH}_{(\mathrm{a})}$

$\operatorname{HCOOH}_{(\mathbf{a})}=\mathrm{H}_{(\mathbf{a})}+\mathrm{HCOO}_{(\mathbf{a})}$

$\mathrm{HCOO}_{(\mathbf{a})}=\mathrm{CO}_{2(\mathbf{a})}+\mathrm{H}_{(\mathbf{a})}$

$\mathrm{CO}_{2(\mathrm{a})}=\mathrm{CO}_{2(\mathrm{~g})}$

$2 \mathbf{H}_{(\mathbf{a})}=\mathbf{H}_{2(\mathrm{~g})}$

Nagy valószínűséggel a lassú lépés az adszorbeálódott formiát C-H kötésének hasadása.

A TOF értékeket összehasonlítva az $\mathrm{Au}$ mintákon (8. táblázat), a legmagasabb számított fajlagos aktivitást a dehidrogénezési reakcióban a hordozott Au katalizátorok közül a $\mathrm{SiO}_{2}$-ra és a noritra kaptuk. Az látszik, hogy az Au nanorészecskék mérete nem játszik nagy szerepet a mérések során alkalmazott arany nanorészecskék méretének intervallummán belül. Ha jelentős volt a hangyasav adszorpciója és reakciója az adott oxid hordozón, akkor a dehidrogéneződési reakció sebessége és a hidrogénképződés szelektivitása csökkent.

Egy érdekes jellemzője a hangyasav bomlásának ezeken az Au katalizátorokon, hogy a hangyasavhoz CO-t adva nem vagy csak nagyon kis mértékben befolyásolja a bomlás sebességét és irányát. Ez ellentétben áll a Rh katalizátorokra kapott eredményekkel, ahol a bomlást csaknem teljesen megállítja a CO jelenléte 5 . FTIR spektroszkópiás mérésekből kiderült, hogy a bomlás során képződött $\mathrm{CO}$ erősen kötődött a Rh-hoz és ezáltal lecsökkenti a $\mathrm{HCOOH}$ disszociatív adszorpciója számára a szabad Rh helyeket. A CO az Au részecskéken gyengén adszorbeálódik $300 \mathrm{~K}$-en és e felett, így nem meglepő, hogy nem volt megfigyelhető dezaktiválódás még $\mathrm{Au} / \mathrm{Al}_{2} \mathrm{O}_{3}$-on sem, habár tekintélyes mennyiségü $\mathrm{CO}$ képződik a bomlásban ezeken a katalizátorokon.

Ezen munka elsődleges célja is a CO-mentes $\mathrm{H}_{2}$ előállítása volt, nagy erőfeszítést tettünk, hogy fokozzuk a $\mathrm{H}_{2}$ szelektivitást és a yieldet. A hangyasavhoz víz hozzáadásával eltávolítottuk a kis mennyiségben képződött CO-t az Au/SiO${ }_{2}-n 473 \mathrm{~K}$-en, Au/noriton 383$423 \mathrm{~K}$ között és $\mathrm{Au} / \mathrm{CeO}_{2}$ esetén 383-523 K-en. Nagyon valószínü, hogy ez a víz-gáz reakció következménye:

$\mathrm{CO}+\mathrm{H}_{2} \mathrm{O}=\mathrm{CO}_{2}+\mathrm{H}_{2}$

Más esetekben is tudtuk fokozni kis mértékben a szelektivitást víz jelenlétében, de a 100\%-ot nem érte el. 
Végül összehasonlíthatjuk az eredményeket a korábban kapottakkal. Bár a kísérleti körülmények eltérőek, mégis arra a következtetésre juthatunk, hogy a legaktívabb $\mathrm{Au} / \mathrm{SiO}_{2}$ katalizátor katalitikus aktivitása a bomlásban jobb, mint azok a minták, amiket Ojeda és Bulushev $^{81,82}$ tanulmányban használtak. Ha az $\mathrm{Au} / \mathrm{Al}_{2} \mathrm{O}_{3}$ katalitikus viselkedését hasonlítjuk össze a korábban vizsgáltakkal ${ }^{82}$, arra a megállapításra juthatunk, hogy a mi mintánk kevésbé aktív és szelektív a $\mathrm{H}_{2}$ képződésben. Ez elsősorban a hordozók különböző formáinak és előkezelésének tulajdonítható. Ami a szén hordozós Au és Pt fémek tekintetében jelenik meg, hogy a $\mathrm{H}_{2}$ képződés szelektivitás és yield a hangyasav reformálásában magasabb a Pt fémek ${ }^{83}$ esetében. 


\section{Mérési eredmények bemutatása és értelmezése}

\subsubsection{Főbb konklúziók}

(i) Az FTIR spektroszkópiás mérések $\mathrm{Au} / \mathrm{SiO}_{2}-\mathrm{n}$ bemutatták $300 \mathrm{~K}$-en a hangyasav disszociatív adszorpcióját és az Au-hoz kötött formiát jelenlétét. A formiát formák képződését még $573 \mathrm{~K}$-en is detektáltuk. Az in situ IR tanulmányokból kiderült, hogy a formiát a katalizátor felületén van a katalitikus reakció alatt 383-523 K-en.

(ii) Különbözö hordozós Au katalizátorok esetében azt találtuk, hogy hatékony katalizátorai a hangyasav gőz fázisú bomlásának 373-573 K között.

(iii) A bomlás reakcióútját befolyásolta a hordozó természete. Magas szelektivitás értéket kaptunk 90-100\% $\mathrm{Au} / \mathrm{SiO}_{2}-\mathrm{n}, \mathrm{Au} /$ noriton és $\mathrm{Au} / \mathrm{CeO}_{2}$-on.

(iv) Víz hozzáadása a hangyasavhoz fokozta a $\mathrm{H}_{2}$ yield és a szelektivitás értékeket. 


\section{6. Összefoglalás}

A technológia fejlődésének egyik elengedhetetlen lépése a katalizátorok alkalmazása és azok folyamatos fejlesztése. Pár évtizede az ipari folyamatok fö célja a lehető legmagasabb konverzió elérése volt, míg ma a katalízis legfontosabb feladata a magas szelektivitás; hiszen sok esetben a képződött melléktermékeknek számos negatív hatása lehet mind gazdasági, mind környezetvédelmi szempontokra vonatkozóan. Az a felfedezés, hogy az anyagok a nanoméretü tartományban megváltoztatják a tulajdonságaikat, a katalízis területén is új utat nyitott a kutatók számára. A nanorészecskék kiemelkedő katalitikus tulajdonsága talán az arany esetében a legszembetűnőbb, hiszen míg tömbi fázisban teljesen inertként viselkednek, addig, ha a részecskék a nano mérettartományba esnek, jelentős katalitikus aktivitást mutatnak; különösen, ha a méretük 2-10 nm és valamilyen oxid hordozón vannak impregnálva. Nem kétséges, hogy a 21. század egyik kihívása a hordozós, azonos méretü, jól szabályozható fém nanorészecskéket tartalmazó katalizátorok előállítása, jellemzése és katalitikus tulajdonságaik megismerése.

Célunk tehát ezen arany nanorészecskéket tartalmazó katalizátorok viselkedésének megismerése a hidrogéntermelő reakciókban. Ehhez olyan kiindulási anyagokat választottunk, amelyekben a $\mathrm{C} / \mathrm{H}$ arány alacsony, mivel így nagyobb szelektivitást érhetünk el. Fontos szempont volt a reaktánsok kiválasztásánál még, hogy nagy mennyiségben rendelkezésre álljon vagy olcsó legyen az elöállítása illetve a környezetre gyakorolt hatása ne legyen káros. Így a legfontosabb vegyületek, amelyek ezen szempontoknak megfelelnek a hangyasav, metanol, etanol és a dimetil-éter. A hidrogén szelektivitás növelésének érdekében minden esetben arany katalizátort alkalmaztunk különbözö hordozókra impregnálva. Köztudott, hogy a hidrogén mellett melléktermékként képződött CO nagymértékben lemérgezi az alkalmazott katalizátort már nyomnyi mennyiségben is, a katalizátor fém részecskéihez való adszorpciójával. Ez a tény nagy nehézséget okoz jelenleg is a katalízis kémia területén. Viszont már régebbi vizsgálatok is bizonyították, hogy az arany igen jól oxidálja a CO-t már szobahőmérséklet alatt is. Ezen tények összessége vezetett ahhoz az elképzeléshez, hogy arany nanorészecskék oxidhordozóra való diszpergálásával olyan katalizátort kaphatunk, amelynek segítségével CO mentes hidrogént állíthatunk elő.

Célunk a nanoméretű arany katalitikus vizsgálata volt termikus körülmények között $\mathrm{CeO}_{2}, \mathrm{Al}_{2} \mathrm{O}_{3}, \mathrm{MgO}, \mathrm{TiO}_{2}, \mathrm{SiO}_{2}, \mathrm{ZSM}-5$ valamint norit hordozókon a metanol, etanol, 
hangyasav valamint a dimetil-éter bomlásánál, a konverzió és a szelektivitás növelésének lehetőségeinek feltérképezésével.

Az arany katalizátorokat minden esetben impregnálással állítottuk elö, a hordozókra felvitt arany mennyisége 1 és 5\% között volt. Ehhez hidrogén-tetrakloroaurát $\left(\mathrm{HAuCl}_{4} * 3\right.$ $\mathrm{H}_{2} \mathrm{O}$ ) vizes oldatát használtunk. A termikus mérések előtt az így előállított katalizátorokat 573 K-en 30 percet oxidáltuk és $673 \mathrm{~K}$-en 60 percet redukáltuk in situ, $40 \mathrm{ml} / \mathrm{min}$-es gázáramban. A norit hordozót a katalizátor előállítás előtt előkezeltük, 12 órán keresztül 10 w/w\%-os sósav oldattal tisztítottuk, majd kloridmentesre mostuk.

A hordozók felületére impregnált arany részecskék méretét transzmissziós elektron mikroszkópiás (TEM) módszerrel határoztuk meg.

A katalizátorok felületén lévő arany részecskék a reakciók alatti oxidációs állapotának változásának követése céljából röntgenfotoelektron spektroszkópiás (XPS) vizsgálatokat készítettünk. Az oxidált arany minták spektrumának mennyiségi elemzése kimutatta, hogy az $\mathrm{Au}^{3+}$ mellett az arany egy része $\mathrm{Au}^{1+}$ állapotban van. A katalizátor $673 \mathrm{~K}$-es redukciója az $\mathrm{Au}^{3+}$ és $\mathrm{az} \mathrm{Au}^{1+} \mathrm{Au}^{0}$-vá alakulásához vezetett, viszont $\mathrm{az} \mathrm{Au}^{1+}$ nem tünt el teljesen. Ennek valószínủ oka lehet, hogy az arany nanorészecskékben az $\mathrm{Au}^{1+}$-at stabilizálja az oxid hordozó. Az a tény, hogy a $\mathrm{Ce}^{3+}$ kötési energiái már akkor megjelentek, amikor az arany a hordozóra került, azt feltételezi, hogy az arany és $\mathrm{CeO}_{2}$ közötti erös kölcsönhatás a $\mathrm{Ce}^{4+}$ részleges redukcióját okozza. Hasonló jelenséget tapasztaltunk amikor néhány Pt fémet adszorbeáltattunk $\mathrm{CeO}_{2}$ felületen.

Infravörös (IR) spektrométerrel a katalizátorok felületén kialakult felületi vegyületeket mutattuk ki, egyrészt az adszorpciót követően szívatás közben a hőmérséklet növelésével, másrészt a reaktáns + víz keverék reformálási reakció során magas hőmérsékleten illetve bevilágítás hatására.

Az alkalmazott kiindulási vegyületek bomlási és reformálási reakcióinak lejátszódását, a termékek képződését és ezek mennyiségét minden esetben HP 5890 Series II. típusú gázkromatográffal követtük. A különböző vegyületeket PORAPAK Q és PORAPAK S kolonnák segítségével választottuk el és hővezetőképességi (TC) valamint lángionozációs (FID) detektorokkal analizáltuk.

A katalizátorok pontosabb jellemzésének és a reakciók lejátszódása alatti viselkedésüknek megértése érdekében hőmérsékletprogramozott deszorpciós (TPD) valamint hőmérsékletprogramozott redukciós (TPR) méréseket végeztünk. Az alkalmazott körülmények között általunk legaktívabbnak talált katalizátorok esetében meghatároztuk a reakció rendűségét és az aktiválási energiákat is. 
A metanol infravörös spektroszkópiás vizsgálata kimutatta, hogy a metanol disszociációja 300 K-en föleg metoxi-csoportok képződésével történik az oxid hordozókon. Az arany jelenlétének következtében a deszorbeálódott termékek mennyisége növekedett. A bomlási reakció iránya és a katalizátor aktivitása érzékenyen függött a hordozó természetétől. A hidrogén képződést tekintve a legaktívabb katalizátor az $\mathrm{Au} / \mathrm{CeO}_{2}$ volt, ezt követte a $\mathrm{Au} / \mathrm{MgO}, \mathrm{Au} / \mathrm{TiO}_{2}$ és az $\mathrm{Au} / \mathrm{Norit}$. Ezzel szemben az $\mathrm{Au} / \mathrm{Al}_{2} \mathrm{O}_{3}$-on a legfontosabb folyamat a dehidratációs reakció volt, ami dimetil-étert eredményezett. $\mathrm{Au} / \mathrm{CeO}_{2}$-on a metanol bomlása $500 \mathrm{~K}$ körül indult és 723-773 K-en közelíti meg a teljes konverziót. A képződött termékek $\mathrm{H}_{2}(68 \%), \mathrm{CO}(27 \%)$ valamint nagyon alacsony mennyiségü metán és $\mathrm{CO}_{2}$. A metanol bomlása első rendü kinetikát követett. Ennek a folyamatnak az aktiválási energiája $87 \mathrm{~kJ} / \mathrm{mol}$. A $\mathrm{H}_{2}$ képződés szelektivitása 573-773 K között 90\% volt, ez az érték 97\%-ra növekedett a metanol:víz (1:1) reakcióelegyet használva, jelezvén a víz részvételét a reakcióban. $\mathrm{Az} \mathrm{Au}$ katalizátorok dezaktiválódása nem volt tapasztalható még 773 K-en 10 óra alatt sem. Munkánk során arra a következtetésre jutottunk, hogy az arany és a részben redukálódott cérium-dioxid közötti határfelület a felelős az $\mathrm{Au} / \mathrm{CeO}_{2}$ katalizátorok magas aktivitásáért.

Az etanol esetében az infravörös spektroszkópiás tanulmányok kimutatták, hogy az etanol disszociációja etoxi-csoportok képződésével jár 300 K-en valamennyi oxid hordozón. $\mathrm{Az} \mathrm{Au}$ szerepe nyilvánvalóan látszik az etoxi-csoportok képződésének növekedésében $\mathrm{Au} / \mathrm{SiO}_{2}$-n és a deszorbeálódott termékek mennyiségének a növekedésében a TPD spektrumok alapján. A hordozós Au részecskék többnyire az etanol dehidrogénezését katalizálják, amely hidrogén és acetaldehid termékeket ad. Egy kivétel van az $\mathrm{Au} / \mathrm{Al}_{2} \mathrm{O}_{3}$, ahol a fö folyamat a dehidratáció, ez etilént és dimetil-étert eredményezve fö termékként. A C-C kötés hasadás csak korlátozott mértékben történik meg az összes vizsgálat mintán. A hidrogén képződését illetően a legaktívabb katalizátor az $\mathrm{Au} / \mathrm{CeO}_{2}$, ezt követi az $\mathrm{Au} / \mathrm{SiO}_{2}, \mathrm{Au} /$ norit, $\mathrm{Au} / \mathrm{TiO}_{2}$ és az $\mathrm{Au} / \mathrm{MgO}$. Az elsődleges folyamatban kialakult acetaldehid $\mathrm{Au} / \mathrm{CeO}_{2}-\mathrm{on}$ átalakul $623 \mathrm{~K}$ körül 2-pentanonná és 3-pentén-2-onná. Az etanol bomlása $\mathrm{Au} / \mathrm{CeO}_{2}$-on első rendủ kinetikát követett. Ennek a folyamatnak az aktiválási energiája $57,0 \mathrm{~kJ} / \mathrm{mol}$. Az $\mathrm{Au} / \mathrm{CeO}_{2}$ nem dezaktiválódott a vizsgált 8 óra alatt még $623 \mathrm{~K}$-en sem.

A dimetil-éter (DME) adszorpcióját és reakcióját vizsgálva az arany nanorészecskéket tartalmazó különböző oxid hordozókon illetve szén noriton az infravörös spektroszkópiás tanulmányok és a hőmérséklet programozott deszorpciós mérések során kiderült, hogy a DME a legszívesebben az oxid hordozókon adszorbeál. Megállapítottuk, hogy a dimetil-éter korlátozottan disszociál metoxi csoporttá arany nanorészecskéken. A hidrogén képződés 
szempontjából a leghatékonyabb katalizátor ebben az esetben is az $\mathrm{Au} / \mathrm{CeO}_{2}$ volt. $\mathrm{Au} / \mathrm{Al}_{2} \mathrm{O}_{3}$ katalizátoron a fő folyamat a metanol képződés volt nagyon kevés hidrogén tartalommal. A $\mathrm{CeO}_{2}-\mathrm{Al}_{2} \mathrm{O}_{3}$ vegyes oxidon lévő $\mathrm{Au}$ eredményezte a legaktívabb katalizátort a hidrogénképződés szempontjából. A DME reformálásánál a hidrogén kitermelés megközelítette a 73\%-ot 723 - $773 \mathrm{~K}$ között. Ezt a jelleget magyarázza a DME metanollá történő hidrolízise alumínium-oxidon és ennek a gyors tovább bomlása az $\mathrm{Au} / \mathrm{CeO}_{2}$ határfelületen. Kálium promótert adva az $\mathrm{Au} / \mathrm{CeO}_{2}-\mathrm{Al}_{2} \mathrm{O}_{3}$ katalizátorhoz tovább fokozza a hidrogén képződést, ezt jelzi a hozam 87\%-ig történő növekedése. Nem tapasztaltuk a katalizátor dezaktiválódását 773 K-en 10 órát követve a reakciót.

A hangyasav gőzfázisú bomlását tanulmányozva, különböző hordozós arany katalizátorokon $\mathrm{CO}$ mentes hidrogén termelés céljából, a bomlás és a hidrogén képződés tekintetében az $\mathrm{Au} / \mathrm{SiO}_{2}$ katalizátort találtuk a legaktívabbnak, az eddigi vizsgálatainktól eltérően, amelyek esetében, kivétel nélkül az arany-cérium-dioxid volt a legkiemelkedőbb katalizátor. A reakció $373 \mathrm{~K}$-en indult be és $523 \mathrm{~K}$-en vált teljessé. A hordozó természetétől

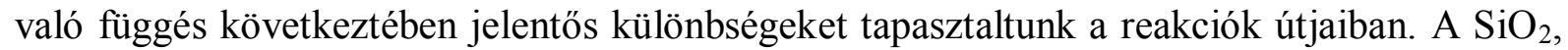
$\mathrm{CeO}_{2}$ és szén Norit hordozós Au katalizátorokon a dehidrogénezési reakció volt túlsúlyban, míg $\mathrm{Al}_{2} \mathrm{O}_{3}, Z \mathrm{ZSM}-5$ és $\mathrm{TiO}_{2}$ hordozós $\mathrm{Au}$ katalizátorok a hangyasav dehidratációjának kedveztek. Tiszta, $\mathrm{CO}$ mentes hidrogént kaptunk $\mathrm{Au} / \mathrm{SiO}_{2}$ és $\mathrm{Au} / \mathrm{CeO}_{2}$ katalizátorokon $473 \mathrm{~K}$ alatt. Nem történt változás sem a szelektivitásban, sem az aktivitásban 10 órán keresztül figyelve a reakciót. A legtöbb katalizátor esetében a szelektivitás javult a hangyasavhoz történő víz hozzáadása által. In situ infravörös spektroszkópiás tanulmányok során kiderült, hogy az $\mathrm{Au} / \mathrm{SiO}_{2}$-n képződő formiát kizárólag az $\mathrm{Au}$ részecskéken találhatóak. A $\mathrm{HCOOH}$ bomlása $\mathrm{Au} / \mathrm{SiO}_{2}$-on nullad rendü kinetikát követett. A bomlás aktiválási energiája 60,7 $\mathrm{kJ} / \mathrm{mol}$, a hidrogénképződésé pedig $58,5 \mathrm{~kJ} / \mathrm{mol}$ volt.

Munkánkat összefoglalva elmondható, hogy a vizsgált kiindulási anyagok bomlásának hatékony katalizátorai az oxid hordozóra felvitt arany nanorészecskék. Általánosan elmondható, hogy a reakciók iránya nagymértékben függött az alkalmazott hordozó természetétől. A legtöbb esetben a $\mathrm{CeO}_{2}$ hordozós katalizátorok bizonyultak a legaktívabbaknak a hidrogén szelektivitás és a konverzió szempontjából, míg a legkevésbé aktívnak a szilícium-dioxid hordozós katalizátorok bizonyultak. $\mathrm{Al}_{2} \mathrm{O}_{3}$-at alkalmazva a nanorészecskék hordozójaként a dehidratációs reakció volt túlsúlyban valamennyi kiindulási anyag bomlásakor. A metanol, dimetil-éter adszorpciója első lépésként metoxi csoportot eredményezett, az etanol etoxi csoportot, míg a hangyasav formiát megjelenése közben adszorbeált a felületen. Az XPS mérésekből kiderült, hogy 673 K-en redukálva a 
katalizátorokat túlnyomó többségben az arany nanorészecskék $\mathrm{Au}^{0}$ oxidációs állapotban voltak, de kis mennyiségben $\mathrm{Au}^{+}-\mathrm{t}$ is tartalmaztak.

A reakcióhoz vizet adva a lejátszódó víz-gáz reakció minden esetben a hidrogén képződés növekedését eredményezte. 


\section{Summary}

Using catalytic converters and developing them continuously is an essential step in the development of technology. A few decades ago the main goal of industrial processes was to reach the highest possible conversion, while today the most important task of catalysis is the high selectivity because in lot of cases produced waste products can have several negative economic and environmental effects. The discovery that elements change their characteristics in nano-scale range opened new ways for researchers in the field of catalysis. The outstanding catalytic characteristic on nanoparticles is the most striking in case of gold. They behave totally inert in bulk phase, but when the particles fall into nano size range they show significant catalytic activity; especially if their size is $2-10 \mathrm{~nm}$ range and they are impregnated on oxide supports. Undoubtedly, one of the challenges of the 21 st century is creating and describing catalysts consisting of supported metal nanoparticles of a uniform size that can be controlled and influence their catalytic behaviour.

Our aim was investigate and describe the catalytic behavior of these supported golden nanoparticles in the hydrogen producing reactions. Such input materials were chosen in which the $\mathrm{C} / \mathrm{H}$ ratio is low, so greater selectivity can be gained in this way. Other important viewpoints were considered when selecting reactants: should be available in sufficient quantity, cheap and they should not be harmful to the environment. So the most important compounds that comply with these conditions were formic acid, methanol, ethanol and dimethyl-ether. In order to increase hydrogen selectivity gold impregnated catalysts on different supports were used in every case. It is widely known that formed $\mathrm{CO}$ as co-product besides hydrogen is poisoning the applied catalyst even in trace amounts by its adsorption to the metal particles of the catalyst. This fact causes difficulties in the field of catalysis chemistry. However, previous experiments were already proved that gold oxidizing CO very effectively even at room temperature. All of these facts led to the conception that the help of these prepared $\mathrm{Au}$ gold nanoparticles supported catalyst was able to produced $\mathrm{CO}$-free hydrogen. During my work the catalytic decomposition of methanol, ethanol, formic acid and dimethyl-ether were investigated on nanosize $\mathrm{Au}$ supported $\mathrm{CeO}_{2}, \mathrm{Al}_{2} \mathrm{O}_{3}, \mathrm{MgO}, \mathrm{TiO}_{2}, \mathrm{SiO}_{2}$, ZSM-5 and norit catalysts and identifying the possibilities to increase conversion and selectivity as highest as possible.

Gold catalysts were prepared by impregnation in every case, the applied gold content of the catalysts was between 1 and $5 \mathrm{w} / \mathrm{w} \%$. Hydrogen-tetrachloroaura $\left(\mathrm{HAuCl}_{4} * 3 \mathrm{H}_{2} \mathrm{O}\right)$ was 
used as stock solution. Before catalytic measurements the prepared Au samples were oxidized at $573 \mathrm{~K}$ for 30 minutes and were also reduced in-situ at $673 \mathrm{~K}$ for 60 minutes in $40 \mathrm{ml} / \mathrm{min}$ gas flow. The norit support was pretreated before the catalyst was prepared, it was cleaned in $10 \mathrm{w} / \mathrm{w} \%$ hydrochloric acid solution for 12 hours, then it was washed with miliQ water until it was free of chloride.

The size of the impregnated gold nanoparticle was determined by transmission electron microscopy (TEM) method.

In order to determinate the change of the oxidation state of the gold particles during the reactions on the surface of catalysts X-ray photoelectron spectroscopy (XPS) measurements were made. Quantitative evaluation of the XPS spectra for oxidized Au samples showed that besides $\mathrm{Au}^{3+}$ a fraction of $\mathrm{Au}$ is in the $\mathrm{Au}^{1+}$ state. Reduction of $\mathrm{Au}$ catalyst at $673 \mathrm{~K}$ led to the transformation of $\mathrm{Au}^{3+}$ and $\mathrm{Au}^{1+}$ to $\mathrm{Au}^{0}$, but the complete elimination of $\mathrm{Au}^{1+}$ was not achieved. The possible reason is that $\mathrm{Au}^{1+}$ in the $\mathrm{Au}$ nanoparticles is stabilized by the supports. The fact that the $\mathrm{BE}$ values of $\mathrm{Ce}^{3+}$ already appeared, when $\mathrm{Au}$ was deposited onto $\mathrm{CeO}_{2}$ suggests a strong interaction between $\mathrm{Au}$ and $\mathrm{CeO}_{2}$ resulting in the partial reduction of $\mathrm{Ce}^{4+}$. Similar phenomenon was experienced following the deposition of some Pt metals on $\mathrm{CeO}_{2}$.

The surface species formed during the decomposition were studied by infrared (IR) spectroscopy. Two types of experiments were performed: increasing the temperature after adsorption, on the other hand the reformation reaction of reactant + water was followed on high temperature and effect of illumination was also studied.

The decomposition and reaction of the applied compounds and amount of products were identified by HP 5890 Series II. gas chromatograph in every case. The different compounds were separated with the help of PORAPAK Q and PORAPAK S columns and they were analyzed by thermal conductivity (TC) and fame ionization (FID) detectors.

The catalysts were characterized by thermal programmed desorption (TPD) and thermal programmed reduction (TPR) measurements to prescribe and understand better catalytic behaviour. In the case of most active catalysts under the applied circumstances the reaction order of the reaction and the activation energy were identified.

In the case of catalytic decomposition of methanol the infrared spectroscopic examination revealed the dissociation of methanol at $300 \mathrm{~K}$ led to the formation of methoxy groups on oxide surfaces. As a result of the presence of gold the amount of products desorbed increased. The direction of the decomposing reaction and the activity of the catalyst sensitively depended on the nature of the applied supports. Considering hydrogen formation 
the most active catalyst was $\mathrm{Au} / \mathrm{CeO}_{2}$, it was followed by $\mathrm{Au} / \mathrm{MgO}, \mathrm{Au} / \mathrm{TiO}_{2}$ and $\mathrm{Au} / \mathrm{Norit}$. On the contrary, the most important process on $\mathrm{Au} / \mathrm{Al}_{2} \mathrm{O}_{3}$ was the dehydration reaction, which resulted in dimethyl-ether. The decomposition of methanol on $\mathrm{Au} / \mathrm{CeO}_{2}$ started around $500 \mathrm{~K}$ and it approaches the complete conversion at 723-773 K. The created products are $\mathrm{H}_{2}(68 \%)$, $\mathrm{CO}(27 \%)$, very low amount of methane and $\mathrm{CO}_{2}$. The decay of methane showed first order kinetics. The determined activation energy of this process was $87 \mathrm{~kJ} / \mathrm{mol}$. The selectivity of $\mathrm{H}_{2}$ was $90 \%$ between 573 and $773 \mathrm{~K}$, this value increased to $97 \%$ by using reaction mix of methanol : water $(1: 1)$ indicating the presence of water in the reaction. The deactivation of $\mathrm{Au}$ catalysts was not experienced even at $773 \mathrm{~K}$ after 10 hours. During our work we were concluded that the interface of gold and the partially reduced cerium-dioxide was responsible for the high activity of $\mathrm{Au} / \mathrm{CeO}_{2}$ catalysts.

In case of ethanol the infrared spectroscopic studies showed that the dissociation of ethanol led to the formation of ethoxy groups at $300 \mathrm{~K}$ on all oxide supportss. The role of $\mathrm{Au}$ was clearly seen in the growth of the formation of ethoxy groups on $\mathrm{Au} / \mathrm{SiO}_{2}$ and in the growth of the amount of desorbed products as proved by the TPD spectra. The deposited Au particles were mostly catalysed the dehydrogenation of ethanol, which gives hydrogen and acetaldehyde. $\mathrm{Au} / \mathrm{Al}_{2} \mathrm{O}_{3}$ is the one exception where the dehydration as the main process was resulted in ethylene and dimethyl-ether as main products. The $\mathrm{C}-\mathrm{C}$ bond cleavage takes place in a limited way on all the examined samples. Considering hydrogen formation the most active catalyst was $\mathrm{Au} / \mathrm{CeO}_{2}$, it was followed by $\mathrm{Au} / \mathrm{SiO}_{2}, \mathrm{Au} /$ norit, $\mathrm{Au} / \mathrm{TiO}_{2}$ and $\mathrm{Au} / \mathrm{MgO}$. The acetaldehyde formed in the primary process and it was transformed to 2-pentanone and 3penten-2-one at $623 \mathrm{~K}$. The decomposition of ethanol on $\mathrm{Au} / \mathrm{CeO}_{2}$ followed first order kinetics. The activation energy of this process was $57.0 \mathrm{~kJ} / \mathrm{mol}$. $\mathrm{Au} / \mathrm{CeO}_{2}$ was not deactivated even at $623 \mathrm{~K}$ during the examination of 10 hours.

The adsorption and reactions of dimethyl-ether (DME) were investigated on $\mathrm{Au}$ nanoparticles supported by various oxides and carbon norit. Infrared spectroscopic and temperature programmed desorption studies revealed that DME adsorbs readily on most oxidic supports. A limited dissociation of DME to methoxy species was established on $\mathrm{Au}$ perticles by IR spectroscopy. As regards the formation of hydrogen, $\mathrm{Au} / \mathrm{CeO}_{2}$ is the most effective catalyst. $\mathrm{On} \mathrm{Au} / \mathrm{Al}_{2} \mathrm{O}_{3}$ catalyst the main process was the formation of methanol with a very small amount of hydrogen. Deposition of $\mathrm{Au} \mathrm{CeO}_{2}+\mathrm{Al}_{2} \mathrm{O}_{3}$ mixed oxide resulted in a very catalyst for $\mathrm{H}_{2}$ production. The yield for $\mathrm{H}_{2}$ in the reforming of DME approached the value of $73 \%$ at $723-773 \mathrm{~K}$. This feature was explained by the hydrolysis of DME to methanol on alumina, and the fast decomposition of methanol at the $\mathrm{Au} / \mathrm{CeO}_{2}$ interface. 
Adding potassium promoter to $\mathrm{Au} / \mathrm{CeO}_{2}+\mathrm{Al}_{2} \mathrm{O}_{3}$ catalyst further enhanced the production of hydrogen as indicated by the increase of the yield to $\sim 87 \%$. No deactivation of the catalyst was experienced at $773 \mathrm{~K}$ for the measured time, $\sim 10 \mathrm{~h}$.

Studying the gas phase decomposition of formic acid on different Au-supported catalysts, in order to create CO-free hydrogen, regarding decomposition and hydrogen formation the catalyst $\mathrm{Au} / \mathrm{SiO}_{2}$ was found the most active, on the contrary to our previous examinations where gold-cerium-dioxide was the most significant catalyst without exception. The reaction started at $373 \mathrm{~K}$ and reached $100 \%$ conversion at $523 \mathrm{~K}$. Significant differences was experienced in the reaction ways due to the dependence on the nature of the support. On $\mathrm{SiO}_{2}, \mathrm{CeO}_{2}$ and carbon norit-supported gold catalyst the dehydrogenation reaction was the predominant, while on $\mathrm{Al}_{2} \mathrm{O}_{3}, Z \mathrm{ZSM}-5$ and $\mathrm{TiO}_{2}$-supported gold catalyst favoured the dehydration of formic acid. Pure CO-free hydrogen was formed on $\mathrm{Au} / \mathrm{SiO}_{2}$ and $\mathrm{Au} / \mathrm{CeO}_{2}$ catalysts under $473 \mathrm{~K}$. Observing the reaction for 10 hours there was no change in either the selectivity or the activity. In case of most catalysts the selectivity improved by adding water to formic acid. Infrared spectroscopic studies prove that formate forming on $\mathrm{Au} / \mathrm{SiO}_{2}$ can exclusively be found on $\mathrm{Au}$ particles. The decomposition of $\mathrm{HCOOH}$ on $\mathrm{Au} / \mathrm{SiO}_{2}$ followed zero order kinetics. The activation energy of decomposition was $60.7 \mathrm{~kJ} / \mathrm{mol}$ and that of hydrogen formation was $58.8 \mathrm{~kJ} / \mathrm{mol}$.

Summarizing, based on the results obtained the deposition of Au nanoparticles on oxid supports was active in the decomposition of the studied compounds. Generally it can be stated that the direction of the reactions considerably depended on the nature of the applied support. In most cases the $\mathrm{CeO}_{2}$-supported catalyst proved to be the most active considering hydrogen selectivity and conversion, while silica-supported seemed to be the less active. Using $\mathrm{Al}_{2} \mathrm{O}_{3}$ as carriers of nanoparticles the dehydration reaction was predominant during the decomposition of all the studied compounds. The absorption of methanol, dimethyl-ether resulted in a methoxy group in the first stage, the ethanol resulted in an ethoxy group, while formic acid absorbed formate appeared on the surface. It turned out from XPS measurements that most $\mathrm{Au}$ nanoparticles were in oxidation state $\mathrm{Au}^{0}$, but they contained a small amount of $\mathrm{Au}^{+}$when the catalysts were reduced at $673 \mathrm{~K}$.

In every case, when adding water to the reaction, the water- gas reaction led to increased hydrogen formation. 
8. Irodalmi hivatkozások

G. C. Bond, (1990) Heterogén katalizis, Müszaki Könyvkiadó Budapest

M. Haruta, (1997) Catalysis Today 36:153

P. Tolmacsov, A. Gazsi, F. Solymosi, (2009) Appl. Catal. A Gen. 362:58

A. Gazsi, P. Tolmacsov, F. Solymosi, (2009) Catal. Lett. 130:386

F. Solymosi, A. Erdőhelyi, (1985) J. Catal. 91:327

R. Barthos, A. Széchenyi, F. Solymosi, (2008) Catal. Lett. 120:161

W. A. Bone, R. V. Wheeler, (1906) Phil. Trans 1:206

W. A. Bone and G. W. Andrew, (1925) Proc. Roy. Soc. A 109:409

R. S. Yolles, B. J. Wood, H. Wise, (1971) J. Catal 21:66

G. C. Bond, (1971) Gold Bull

G. C. Bond, D. T. Thompson, (1999) Catal. Rev.-Sci.Eng. 41:319

M. Haruta, T. Kobayashi, H. Sano, N. Yamada, (1978) Chem. Lett. 2:405.

M. Haruta, (2001) Journal of Catalysis 201:221

G. Sandstede, T. N. Veziroglu, C. Derive, J. Pottier, (1972) Proceedings of the 9th world hydrogen energy conference, Paris, France

A. Haryanto, S. Fernando, N. Murali, S. Adhikari, (2005) Energy Fuels 19:2098

L. F. Brown, (2001) Int. J. Hydrogen Energy 26:381

Muradov N, (2001) Catal Commun 2:89

Marino F, Boveri M, Baronetti G, Laborde M, (2001) Int J Hydrogen Energy 26:665

V. V. Galvita, G. L. Semin, V. D. Belyaev, V. A. Semikolenov, P. Tsiakaras, V. A.

Solyanin, (2001) Appl Catal A Gen 220:123

C. Díagne, H. Idriss, A. Kiennemann, (2002) Catal Commun 3:565

R. Barthos, F. Solymosi, (2007) J Catal 249:289

Á. Koós, R. Barthos, F. Solymosi, (2008) J Phys Chem C 112:2607

Barthos R, Széchenyi A, Koós Á, Solymosi F, (2007) Appl Catal A Gen 327:95

F. Solymosi, R. Barthos, A. Kecskeméti, (2008) Appl Catal A Gen 350:30

G. C. Bond, D. T. Thompson, (1999) Catal Rev Sci Eng 41:319

G. J. Hutchings, (2002) Catal Today 72:11

M. C. Kung, R. J. Davis, H. K. Kung, (2007) J Phys Chem 111:11767

M. S. Chen, D. W. Goodman, (2004) Science 306:525

T. V. W. Jannsses, A. Carlsson, A. Puig-Molina, B. S. Clausen, (2006) J Catal 240:108

V. Aguilar-Guerrero, B. C. Gates, (2008) J Catal 260:351

A. Ueda, M. Haruta, (1999) Gold Bull 32:3

F. Solymosi, T. Bánsági, T. Süli Zakar (2003) Phys Chem 5:4724 
Sci 61:1003 $13: 437$ Today 116:367

F. Boccuzzi, A. Chiorino, M. Manzoli, (2003) J Power Sources 118:304

M. Manzoli, A. Chiorino, F. Boccuzzi, (2005) Appl Catal B Env 57:201

T. V. Choudhary, E. Aksoylu, D. W. Goodman, (2003) Catal. Rev. Sci. Eng. 45:151

R. A. van Santen, A. de Koster, T. Koerts, (1990) Catal. Lett. 7:1

F. Solymosi, Gy. Kutsán, A. Erdőhelyi, (1991) Catal. Lett. 11:149

F. Solymosi, A. Erdőhelyi, J. Cserényi, (1992) Catal. Lett. 16:399

M. Belgued, H. Amariglio, P. Pareja, A. Amariglio, J. Sain-Just, (1992) Catal. Today

T. Koerts, M. J. A. G. Deelen, R. A. van Santen, (1992) J. Catal. 138:101

F. Solymosi, A. Erdőhelyi, J. Cserényi, (1994) J. Catal. 147:272

F. Solymosi, J. Cserényi, (1994) Catal. Today 21:561

A. Erdőhelyi, J. Raskó, T. Kecskés, M. Tóth, M. Dömök, K. Baán, (2006) Catal.

J. Raskó, M. Dömök, K. Baán, A. Erdőhelyi, (2006) Appl. Catal. A: Gen. 299:202

A. C. Basagiannis, P. Panagiotopoulou, X. E. Verykos, (2008) Top. Catal. 51:2

A. S. K. Hashmi, G. J. Hutchings, (2006) Angew. Chem. Int. Ed. 45:7896

J. G. Hardy, M. W. Roberts, (1971) Chem. Commun. 494

M. W. Roberts, T. I. Stewart, (1970) Proceedings of Chemisorption and Catalysis, Institute of Petroleum

P.-Y. Sheng, G. A. Bowmaker, H. Idriss, (2004) Appl. Catal. A: Gen. 261:171

Y. Guan, E. J. M. Hensen, (2009) Appl. Catal. A: Gen. 361:49

A. M. Rouhi, (1995) Chem. Eng. News 73:37

J.-L. Li, X.-G. Zhang, T. Inui, (1996) Appl. Catal. A: Gen. 147:23

T. Fleish, (1997) Stud. Surf. Sci. Catal. 107:117

G. A. Oláh, Á. Molnár, (2003) Hydrocarbon Chemistry, Wiley, New York

A. Kecskeméti, R. Barthos, F. Solymosi, (2008) J. Catal. 258:111

A. Széchenyi, F. Solymosi, (2009) Catal. Lett. 127:13

V. V. Galvita, G. L. Semin, V. D. Belyaev, T. M. Yurieva, V. A. Sobyanin, (2001) Appl. Catal. A: Gen. 216:85

K. Takeishi, H. Suzuki, (2004) Appl. Catal. A: Gen. 260:111 
T. Nishiguchi, K. Oka, T. Matsumoto, H. Kanai, K. Utani, S. Imamura, (2004) Appl. Catal. A: Gen. 301:66

K. Faungnawakij, Y. Tanaka, N. Shimoda, T. Fukunaga, S. Kawashima, R. Kikuchi, K. Eguchi, (2006) Appl. Catal. A: Gen. 304:40

T. Kawabata, H. Matsuoka, T. Shishido, D. Li, Y. Tian, T. Sano, K. Takehira, (2006) Appl. Catal. A: Gen. 308:82

T. A. Semelsberger, K. C. Ott, R. L. Borup, H. L. Greene, (2005) Appl. Catal. B: Environ. 61:281

T. A. Semelsberger, K. C. Ott, R. L. Borup, H. L. Greene, (2005) Appl. Catal. B: Environ. 65:291

K. Faungnawakij, N. Shimoda, T. Fukunaga, R. Kikuchi, K. Eguchi, (2009) Appl. Catal. Environ. 92:341

J. H. Choi, K. J. Jeong, Y. Dong, J. Han, T. H. Lim, J. S. Lee, Y. Sung, (2006) J. Power Sources 163:71

C. Fellay, P. J. Dyson, G. Laurenczy, (2008) Angew. Chem. Int. Ed. 47:3966

G. C. Bond, (1962) Catalysis by Metals; Academic: London

P. Mars, J. J. F. Scholten, P. Zwietering, (1963) Adv. Catal. 14:35

Z. G. Szabó, F. Solymosi, (1960) Acta. Chim. Hung. 25:145

J. M. Trillo, G. Munuera, J. M. Criado, (1972) Catal. Rev. 7:51

Z. G. Szabó, F. Solymosi, (1961) Actes Congr. Int. Catal. 2:1627

F. Solymosi, (1968) Catal. Rev.1:233

Á. Koós, F. Solymosi, (2010) Catal. Lett. 138:23

X. Zhou, Y. Huang, W. Xing, C. Liu, J. Liao, T. Lu, (2008) Chem. Commun. 3540:354

M. Ojeda, E. Iglesia, (2009) Angew. Chem. Int. Ed. 48:4800

D. A. Bulushev, S. Beloshapkin, J. R. H. Ross, (2010) Catal. Today 154:7

F. Solymosi, Á. Koós, N. Liliom, I. Ugrai, (2011) J. Catal 279:213

A. Boddien, F. Gärtner, R. Jackstell, H. Junge, A. Spannenberg, W. Baumann, R.

Ludwig, M. Beller, (2010) Angew. Chem. Int. Ed. 49:8993

C. Fellay, P. J. Dyson, G. Laurenczy, (2008) Angew. Chem. Int. Ed. 47:3966

S. Enthaler, J. von Langermann, T. Schmidt, (2010) Energy Environ. Sci. 3:1207

W. B. Kim, G. J. Rodriguez-Rivera, S. T. Evans, T. Voitl, J. J. Einspahr, P. M.

Voyles, J. A. Dumesic, (2005) J. Catal 235:327 
M. Skoda, M. Cabala, I. Matolínová, K. C. Prince, T. Skála, F. Sutara, K. Veltruská, V. Matolín, (2009) J. Chem. Phys. 130:034703$$
\text { (1) }
$$
$52: 53$

97 F. Boccuzzi, A. Chiorino, M. Manzoli, P. Lu, T. Akita, S. Ichikawa, M. Haruta, (2001) J Catal 202:256

C. Binet, M. Daturi, (2001) Catal Today 70:155

A. Trovarelli, (2002) Catalysis by ceria and related materials. World scientific publishing company, Incorporated, USA

M. A. Bartheau, R. J. Madix, (1982) King DA, Woodruff DP (eds) The chemical physics of solid surface and heterogeneous catalysis. Elsevier, Amsterdam, 95 (fejezet 4)

${ }^{101}$ F. Solymosi, A. Berkó, T. I. Tarnóczi, (1984) Surf Sci 141:533

102 J. Hrbek, R. De Paola, F. M. Hoffmann, (1986) Surf Sci 166:361

103 J. L. Davis, M. A. Barteau, (1987) Surf Sci 187:387

104 F. Solymosi, A. Berkó, Z. Tóth, (1993) Surf Sci 285:197

105 J. Greeley, M. Mavrikakis, (2004) J Am Chem Soc 126:3910

106 R. J. Lewis, J. Zhicheng, N. Winograd, (1989) J Am Chem Soc 111:4605

${ }^{107}$ X. Guo, L. Hanley, J. T. Yates, (1989) J Am Chem Soc 111:3155

108 F. Solymosi, K. Révész, (1991) J Am Chem Soc 113:9145

109 M. Rebholz, N. Kruse, (1991) J Chem Phys 95:7745

${ }^{110}$ M. Morkel, V. V. Kaichev, G. Rupprechter, H.-J. Freund, I. P. Prosvirin, V. I. Bukhtiyarov, (2004) J Phys Chem B 108:12955

${ }^{111}$ M. A. Lazaga, D. T. Wickham, D. H. Parker, G. N. Kastanas, B. E. Koel, (1993) ACS Symp Ser 523:90

112 J. Gong, D. W. Flaherty, R. A. Ojifinni, J. M. White, C. B. Mullins, (2008) J Phys Chem $C$ 112:5501

${ }^{113}$ F. Solymosi, G. Klivényi, (1993) J Electr Spectr 64:499 
J. Raskó, F. Solymosi, (1998) Catal Letts 54:40

115 A. Yee, S. J. Morrison, H. Idriss, (1999) J. Catal. 186:279

116 A. Yee, S. J. Morrison, H. Idriss, (2000) Catal. Today 63:327

117 M. A. Natal-Santiago, J. A. Dumesic, (1998) J. Catal. 175:252

118 A. P. Farkas, F. Solymosi, (2008) Surf. Sci. 602:1475

119 B. A. Sexton, (1979) Surf. Sci. 88:299

${ }^{120}$ Q. Dai, A. J. Gellman, (1991) Surf. Sci. 257:103

121 D. M. A. Barteau, (1990) Surf. Sci. 235:235

122 J. Gong, B. Mullins, (2008) J. Am. Chem. Soc. 130:16458

123 S. Strbac, M. A. Ivic, (2009) Electrochim. Acta 54:5408

${ }^{124}$ H. Idriss, C. Diagne, J. P. Hindermann, A. Kiennemann, M. A. Barteau, (1995) J. Catal. 155:219

125 P.-Y. Sheng, A. Yee, G. A. Bowmaker, H. Idriss, (2002) J. Catal. 208:393

${ }^{126}$ H. Madhavaram, H. Idriss, (2004) J. Catal. 224:358

${ }^{127}$ L. Bugyi, A. Oszkó, F. Solymosi, (1996) J. Catal. 159:305

${ }^{128}$ F. Solymosi, L. Bugyi, A. Oszkó, (1996) Langmuir 12:4145

129 H. Song, U. S. Ozkan, (2009) J. Catal. 261:66

130 H. Song, B. Tan, U. S. Ozkan, (2009) Catal. Lett. 132:422

${ }^{131}$ T. P. Bebe, J. E. Crowell, J. T. Yates, (1988) J. Phys. Chem. 92:1296

132 J. G. Chen, P. Basu, T. H. Ballinger, J. T. Yates, (1989) Langmuir 5:352

133 Á. Koós, R. Barthos, F. Solymosi, (208) J. Phys. Chem. C 112:2607

134 L. Bugyi, F. Solymosi, (1997) Surf. Sci. 385:365

135 M. P. Kiskinova, (1991) Stud. Surf. Sci. Catal. 70:1

136 T. Kecskés, J. Raskó, J. Kiss, (2004) Appl. Catal. A 268:9

137 R. E. Eischens, W. A. Pliskin, (1961) Actes Congr. Int. Catal. 2:789

${ }^{138}$ W. M. H. Sachtler, J. Fahrenfort, (1961) Actes Congr. Int. Catal. 2:831

139 R. J. Madix, (1980) Adv. Catal. 29:1

${ }^{140}$ M. A. Barteau, (1991) Catal. Lett. 8:175

${ }^{141}$ M. Mavrikakis, M. A. Barteau, (1998) J. Mol. Catal. A: Chem. 131:135 


\section{Publikációs lista}

A Ph.D. értekezés alapjául szolgáló publikációk

Hydrogen Formation in the Reactions of Methanol on Supported Au Catalysts

Gazsi, A.; Bansagi, T.; Solymosi, F.

Catal Lett. 131 (2009) 33.

MTMT azonosító: 113805

IF.: 2,021

Független hiv.: 13

Függő hiv.: 4

\section{Adsorption and decomposition of ethanol on supported Au catalysts}

Gazsi, A.; Koos, A.; Bansagi, T.

Catalysis Today 160 (2011) 70.

MTMT azonosító: 1422942

IF.: 3,407

Független hiv.: 17

Függő hiv.: 3

Production of hydrogen from dimethyl ether on supported Au catalysts

Gazsi, A.; Ugrai, I.; Solymosi, F.

Applied Catalysis A: General 391 (2011) 360.

MTMT azonosító: 1413930

IF.: 3,903

Független hiv.: 15

Függő hiv.: 3

Decomposition and Reforming of Formic Acid on Supported Au Catalysts: Production of CO-Free $\mathrm{H}_{2}$

Gazsi, A.; Bansagi, T.; Solymosi, F.

J. Phys. Chem. 115 (2011) 15459.

MTMT azonosító: 1680533

IF.: 4,805

Független hiv.: 18

Függő hiv.: 6 
A Ph.D. értekezéshez nem kapcsolódó publikációk

Decomposition and reforming of methanol on Pt metals supported by carbon Norit

Tolmacsov, P.; Gazsi, A.; Solymosi, F.

Applied Catalysis A: General 362 (2009) 58.

MTMT azonosító: 113800

IF.: 3,564

Független hiv.: 13

Függő hiv.: -

A Comparative Study of the Decomposition of Ethanol on Pt Metals Supported by

\section{Carbon}

Gazsi, A.; Tolmacsov, P.; Solymosi, F.

Catal Lett.130 (2009) 386.

MTMT azonosító: 1241673

IF.: 2,021

Független hiv.: 4

Függő hiv.: 2

Photocatalytic decomposition of formic acid and methyl formate on $\mathrm{TiO}_{2}$ doped with $\mathrm{N}$ and promoted with Au. Production of $\mathrm{H}_{2}$

Gazsi, A.; Schubert, G.; Pusztai, P.; Solymosi, F.

J. Hydrogen Energy 38 (2013) 7756.

MTMT azonosító: 2399301

IF.: 2,930

Független hiv.: 3

Függö hiv.: 3

Photocatalytic decomposition of methanol and ethanol on Au supported by pure or Ndoped $\mathrm{TiO}_{2}$

Gazsi, A.; Schubert, G,; Bansagi, T.; Solymosi, F.

Journal of Photochemistry and Photobiology A: Chemistry 271 (2013) 45.

MTMT azonosító: 2399279

IF.: 2,291

Független hiv:: -

Függő hiv.: 1 
Photocatalytic decomposition and oxidation of dimethyl ether over $\mathrm{Au} / \mathrm{TiO}_{2}$

G. Schubert, A. Gazsi, F. Solymosi

Journal of Catalysis 313 (2014) 127-134

MTMT azonosító: 2577685

IF: 6,073

Független hiv.: -

Függő hiv.: -

A közlemények összesített impakt faktora: 31,015

Független hivatkozások száma: 83

Függő hivatkozások száma: 22 
A Ph.D. értekezéshez kapcsolódó elöadások

Metanol bomlásának vizsgálata különböző hordozós Au katalizátorokon

Gazsi A.

Kémiai Előadói Napok

Szeged, 2010.

Preparation of carbides effective for the production of $\mathrm{CO}$-free $\mathrm{H}_{2}$

Solymosi F.; Gazsi A.;

$17^{\text {th }}$ International Symposium on the Reactivity of Solids

Bordeaux, 2011.

A Ph.D. értekezéshez nem kapcsolódó elöadások, poszterek

Poszter: Hydrogenation activity of Pt/SBA-15 catalysts in the conversion of cyclohexene to cyclohexane

Rémiás R.; Gazsi A.;Molnár É.; Tóth T.; Kukovecz Á.; Kónya Z.; Kiricsi I.

Pannon Konferencia

Szeged, 2006

Photodecomposition of formic acid on N-doped and Au-promoted $\mathrm{TiO}_{2}$. Production of CO-free $\mathrm{H}_{2}$

Solymosi F.; Gazsi A.;

$10^{\text {th }}$ Natural Gas Conversion Symposium

Doha, 2013.

Poszter: Production of CO-free hydrogen in photocatalytic reactions

Solymosi F.; Gazsi A.;

Gordon Research Conferences, Chemical Reactions at Surfaces

Les Diablerets,

Svájc, 2013. 


\section{Köszönetnyilvánítás}

Köszönettel tartozom témavezetőmnek, Prof. Solymosi Frigyes akadémikusnak, aki biztosította, hogy kutatásaimat az MTA Reakciókinetikai Kutatólaboratóriumban végezhettem, valamint ösztönzéséért és szakmai támogatásáért, amellyel mindvégig segítette munkámat.

Köszönöm Ugrai Imrének az IR mérések valamint Koós Ákosnak az XPS mérések elvégzését.

Hálás vagyok valamennyi munkatársamnak, akik munkájukkal és tanácsaikkal rengeteg segítséget nyújtottak a dolgozat megszületésében, és azért hogy kellemes munkahelyi légkörben dolgozhattunk együtt az elmúlt években.

Külön köszönet illeti édesanyámat a kitartó támogatásáért és belém vetett bizalmáért. 